WHC-EP- -0348

DE9 1001284

\title{
Hanford Site Waste \\ Management and \\ Environmental Restoration \\ Integration Plan
}

D. L. Merrick

Date Published

April 30, 1990

Prepared for the U.S. Department of Energy

Assistant Secretary for Environmental Restoration and Waste Management

Westinghouse
W.O. Box 1970

Hanford Operations and Engineering Contractor for the

U.S. Department of Energy under Contract DE-AC06-87RL10930 
WHC-EP-0348

\section{ACKNOWLEDGMENT}

Invaluable guidance on the structure and contents of this plan was received from the original committee designated to overview the preparation: Steve Slate of Pacific Northwest Laboratory (PNL) and Becky Austin, Cherri DeFigh-Price, Dave Turner, and Don Wodrich of Westinghouse Hanford Company (Westinghouse Hanford). The preparation of the activity networks required a determined and persistent effort by Carol Fow of PNL, Project Manager of the work task; Bryan Giesler of PNL who performed the computerized development of the logic diagrams; and Dallas Hoover of Westinghouse Hanford who facilitated the reviews.

Contributors to the double-shell tank waste networks included Paul Scott. of PNL and John Appel, Ron Claghorn, Leslie Stegen, and Bob Watrous of Westinghouse Hanford. Contributors to the single-shell tank waste networks included Bob Wegeng and Jim Creer of PNL and Tony DiLiberto and Mike Klem of Westinghouse Hanford. Gene Reep of Westinghouse Hanford contributed to the encapsulated cesium and strontium networks. Contributors to the solid waste networks included Darrel Duncan and Jerry scott of Westinghouse Hanford. Contributors to the past practice units networks included Roy Gephart of PNL and Rich Gerth of Westinghouse Hanford. Mike Hughes of Westinghouse Hanford contributed to the surplus facilities networks. 
Document Title: Hanford Site Waste Management and Environmental Restoration Integration Plan

Prepared by:

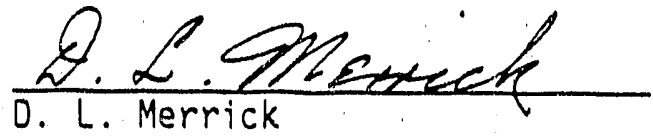
Westinghouse Hanford Company

$\frac{4 \cdot 27 \cdot 90}{\text { Date }}$

Assisted by:

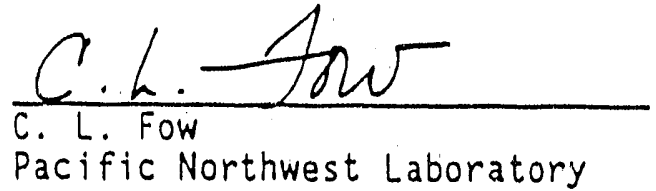

$\frac{4 \cdot 27 \cdot 90}{\text { Date }}$

Overview Committee for this Document:

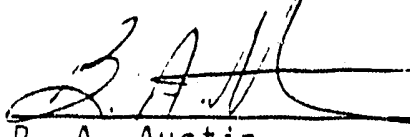

B. A. Aust in Westinghouse Hanford Company

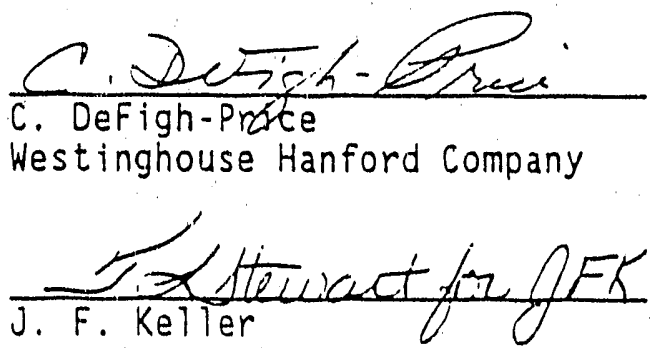
Pacific Northwest Laboratory

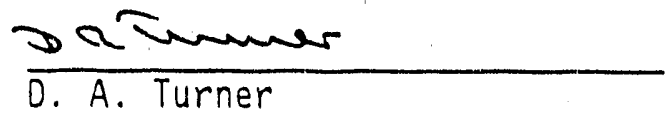
Westinghouse Hanford Company

DDenonid. D. D. Wodrich Westinghouse Hanford Company

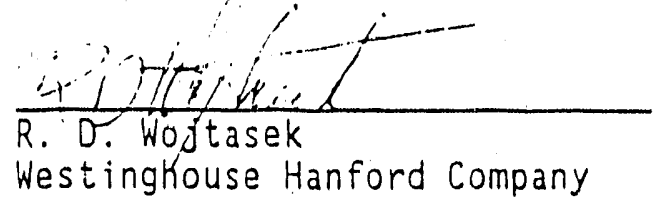

$\frac{4 / 30 / 90}{\text { date }}$

$\frac{4-27-90}{\text { Date }}$

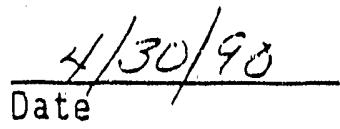
$\frac{4 / 30 / 90}{\text { Date }}$ $\frac{4 / 30 / 90}{\text { Date }}$ $\frac{y}{\text { Date }}$

$$
i+i / i v
$$


WHC-EP-0348

\section{EXECUTIVE SUMMARY}

The "Hanford Site Waste Management and Environmental Restoration Integration Plan" describes major actions leading to waste disposal and site remediation. The primary purpose of this document is to provide a management tool for use by executives who need to quickly comprehend the waste management and environmental restoration programs.

The two programs are divided into seven missions and a general category called activity support. The major actions associated with each of the seven missions are illustrated in diagrams referred to as activity networks. Where necessary, there are flowcharts and tabular data. These collective illustrations are supported with a minimum amount of text.

This plan provides only a brief representation of schedules and budget forecasts. It does not discuss programmatic concerns such as baselines, change control, and work breakdown structures. While this plan provides no more than a cursory view of the regulatory requirements and compliance activities, it is recognized that progress can only be made with full concurrence from the regulatory authorities. Administrative and regulatory information can be found in other publications that are concerned with more near-term activities. In this regard, this plan uniquely shows whit needs to be done (in contrast to how, when, and why) with less emphasis on administrative and regulatory concerns. 
The principal value of this plan is that it can be used to embark on more detailed analyses of certain integrating features. For example, tabular representations are made to show (1) how technology development can be integrated among the missions, and (2) how facilities (existing or planned) can be utilized fur multiple missions. Another value is that it explains the overall waste disposal and remedial action effort in a manner that is easily comprehended by those outside the U.S. Department of Energy system such as federal- and state-agency personnel and congressional committee members.

The first section of this plan provides a summary overview of the seven missions. It is followed by introductory material and then an overview of each of the seven missions. 
WHC-EP-0348

\section{CONTENTS}

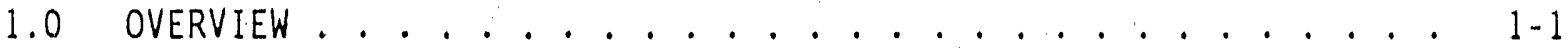

1.1 WASTE MANAGEMENT ................. 1 . .

1.2 ENVIRONMENTAL RESTORATION . . . . . . . . . . . 1.9

1.3 SUPPORTING ACTIVITIES . . . . . . . . . . . . . 1-10

1.4 TECHNOLOGY DEVELOPMENT . . . . . . . . . . 1-10

1.5 SUMMARY SCHEDULE AND BUDGET FORECAST . . . . . . . 1-10

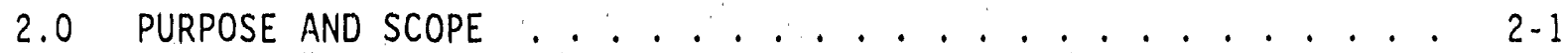

2.1 THE FEATURES AND LEVELS OF ACTIVITY NETWORKS ...... 2-1

2.2 KEY ASSUMPTIONS ......... 2-2

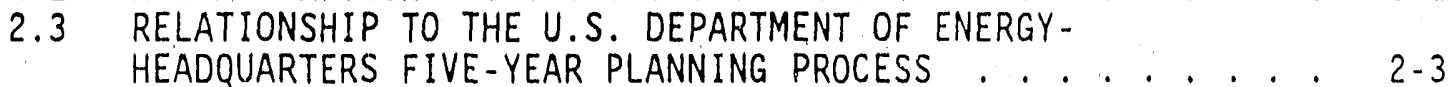

3.0 INTEGRATING FEATURES OF THE MISSIONS $\ldots \ldots \ldots \ldots \ldots \ldots$

3.1 TECHNOLOGY INTEGRATION ................. $3-1$

3.1.1 Characterization ............. 3-1

3.1.2 Waste Retrieval ............. 3-4

3.1 .3 Processing and Treatment ......... 3-. 3

3.1 .4 Waste Disposal . . . . . . . . . . . 3-6

3.2 TREATMENT, STORAGE, AND DISPOSAL FACILITIES .... . . 3-6

4.0 DOUBLE-SHELL TANK WASTES .................... . . . . . .

4.1 INTERIM STORAGE AND SURVEILLANCE ............... 4 - .

4.2 TREATMENT AND DISPOSAL . . . . . . . . . . . 4.2

4.3 ACTIVITY NETWORK . . . . . . . . . . . . . . . . 4-4

5.0 SINGLE-SHELL TANK WASTES . . . . . . . . . . . 5-1

5.1 INTERIM STORAGE AND SURVEILLANCE ......... 5-1

5.2 CHARACTERIZATION, DEVELOPMENT, AND DEMONSTRATION.... $5-2$

5.3 ACTIVITY NETWORK . . . . . . . . . . . . . . 5-3

6.0 ENCAPSULATED RADIOCESIUM AND RADIOSTRONTIUM ......... 6-1

6.1 INTERIM STORAGE AND SURVEILLANCE .......... $6-1$

6.2 TREATMENT AND DISPOSAL .............. $6-1$

6.3 ACTIVITY NETWORK . . . . . . . . . . . . . . . . . . . 6-1

7.0 SOLID WASTES . . . . . . . . . . . . . . . . 7-1

7.1 INTERIM STCRAGE AND SURVEILLANCE .......... . 7-1

7.1.1 Transuranic Wastes ............ 7-1

7.1.2 Low-Level Waste, Nonhazardous ....... 7-2

7.1.3 Low-Level Waste, Mixed . . ...... . . . . . 7-2

7.1.4 Hazardous Waste, Nonradioactive . . . . . . . 7-3

7.2 TREATMENT AND DISPOSAL ............. . . 7-3

7.3 ACTIVITY NETWORKS . . . . . . . . . . . . . . 7-5

8.0 LIQUID EFFLUENTS . . . . . . . . . . . . . . . . . . 8.1

8.1 PLANS TO DISCONTINUE CONTAMINANT DISCHARGES ..... . 8 - .

8.2 ACTIVITY NETWORK . . . . . . . . . . . . 8-1 
CONTENTS (continued)

9.0 PAST PRACTICE UNITS . . . . . . . . . . . . 9.1

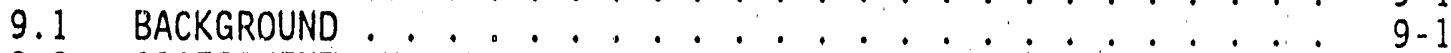

9.2 ASSESSMENT AND CHARACTERIZATION ........ 9-1

9.2.1 Preliminary Assessment and Site Inspection... . 9-3

9.2.2 Investigations and Studies ........ 9-4

9.2.3 Environmental Restoration Remedial Actions

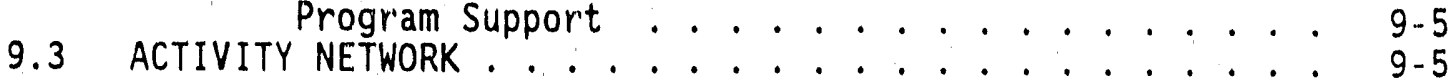

10.0 DECONTAMINATION AND DECOMMISSIONING OF SURPLUS FACILITIES . . 10-1

10.1 HANFORD SITE SURPLUS FACILITIES ........ 10-1

10.1.1 Surveillance and Maintenance . . . . . . 10-1

10.1.2 Surplus Reactors ........ $10-2$

10.1.3 Other Surplus Facilities......... 10.2

10.2 ACTIVITY NETWORK . . . . . . . . . . . . 10-2

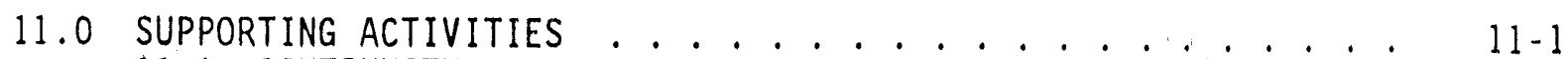

11.1 CONTINUITY OF OPERATION $\ldots 11-1$

11.2 NATIONAL ENVIRONMENTAL POLICY ACT ACTIONS ..... 11.1

11.3 CORRECTIVE ACTIVITIES .............. $11-4$

11.4 WASTE MINIMIZATION . . . . ............. . . . $11-5$

11.5 LABORATORY SUPPORT . . . . . . . . . . $11-5$

11.6 ENVIRONMENTAL MONITORING AND CONTROL . . . . $11-6$

12.0 REFERENCES . . . . . . . . . . . . . . $12-1$ 


\section{LIST OF FIGURES}

1-1 Waste Disposal and Site Remediation ........... 1-3

1-2 Summary Activity Network. . . . . . . . . . . . . . . . . 1-5

1-3 Summary Schedule for Waste Disposal and Site Remediation, Emphasizing Tri-Party Agreement Milestones.......... 1-11

4-1 Treatment and Disposal of Double-Shell Tank Wastes...... . 4-3

4-2 Level 1 Activity Network for the Double-Shell Tank Wastes . . . 4-5

5-1 Level 1 Activity Network for the Single-Shell Tank Wastes . . . 5-5

6-1. Level 1 Activity Network For Encapsulated Cesium and Strontium : 6-3

7-1 Solid Waste Flowchart .. . . . . . . . . . . . . 7-4

7-2 Level 1 Activity Network for Solid Waste Logic Diagram . . . . . 7-7

8-1 Liquid Effluent Alternative Treatment and Disposal System . . 8-3

8-2 Level 1 Activity Network for Liquid Effluerit Streams... . . . 8-5

9-1 Level 1 Activity Network for Past Practice Units . . . . . . . . 9-7

10-1 Level 1 Activity Network for Surplus Facilities....... . 10-3

11-1 National Environmental Policy Act Determination Process . . . 11-2

\section{LIST OF TABLES}

1-1 Waste Management Mission Inventories............. 1-7

1-2 Budget Forecast Through Fiscal Year 1996............ . 1-13

3-1 Technology Issues Matrix.................. 3-2

3-2 Treatment, Storage, and Disposal Facilities . . . . . . . 3-7

4-1 Double-Shell Tank Capacities.............. . . . . $4-1$

8-1 Liquid Effluent Streams . . . . . . . . . . . . . . . . 8-2

9-1 Hanford Site Environmental Restoration Remedial Actions

Program Operable Units Listing . . . . . . . . . . . . . 9-2 


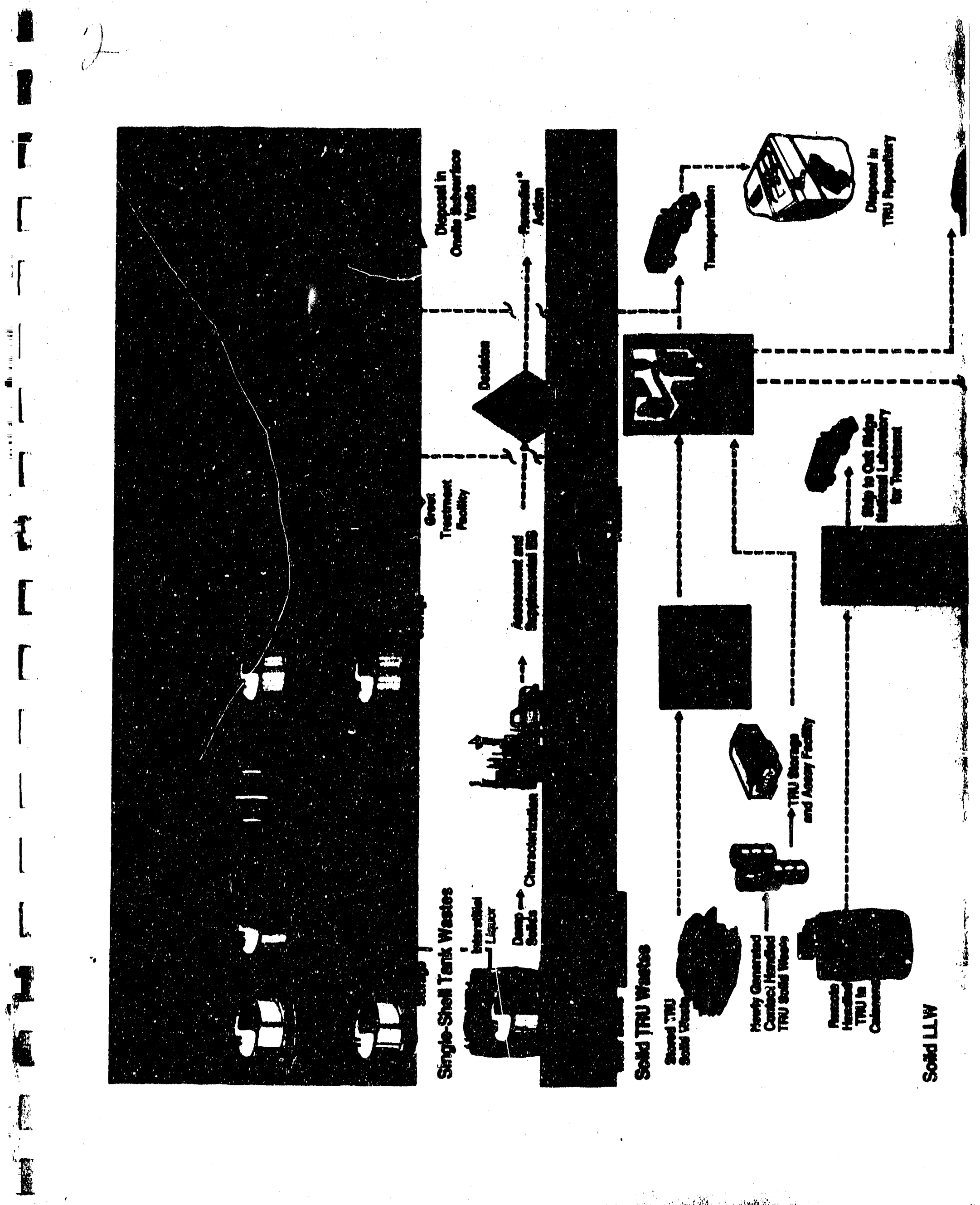




\section{LIST OF TERMS}

CERCLA

\section{D\&D \\ DOE \\ EA \\ DST \\ Ecology \\ EIS \\ EPA \\ ERRA \\ FFTF \\ FY \\ HOW-EIS}

HEPA

HLW

$\mathrm{HQ}$

HW

HWMP

HWVP

LLW

MW

NEPA

OU

PFP

PNL

PPU

PRF

PSW

PUREX

QA

$R \& D$

RCRA

RDDT\&E

RFI/CMS

$\mathrm{RI} / \mathrm{FS}$

ROD

SARA

SST

Technology Plan

TD\&D

Tri-Party Agreement

TRU

TSO
Comprehensive Environmental Response, Compensation, and Liabllity Act decontamination and decommissioning U.S. Department of Energy Environmenta1 Assessment double-shell tank Washington State Department of Ecology environmental impact statement

U.S. Environmental Protection Agency

Environmental Restoration Remedial Actions Fast Flux Test Facility

fiscal year

Hanford Defense Waste Environmental Impact Statement

high-efficiericy particulate air

high-level waste

DOE-Headquarters

hazardous waste

Hanford Waste Management Plan

Hanford Waste Vitriftcation Plant

low-level waste

mixed waste

National Environmental Policy Act operable unit

Plutonium Finishing Plant

Pacific Northwest Laboratory

past practice unit

Plutonium Reclamation Facility

phosphate-sulfate waste

Plutonium-Uranium Extraction Plant.

quality assurance

research and development

Resource Conservation and Recovery Act

research, development, demonstration, testing, and evaluation

RCRA Facility Investigations/Corrective Measure Study

Remedial Investigations/Feasibility

Studies

record of decision

Superfund Amendment Reauthorization Act single-shell tank

Environmental Restoration and Waste

Management Technology Plan

Technology Development and Demonstration

Hanford Federal Facility Agreement and

Consent Order

transuranic

treatment, storage, and disposal 


\section{LIST OF TERMS (continued)}

WAC

West inghouse Hanford WIPP

WRAP
Washington Administration Code Westinghouse Hanford Company Waste Isolation Pflot Plant Waste Receiving and Processing 
WHC -EP -0348

\section{HANFORD SITE WASTE MANAGEMENT AND ENVIRONMENTAL RESTORATION INTEGRATION PLAN}

\subsection{OVERVIEW}

This Hanford Site Waste Management And Environmental Restoration Integration Plan describes actions leading to the disposal of all radioactive and hazardous waste and the remediation of inactive sites and facilities. The Waste Management and Environmental Restoration Programs have been divided into missions.

Waste Management consists of five missions: (1) double-shell tank (DST) wastes; (2) single-shell tank (SST) wastes (surveillance and interim. storage, stabilization, and isolation); (3) encapsulated cesium and strontium; (4) solid wastes; and (5) liquid rffluents. Environmental Restoration consists of two missions: past 1 ...uce units (PPU) (including characterization and assessment of SST wastes) and surplus facilities. For convenience, both aspects of SST wastes are discussed in one place. A general category of supporting activities is also included.

Figure 1-1 shows the major activities for each mission. Figure 1-2 is a summary activity network emphasizing interactions among these missions.

An extensive technology research, development, demonstration, testing, and evaluation (RDDT\&E) effort is under way. Emphasis is being placed on research and development, for those missions where there is uncertainty with the technology to be implemented, and also on demonstration, testing, and evaluation for those missions where the technology to be implemented is well developed.

The planning baseline inclildes the key milestone dates set in the Hanford Federal Facility Agreement and Consent Order (Tri-Party Agreement) negotiated in 1989 between the U.S. Department of Energy (DOE), the U.S. Environmental Protection Agency (EPA), and the Washington $S^{+}$ate Department of Ecology (Ecology).

\subsection{WASTE MANAGEMENT}

The quantities shown in Table 1-1 are associated with each of the waste management missions. Although the risk-related radioactivity is shown here, $i 1$. is known that many of the wastes contain hazardous chemicals and these wastes will need to be dealt with as mixed waste. Because the hazardous content is not well defined, only radioactivity is shown.

$$
1-1 / 1-2
$$


DOUBLE-SHELL

$\equiv$

$=$

=

$=$

$=$

$=$

$-$

$=$

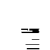

$=$

$\overline{\bar{z}}$

$=$

$=$

言

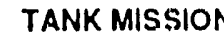

\section{TANK MISSION}

SINGLE-SHELL TANK MISSION

I

$=$

二

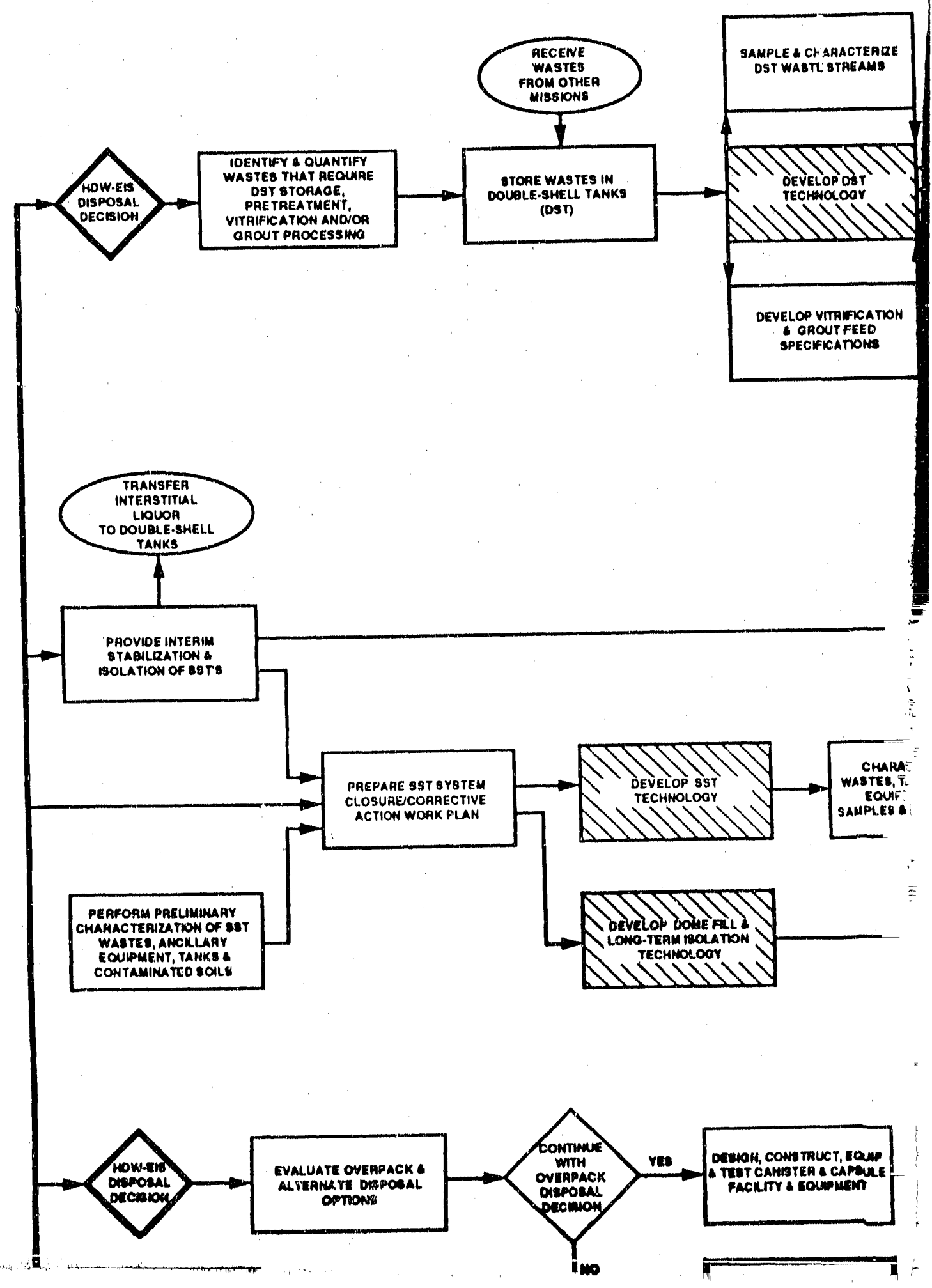




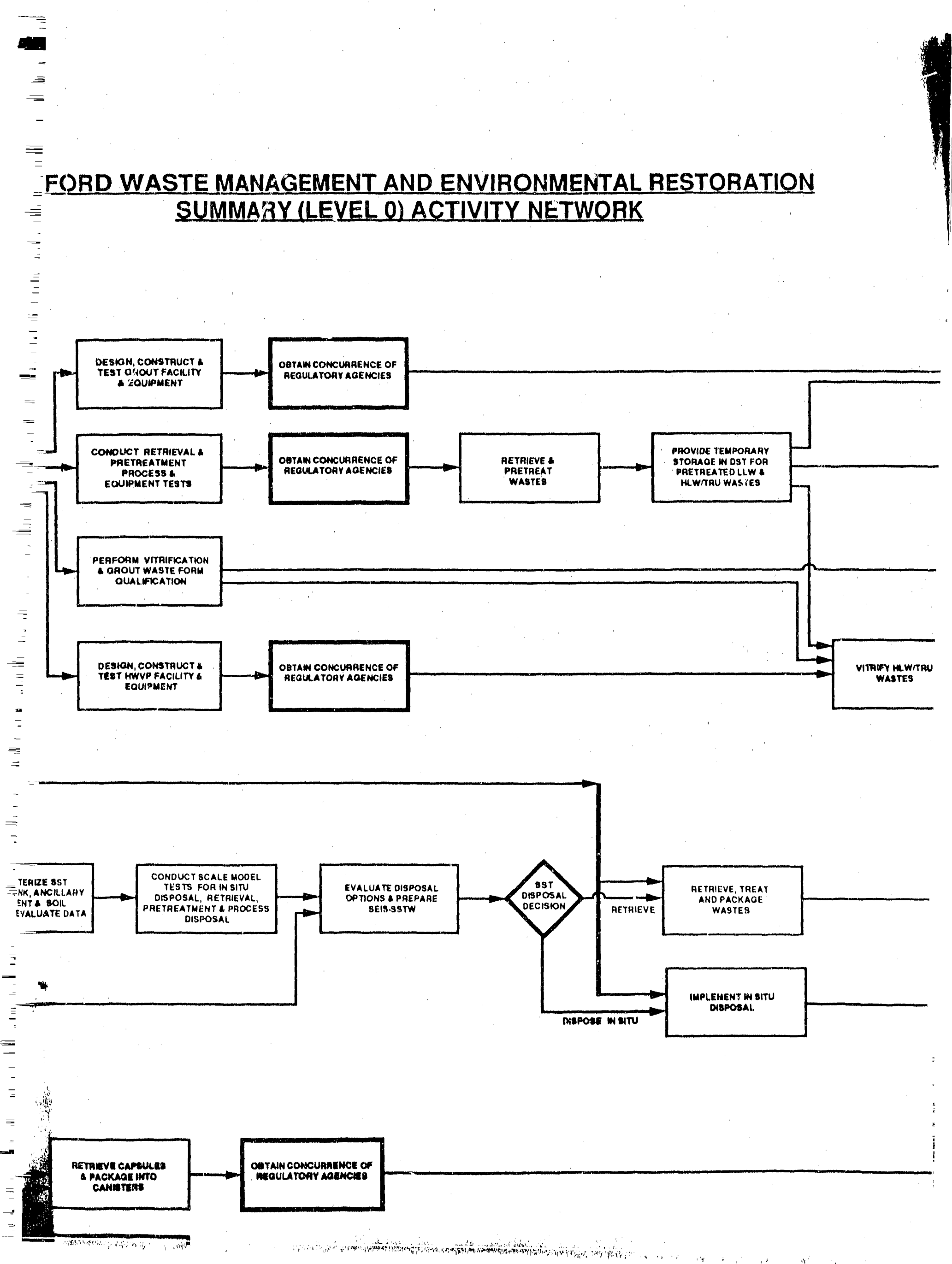


$=$

$$
\text { 辛 }
$$

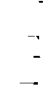

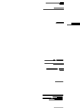

$=$

$\overline{\overline{\underline{E}}}$

$=$

$=$

-
-
$=$

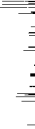

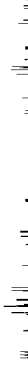

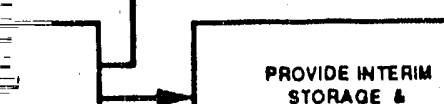

PAOCESS LLW A

PAETREATEDLLW

INTO QROUT

STORAOE

SHAP YO AEPOSITOAY

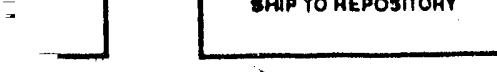

三

$=$

$=$

$\overline{-}$

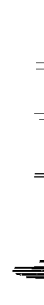

$=$
$=$
$=$
$=$
$=$
$=$
$=$
$=$
$=$
$=$
$=$
$=$
$=$
$=$
$=$
$=$

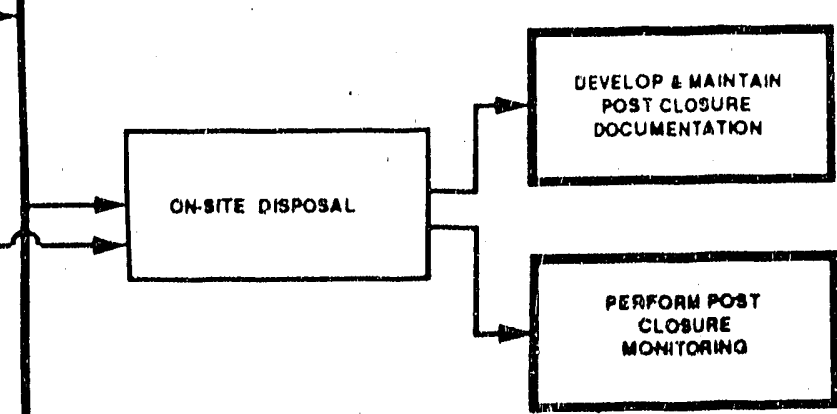

$\equiv$

$=$

$=$

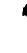




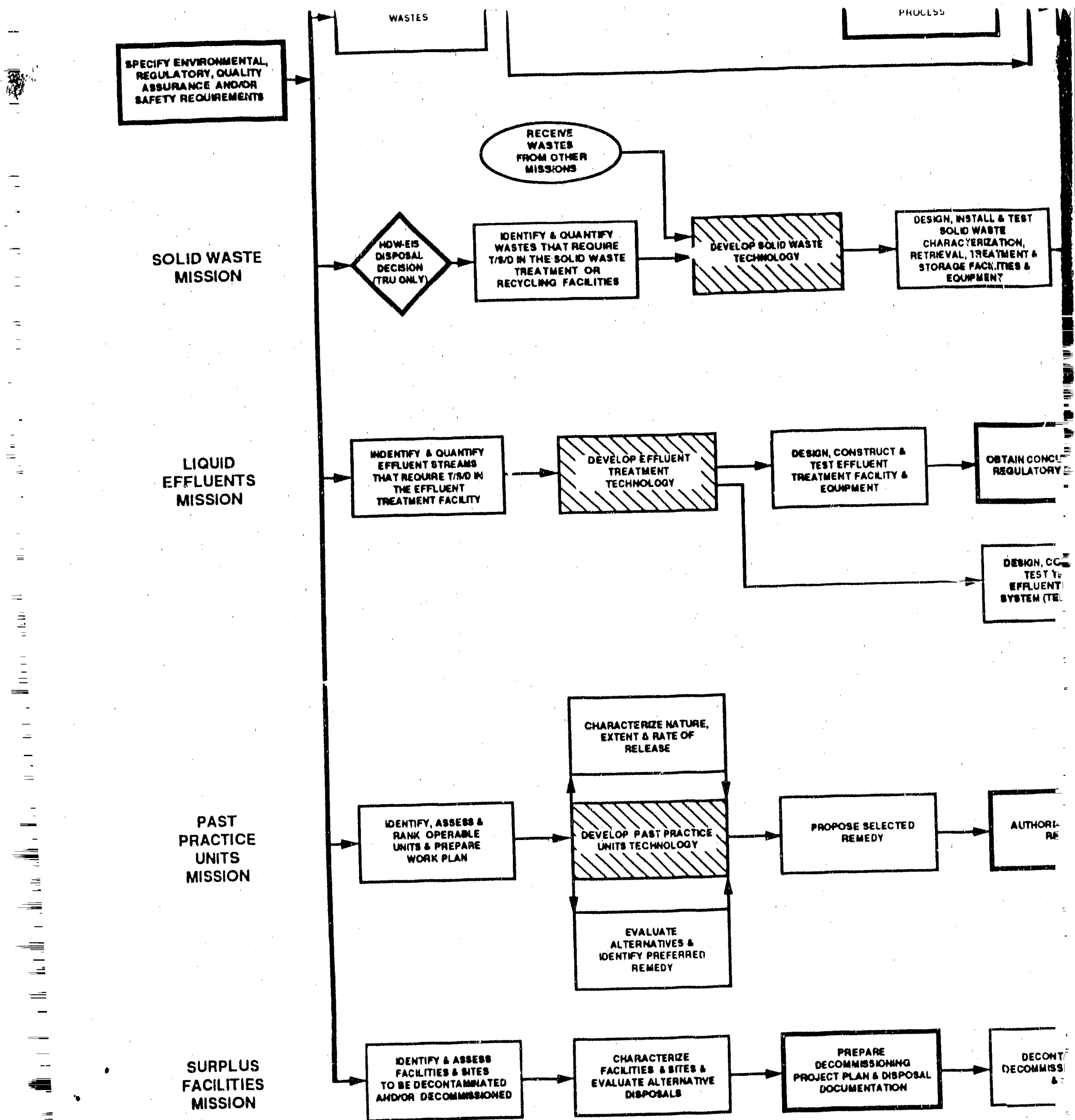


$=$

$=$

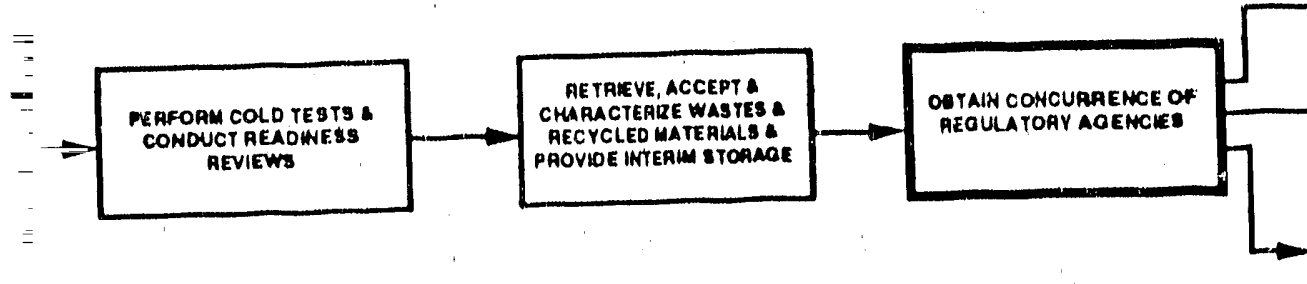

COMVET AECYCLLD

TO UAE

$=$

$-$

$=$

三

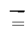

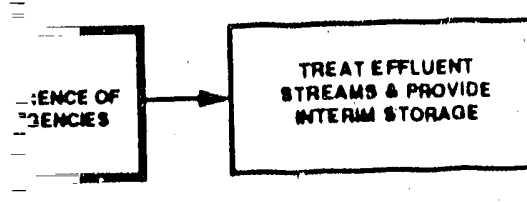

$$
\equiv
$$$$
=
$$

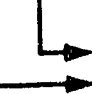

PAOCESS WASTE STAEAU

W TAEATED EFFLUENT

DISPOOSAL SYSTEM (TEDS)

$$
\text { FACuMY }
$$

$=$

$=$

$=$

$=$$$
\stackrel{-1}{=}
$$$$
\stackrel{-1}{=}
$$$$
\overline{-}
$$

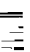$$
=
$$$$
\overline{\overline{-}}
$$

(1)

$=$

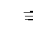

= ATE 4

=icatru

言

三

플

$=$

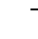

$\equiv$
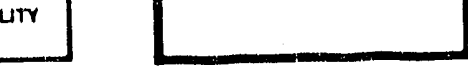

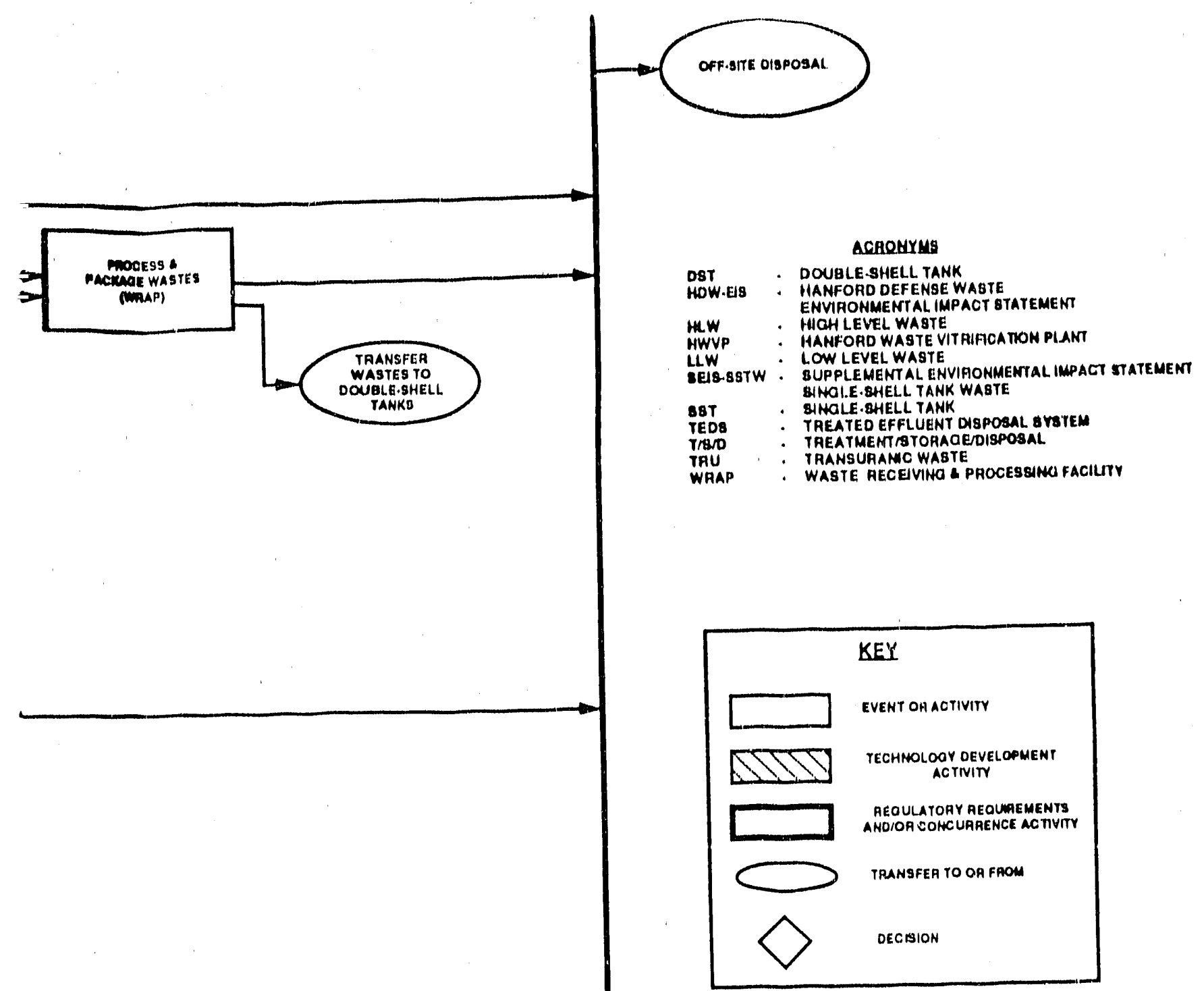

PNLPHSD:B OLESLERVAM

APALL 27,1000
HWO AFV O

Figure 1.2 Summary Activity Network 
WHC-EP-0348

Table 1-1. Waste Management Mission Inventortes.

\begin{tabular}{lccc}
\hline Waste type & $\begin{array}{c}\text { Stored waste } \\
\text { activity }(M C 1)\end{array}$ & $\begin{array}{c}\text { Stored waste } \\
\text { inventory }\left(\mathrm{m}^{3}\right)\end{array}$ & $\begin{array}{c}\text { Projected } \\
\text { recetpts }\left(\mathrm{m}^{3}\right)\end{array}$ \\
$\begin{array}{l}\text { Double-she11 tank } \\
\text { wastes }\end{array}$ & 111 & 78,000 & 30,000 \\
$\begin{array}{l}\text { Single-she11 tank } \\
\text { wastes }\end{array}$ & $157^{\mathrm{a}}$ & $139,000^{\mathrm{a}}$ & None \\
$\begin{array}{l}\text { Encapsulated radiocestum } \\
\text { and radiostrontium }\end{array}$ & $121^{\mathrm{b}}$ & 2 & None \\
Solid transuranic wastes & $56^{\mathrm{b}}$ & 1 & None \\
Solid low-level wastes & $<1$ & 10,000 & 4,000 \\
Radioactive mixed wastos & 9.5 & $552,000 \mathrm{C}$ & 350,000 \\
Hazardous wastes & 0.7 & 1,800 & 10,100 \\
L.tquid effluents & - & None & Not projected \\
\hline
\end{tabular}

aThis includes $26,800 \mathrm{~m}^{3}$ of interstitial liquid contained within the pores of the salticake and sludge.

bincludes activity resulting from daughters.

cConsidered to be disposed.

dSmall volumes are accumulated and sent to commerctal disposal

facilities.

e 33 streams have contaminant discharges: 19 to be corrected by fiscal year 1995 and 14 thereafter.

The DST wastes from past and ongoing operations are stored in 28 underground storage tanks, each with a nominal capacities of $3,800 \mathrm{~m}^{3}$ (one million gallons) or $4,300 \mathrm{~m}^{3}$. The treatment and disposal activities have been defined and are projected to require 20 yr for completion. Retrieval of the DST wastes, the pretreatment to meet regulatory requirements at the 244-AR Vault and B Plant, followed by treatment at the Grout Treatment. Facility and the Hanford Waste Vitrification Plant, form the key operations leading to disposal. Technology associated with these key operations has progressed to demonstration, testing, and evaluation.

The 244-AR Vault and B Plant are being readted for a pretreatment demonstration by October 1993 to separate the waste streams into high-level waste (HLW), transuranic (TRU) waste, and low-level waste (LLW) fractions. The Grout Treatment Facility, where the LLW and the LLW fraction from pretreatment is converted into grout, has undergone a full-scale demonstration with nonhazardous LLW and will accept the hazardous LLW streams as they are prepared. The Hanford Waste Vitriftcation Plant will immobilize the HLW fraction in glass. 
Design is progressing on the Hanford Waste Vitrification Plant in support of construction startup in July 1991, and hot operations are scheduled for December 1999. As currently projected, the disposable quantities will include 1,460 vitrified glass canisters $\left(0.62 \mathrm{~m}^{3}\right.$ each) of HLW for disposal in the HLW repository, 500 vitrified glass canisters of TRU waste for shipment to the Wiste Isolation iflot Plant (WIPP), and $233,000 \mathrm{~m}^{3}$ of grouted LLW for disposal in near-surface vaults.

The SST wastes from past operations are being stored in 149 underground storage tanks ranging in capacity from 210 (55 thousand gallons) to $3,800 \mathrm{~m}^{3}$. The wastes are in the form of porous saltcake and sludge containing liquid within the interstices of the solids. The portion of the interstitial liquids that drain into saltwells (i.e., well screens immersed in the solids) will be transfer'red to DSTs by September 1995. The corrective actions for the SST systems, scheduled for completion by fiscal year (FY) 2018, require additional development and evaluation. For the near-term, characterization and assessment are being undertaken in complitance with procedures based on the Resource Conservation and Recovery Act of 1976 (RCRA) (Public Law 94-580, 90 Stat. 2795, 42 USC 6901 et. seq.) regulations. Approximately 15 yr will be required to complete the assicsment, influenced by a significani RDDT\&E effort and concluding with the issuance of an environmental impact statement (EIS) and closure plan. Until the RCRA and EIS process yields a definttive record of decision (ROD), the plans for the chosen corrective actions are uncertain.

Encapsulated radiocesium (1,349 capsules) and radiostrontium (597 capsules) are contained in double-walled, metal cylinders that are each approximately $50 \mathrm{~cm}$ in length and $6 \mathrm{~cm}$ in diameter. Some capsules were leased for beneficlal uses. The leased capsules are being returned and will be stored with the others in water basins. The disposal plan involves treating the encapsulated waste, as necessary, to meet repository waste acceptance criteria and disposing of the waste in an HLW repository.

The solid wastes can be divided into four categories: retrievably stored and newly generated TRU waste; LLW (nonhazardous); mixed LLW, which is both radioact tve and hazardous; and hazardous waste, which is not radioactive. strategies and plans are being developed for these solid waste streams.

The retrievable TRU waste generated before 1985 is stored for future treatment. Most of the TRU waste generated since 1985 is being certified and stored until the Waste Isolation Pllot Plant is avallable to accept Hanford Site waste; the remainder will require treatment. The LLW (nonhazardous) is buried, onsite except for small quantities stored for treatment. The mixed LLW is stored for treatment and/or disposal, although a small amount of highactivity waste is buried onsite. The hazardous waste (nonradioactive) is sent to RCRA-permitted commercial disposal facilities. Many of these ongoing activities will be encompassed in the Hanford Central Waste Complex, which will include the Waste Receiving and Processing (WRAP) Facility. The 
WRAP factlity will provide the treatment requirements adr essed above. Operations will be initiated in two modules: September 996 and September 1999. The first module will provide sorting, packaging, inspection, and certification; the second module will provide treatment processes.

There are 33 contaminated 1 iquid effluerit streams that are currently discharged to the soil column. A commitment has been made to discontinue the use of soil columns to treat and retain suspended or dissolved contaminants from these 1 tquid effluents streams in favor of waste minimization, waste treatment, and engineered disposal of concentrated wastes. Each of the effluent streams will undergo a primary treatment step, identffied through a best avaflable technology (BAT), economically achievable evaluation, in which a secondary waste streim will be produced containing the removed contaminants. The WRAP will be used to treat these contaminants. To ensure that the streams meet all discharge requirements, additional treated effluent disposal systems after the primary treatment step are being evaluated. A milestone has been established to complete liquid effluent treatment facllities and upgrades for Phase I streams (higher priortty based on derived criteria) by June 1995.

\subsection{ENVIRONMENTAL RESTORATION}

The PPUs consist of approximately 1,100 individual units where radioactive and/or hazardous wastes are located, elther in solls or in surface or subsurface engineered structures. An extenstve effort is under way for the characterization and assessment of the 78 designated operable units (OU), a grouping of adjacent or nearby individual units that can or should have assessments and remedial actions performed together. The 149 SSTs and the nearby units consist of six OUs. Four OUs have been designated as groundwater OUs and are associated with four known groundwater contamination plumes. A strategy has been defined with the intent of completing the study phase for all OUs by FY 2005 and completing the remedial actions by FY 2018. For the first OUs that are being addressed, the study phase is being planned for FY 1991. Remedial actions will be initiated as soon as FY 1993. Characterization and assessment is being undertaken in compliance with either RCRA or the Comprehensive Environmental Response, Compensation and Liability Act of 1980, (CERCLA) (Public Law 95-510, 94 Stat. 2767, USC 9601 et. seq.). The process selected for each oU will be sufficiently comprehensive to satisfy the technical requirements of both statutory authorittes and the respective regulations. Existing technology will be used, if acceptable. New technology will be introduced as soon as it is avallable.

Surplus facilities are those structures containing contaminated equipment and structural components for which no future missions are planned. The decontamination and decommissioning of 22 radioactive facilitites and several nonradloactive faciltties is complete. Survelllance and maintenance of more than 100 radioactively contaminated facilities awaiting decontamination and decoinmissioning (D\&D) is ongoing. Several more facilities will become surplus in future years as their missions end. Three major D\&D projects are in 
progress: the 183-H solar basins cleanup, the 201-C strontium semiworks complex, and the 100 Area ancillary facilities. Several smaller projects were comple ad in FY 1989. The public comment period on the EIS for the D\&D of eight reactors in the 100 Areas was recently completed. The resulting ROD is scheduled for issuance in FY 1991.

\subsection{SUPPORTING ACTIVITIES}

Supporting activities are those that are common to each of the waste management missions and may influence or interact with the Environmental Restoration Program. Fir the purposes of this document, supporting activities have been divided into six areas: (1) continuity of operations, (2) Nationa? Environmental rolicy Act (NEPA) actions, (3) corrective activities, (4) waste minimization, (5) laboratory support, and (6) environmental monitoring and control.

\subsection{TECHNOLOGY DEVELOPMENT}

A new approach is being taken in managing technology development and identifying new technology. The lead responsibility for this new approach is at the DOE-Headquarters Office of Technology Development. There are two areas. In the first area, RDDT\&E technology initiatives are identified that will significantly improve the conduct of operations and reduce costs. The objective of these initiatives is to make needed new or adapted technologies avallable within approximately 5 yr as well as to begin initiatives that can be made avaliable within $5 \mathrm{yr}$. A technology is considered avallable if it has been independently evaluated in accordance with regulatory agencies for the specific use and found to be technically able to meet regulations.

The second area, the evaluation of mid-to long-term basic research for environmental restoration, focuses on new and innovative technologies for remediation of sites contaminated by past practices. These technologies are being conceptualized and may be avallable in a 5- to 20-yr period.

Additionaliy, the DOE-HQ Office of Technology Development has the responsibllity to plan, implement and coordinate the parts of RDDT\&E involving technology transfer and university participation.

\subsection{SUMMARY SCHEDULE AND BUDGET FORECAST}

Figure 1-3 provides a summary schedule for waste disposal and site remediation, emphasizing the milestones in the Tri-Party Agreement. Table 1-2 provides the budget forecast through FY 1996. Budget forecasts beyond this time period have not been developed. It is reasonable to expect the budget forecast to change in the outyears, FY 1992 through FY 1996, as the work effort becomes more clearly defined. 


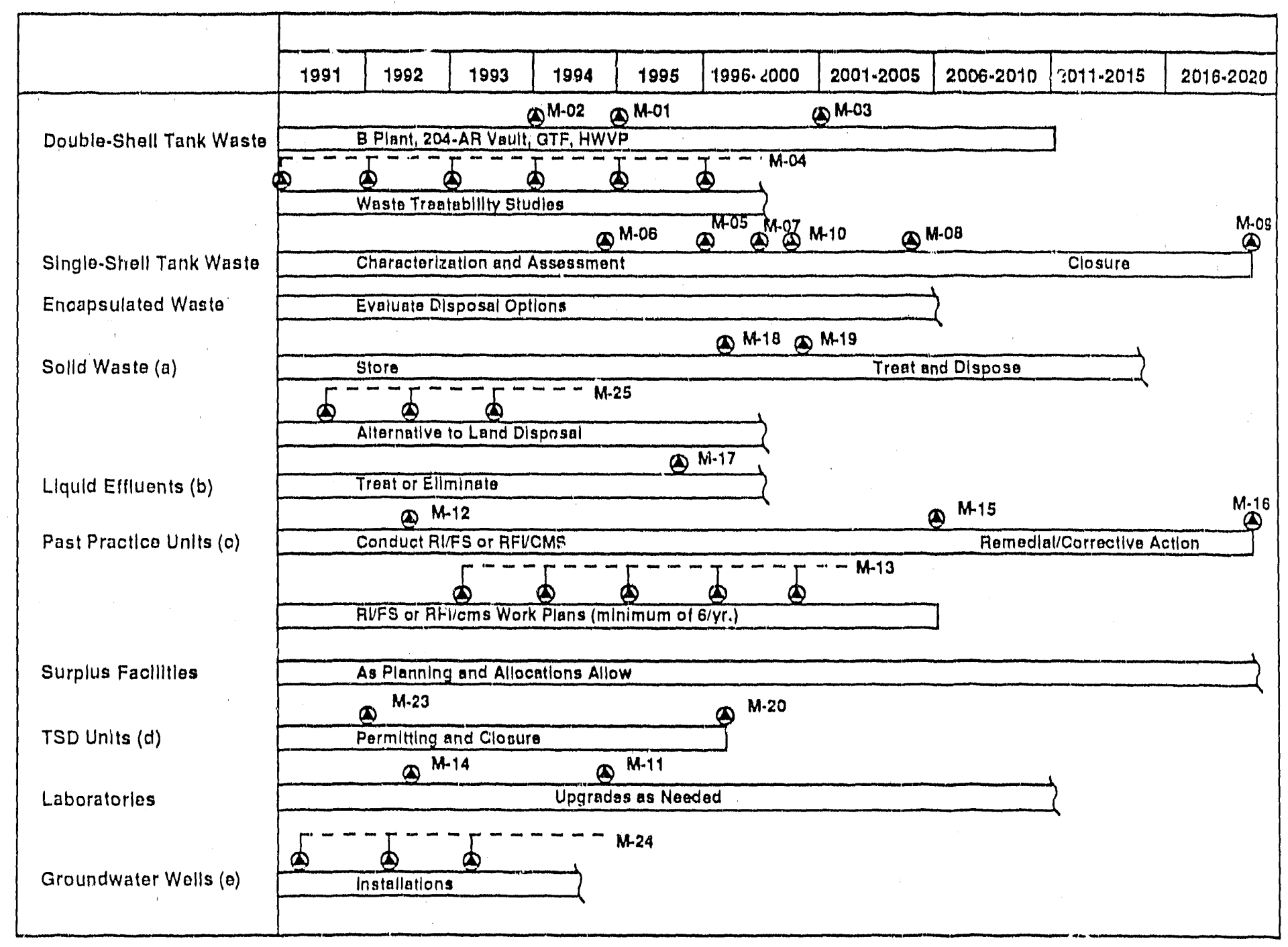

(a) All but a small fraction of the nonhazardous low-level waste is disposed and the high-activity, mixed low-level waste (drag is stored for offsite commerclal disposal.

(b) Treatment or ellmination of phase II streams will be completed after FY 1995.

(c) This category includes past practice units other than single-shell tank wastes. RI/FS refers to remedial investigation/feaslt measures study in RCRA regulations.

(d) These milestones are associated with permit and closure appllcatlons for treatment, storage and disposal (TSD) faclities lit

(e) This milestone specifles the rate of Installations as 29 in calendar year (CY) 1989 (Complete), 30 in CY 1990 and 50 at the en

(1) Most milestones shown here have subsets identlfled In the Tri-Party Agreement. 
M-01 Complete 14 grout campalgns and maintain currency thereafter

M-02 Inltlate B Plant operations for pretreatment

M-03 Inltiate Hanford Waste Vitriflcation Plant operations

M-04 Provide annual reports of tank waste treatabllity studies

M-05 Complete Interim stabllization

M-06 Develop retrleval technology and complete scale-model testing

M-07 Initiate full-scale demonstratlon of waste retrleval technology

M-08 Inltlate full-scale tank farm closure demonstration project

M-09 Compleie closure of all 149 tanks

M-10 Complete analyses of at least two complete core samples from each tank

$M-11$ Complete construction and Inltlate operations of expanded laboratory hot cells for high-level radloactlve mixed waste

M-12 Submit RI/FS or RFI/CMS work plans for 20 operable units

M-13 Submit s|X RI/FS or RFI/CMS process for all operable units

M-14 Complete construction and initiate operatlons of a low-level mlxed waste laboratory

M-15 Complete the RI/FS or RFI/CMS process for all operable unlts

$M-16$ Complete the remedial actions for all operable units

$\mathrm{M}-17$ Complete treatment facllitles/lupgrades for all phase I streams

M-18 Initlate operations of module $I$ of the Waste Recelving and Processing Facillity

M-19 Initlate operations of module II of the Waste Recelving and Processing Facillty

M-20 Submit Part B permit applications or closure plans for all RCRA TSD units

M-21 Submit RCRA interlm status compllance assessments for all TSD unlts (complete Aprll 1989)

M-22 Establish enforceable compliance action schedules (complete December 1989)
M-23 Achleve compliance with interim status requirements

M-24 Install RCRA groundwater monltoring wells untll all land disposal units are determined to have RCRA compllant monltoring systems

M-25 Provide annual reports of studies/efforts that are in progress to identlfy alternatives to land disposal of radioactlve mixed wastes

off) are burled In trenches per RCRA Interim status requlrements. The hazardous waste

Ility study In CERCLA regulations. RFI/CMS refers to RCRA facility Investigation/corrective compllance with Washington (State) Administrative Code (WAC) 173-303.

I of each $C Y$ thereafter untll requirements are met. 
Table 1-2. Budget Forecast Through Fiscal Year 1996.

\begin{tabular}{lrrrrrrrr}
\hline Category & \multicolumn{7}{c}{ Fiscal year (mil1tons of dollars) } \\
& $1990^{a}$ & \multicolumn{1}{c}{$1991^{\mathrm{b}}$} & $199 \mathrm{f}^{\mathrm{c}}$ & 1992 & 1993 & 1994 & 1995 & 1996 \\
\hline $\begin{array}{l}\text { Corrective } \\
\text { activities }\end{array}$ & 17.3 & 22.0 & 35.2 & 24.8 & 13.0 & 11.2 & 11.2 & 11.2 \\
$\begin{array}{c}\text { Waste } \\
\text { management }\end{array}$ & 338.3 & 499.7 & 637.9 & 1048.4 & 1086.2 & 1156.1 & 1063.7 & 896.2 \\
$\begin{array}{c}\text { Environmental } \\
\text { restoration }\end{array}$ & 84.4 & 101.8 & 205.2 & 226.0 & 281.0 & 343.4 & 381.6 & 414.2 \\
$\begin{array}{l}\text { Technology } \\
\text { development }\end{array}$ & 30.2 & 8.9 & 31.2 & 192.7 & 187.6 & 162.3 & 127.0 & 112.9 \\
\begin{tabular}{l} 
Total \\
\hline
\end{tabular} & 470.2 & 632.4 & 909.6 & 1491.9 & 1567.8 & 1673.0 & 1583.5 & 1434.5 \\
\hline
\end{tabular}

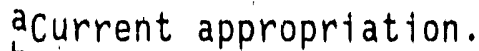

bpresident's budget.

CRequired funding to meet Tri-Party Agreement milestones. 
WHC - EP - 0348

\subsection{PURPOSE AND SCOPE}

This Hanford Site Waste Management and Environmental Restoration Integration Plan is an overview of the efforts required to dispose of radioactive waste and hazardous waste and to remediate PPUs and surplus facilities. Activity networks were selected as the central feature of this document because they provide a comprehensive illustration of each mission and an enduring baseline, generally unconstrained by budget and schedule changes. the primary purpose of this document is to provide a management tool for quickly comprehending the waste management and environmental restoration programs.

\subsection{THE FEATURES AND LEVELS OF ACTIVITY NETWORKS}

Activity networks feature a logical sequence of activities required to complete a complex task, such as the missions addressed in this document. Section 1.0 contains level zero networks for each mission, illustrating a minimum amount of detail.

The missions discussed in subsequent sections of this document include a Level 1 network that expands upon the network shown in Section 1.0. This expansion dissects each level zero activity into two or more Level 1 activities.

A supplement to this document (WHC-EP-0348 SUPP) includes Level 2 networks when that level of detail appeared appropriate. In like manner, a Level 1 activity is dissected into two or more Level 2 activities. For four of the missions (encapsulated radiocesium and radiostrontium, liquid effluents, PPUs, and the D\&D of surplus facilities) it does not appear iappropriate to expand upon the detail provided in the level l networks.

The activities associated with technoloyy are a prominent feature of the activity networks. The boxes containing technology activities are coded by cross-hatching.

It is important to note that technology as discussed in this document is consistent with the Hanford Site Environmental Restoration and Waste Management Technology Plan (Technology Plan) (WHC 1990). Because there are ro details on budget information in this document, no ittempt is made to distinguish between those technology activities that are funded by the recently established technology development budget category, EM 40, and those that are not. 
WHC -EP-0348

\subsection{KEY ASSUMPTIONS}

The key assumptions used in preparing this document include the following:

- The Waste Manaquement Program will provide facilities for the receipt and/or jisposal of liquid and solid radioactive, mixed, and hazardous waste.

- The $N$ Reactor will not restart and a new production reactor will not be constructed at the Hanford Site.

- Plutonium-Uranium Extraction (PUREX) Plant operations will cease in FY 1996 upon completion of the backlog of irradiated fuel from $N$ Reactor, the Shippingport Reartor: and the Fast Flux Test Facility (FFTF).

- The Plutonium Reclamation Facility (PRF) will continue operations through FY 1998.

- The Plutonium Finishing Plant (PFP) Remote Mechanical C Line will continue operations through FY 1994.

- The TRU extraction process will be in operation at PFP in FY 1993.

- The 244-AR Vault will be used for the sludge washing and settle/decant steps for the pretreatment of neutralized current acid waste. This processing step emerged as a result of studies in FY 1989 and did not appear in previous assumptions.

- B Plant will be used for the pretreatment of certain DST wast: to effect separation of HLW and TRU waste for feed to the Hanford Waste Vitrification Plant (HWVP) and LLW for feed to the Grout Treatment Facility.

- The neutralized current acid waste demonstration run at $244-A R$ Vault and B Plant will be started in October 1993. The demonstration supports the initiation of operations of HWVP in December 1999. The previously noted HWVP startup was the third quarter of FY 1999. Evaluations being undertaken at this writing may result in changes to the startup dates for the B Plant demonstration process and the HWVP operations.

- The Grout Treatment Facility will complete the processing of 14 campaigns by September 1994.

- All 149 SSTs will be interim stabilized and isolated by September 1996. 
- Certified TRU waste will be shipped to WIPP for disposal, but a date to initiate shipping has not been identified.

- The WRAP Facility will initiate operations in two phases: Module I in September 1996 and Module II in September 1999.

- The treated effluent disposal facility will initiate operations by June 1995 using best available technology, economically achievable to dispose of all Phase I end-of-pipe-treated effluent streams and some Phase II effluent streams.

- Ongoing facility compliance assessments will continue to identify deficiencies that need to be corrected.

- The Hanford Site schedules are based on receiving the required level shown in the budget forecast (the cost table is presented in Section 1.0).

There are new missions under consideration for the Hanford Site that could impact Waste Management. A significant impact to long-term operations (beyond $5 \mathrm{yr}$ ) would occur if an extended plutonium production mission and/or a new tritium mission is deployed. Other missions being considered, such as the production of $238 \mathrm{pu}$, would have a minor or insignificant impact.

\subsection{RELATIONSHIP TO THE U.S. DEPARTMENT OF ENERGY - HEADQUARTERS FIVE-YEAR PLANNING PROCESS}

Work at the Hanford Site is divided into seven missions to facilitate management; thus, the work breakdown structure is organized by these missions. The U.S. Department of Energy-Headquarters (DOE-HQ) has divided the work differently in preparing the Environmental Restoration and Waste Management Five-Year Plan, (DOE 1990). Budget categories of Waste Management Operations, Environmental Restoration, Technology Development, and Corrective Activities have been established. Corrective Activities are concerned with the immediate need to bring active and standby facilities into compliance with applicable regulations. In this document, Corrective Activities are addressed under Waste Management, Supporting Activities, as none of the identified Corrective Activities are associated with Environmental Restoration.

As further authorized by DOE-HQ, the Waste Manac?ment Operations activities have been categorized into six functional divisions:

- Waste minimization

- Waste treatment

- Waste storage

- Waste disposal

- Continuity of operations

- Applied research and development (R\&D). 
These divisions constitute budget and reporting categories for DOE-HQ submissions. This document does not selectively address these divisions.

The Hanford Site input for the annual, 5-yr planning cycle includes the preparation and submission of activity data sheets (DOE-RL 1989c) followed by a 5-yr site-specific plan (DOE-RL 1989a) describing the work to be done and reflecting the budgets and schedules in the activity data sheets. 


\subsection{INTEGRATING FEATURES OF THE MISSIONS}

\subsection{TECHNOLOGY INTEGRATION}

This section discusses the technology required to implement waste disposal and inactive site cleanup at the Hanford Site and the potential for integrating technology development among the missions. The matrix of technology issues presented in Table 3-1 illustrates the major areas where there is potential for integrating technology development among the missions. The integration of technology development can reduce costs and cleanup schedules by avoiding duplicate efforts. The following sections briefly describe the major goals and current status of the technology issues presented in Table 3-1. In addition, the technical issues with the strongest potential commonality between missions are discussed.

An in-depth analysis of the requirements of each mission for particular technology areas is required to determine the specific technology development activities that can be integrated. The requirements to be evaluated should include: (1) what the technology must do, (2) how well the technology must perform, and (3) how soon must the technology be available. The information from the requirements analysis also can be used to determine which technology being developed by the research, development, demonstration, testing, and evaluation program will apply at the Hanford Site.

A more detailed discussion of the technology issues at the Hanford Site can be found in the Hanford site Environmental Restoration and Waste Management Technology Plan (WHC 1990). The activity networks presented in Sections 4.0 through 10.0 of this plan, are useful for determining how the technology activities fit into the network of activities required by each mission to complete their objective. In the future, the Technology Development section of the DOE-HQ PIan may be a useful reference for understanding the specific technology needs at the Hanford Site and at other DOE sites (DOE 1990).

\subsubsection{Characterization}

Accurate and statistically representative characterization data are paramount to the development of retrieval and treatment processes and technology necessary to achieve the cleanup goals at the Hanford Site. Inaccurate or insufficient data can result in the development of inadequate or irrelevant technology. Current characterization technology is, in general, expensive, slow, and in some cases incapable of accurately detecting several hazardous and radioactive constituents at concentration levels specified by state and federal regulations. New characterization technology or improvements to existing technology are needed to reduce costs, minimize worker exposure, accelerate cleanup schedules, and improve compliance with state and federal regulations. 
Table 3-1. Technology Issues Matrix. (sheet 1 of 2)

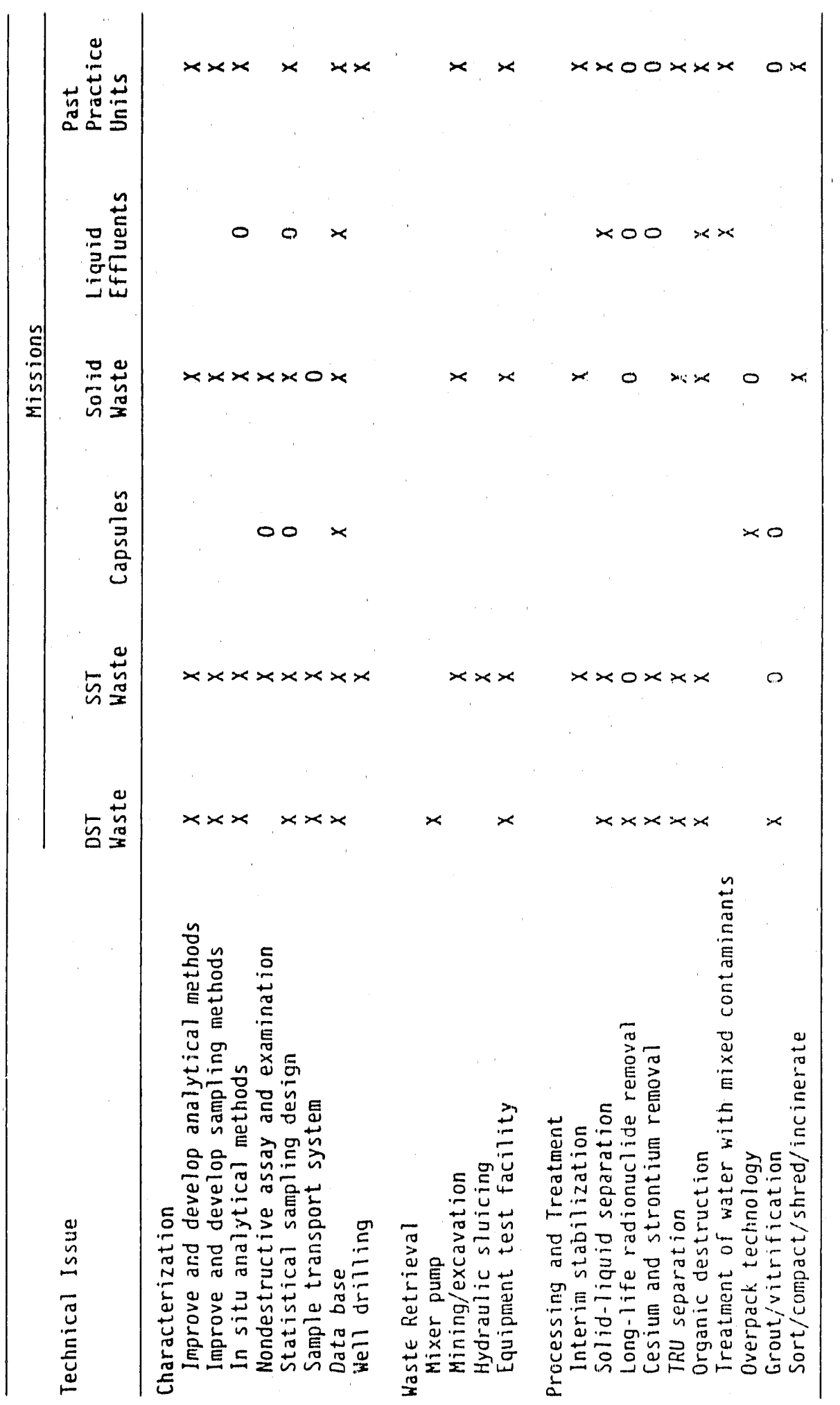


WHC-EP-0348

Table 3-1. Technology Issues Matrtx. (sheet 2. of 2)

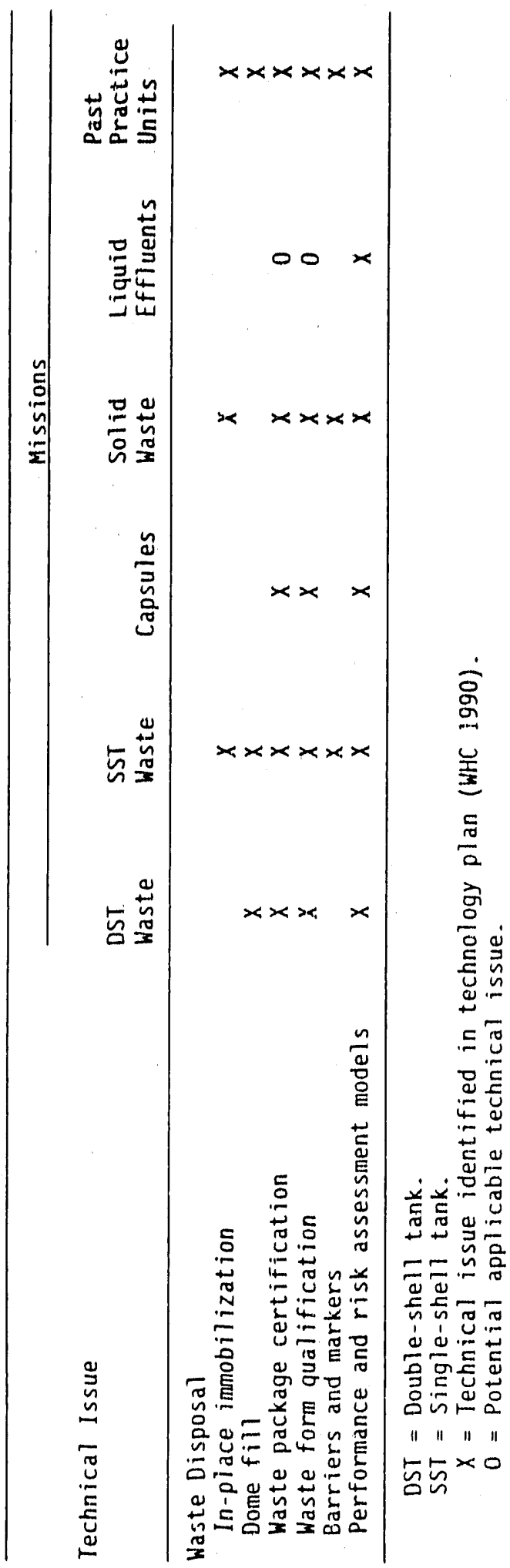


The EPA methods for chemical and radiochemical analyses are based on dllute solutions and, in many cases, need to be modiffed to meet required detection 11 mits for Hanford Site waste slurries. New and improved analytical methods are being developed by the DST and SST misstons for detecting spectfic elements in the complicated Hanford Site waste matrices. These spectfic elements inclyde: noblemetals, mercury, and radioisotopes such as $129 \mathrm{I}, 218 \mathrm{~Pb}, 231 \mathrm{~Pa},{ }^{9} \mathrm{Se}$, and $227 \mathrm{AC}$. The PPU misston ts developing analytical methods for measuring organic and inorgantc toxtcants in soll. Many of these methods will be applicable to the solid waste misston.

In situ analytical techniques have been identifted as a viable means for significantly reducing characterization costs and cleanup schedules. Examples of in situ technlques that are needed by several misstons include real-time radiological mapping (SST, solid waste, and PPU missions) and TRU detection and analysis to elfminate unnecessary retrleval and/or processing (DST, SST, solid waste, and PPU missions).

Noridestructive examination methods for waste containers and internal components are needed by the DST, SST, capsules, and soltd waste misstons to evaluate the safety of the retrieval technology. Nondestructive assay methods to classify drums of waste are needed by the solid waste and PPU missions. New nondestructive assay technology will potentially decrease worker exposure and also decrease processing costs by identifying drums that can be certified for disposal without processirig.

\subsubsection{Waste Retrieval}

Every effort must be made to retrieve wastes in a manner that prevents the spread of contamination and that minimizes the generation of secondary waste. Waste forms potentially requiring retrieval include slurries, containerized and uncontainerized solid waste, remote- and contact-handled TRU solid waste, contaminated soil, contaminated groundwater, and saltcake and sludges from SSTs. The acceptability of extsting retrieval techniques is questionable for most of the waste forms identified, including (1) drummed or boxed waste with breached or deteriorated containers, (2) contamiriated soil, (3) remote-handled TRU solid waste in caissons, and (4) saltcake and sludge from SSTs. Avallable technology identified to retrieve those wastes currently relies on industrial techniques that may be inadequate for the radioactive environments and diverse types of tasks that must be performed. Current technologies may need to be adapted to the Hanford environment, and in some cases new technology may need to be developed and made avallable in time to comply with schedules imposed by state and federal regulations and the Tri-Party Agreement.

Mixer pumps are being adopted for retrieving slurrtes from DSTs. These pumps are submerged in the waste and create two opposing, high-velocity jets of tank fluid. As the pump(s) rotate, the fluid jets resuspend the settled 
solids, allowing the transfer pump to retrleve the resultant slurry. Mixer pumps also may have application in the HWVP, where it is cructal to the waste form qualiftcation efforts to provide a untform mixture of feed to the HWVP feed preparation system. With further development, mixer pump technology may be applicable to the solid waste and PpU misstons in the area of subsidence control (grout injection technology).

Mining and excavation technology is needed by the solld waste misston for retrleving wastes in calssoris and trenches; by the SST mission for retrleving saltcake and sludge; and by the SST, solld waste, and PPU misstons for retrleving contamilnated soll. The applicable retrleval technology must provide for the containment of waste (e.g., minimize the spread of contamination by the wind or breaches in contalners) and decrease worker exposure. Hydraulis slutcing technology is being studted for retrieving waste from SSTs and potentially for retrieving contaminated solls.

\subsubsection{Processing and Treatment}

Processing and treatment (including pretreatment) technologies are being developed to meet regulatory requirements and to minimize the total cost of disposal by sorting or separating certain contaminants. Treatment technologies that do not adequately perform their function(s) could delay final disposal actions and result in waste forms that do not meet waste acceptance criterta. Significant cost savings can result if processing and treatment technologies are developed that significantly reduce the fraction of the waste requiting the higher cost treatment.

A methodology is needed for removing and segregating TRU elements from many dlfferent typas of waste, thereby reducing the volume of TRU waste sent to WIPP. The DST mission is evaluating a transurantc TRU extraction process, which might be adapted for SST waste, if needed. The solld waste and PPU missions may need to develop a methodology for removing and segregating TRU elements from soils.

The mobility of complexed radionuclides in the Hanford Stte soils and sediments is largely unknown. At this time, it is conservatively assumed that complexed spectes will be unacceptably moblle. Also, the presence of organics can significantly impact the effectiveness of the grout disposal action. Therefore, the organic spectes may need to be destroyed or significantly reduced in DST and SST waste as well as in contaminated soll and groundwater. The DST mission is investigating processes for treating retrieved waste while the SST mission is evaluating in-tank complexant destruction. Results from these studies may be useful to the PPU mission for cleaning up soll and groundwater contaminated with organics. 
WHC - EP-0348

\subsubsection{Waste Disposal}

The primary goal of waste disposal technology development is to provide the most acceptable final waste forms and emplacements to ensure public safoty and environmental protection. If post-disposal monttoring indicates that the final waste forms do not adequately control release to the environ. ment, the wastes may need to be exhumed and reprocessed, or additional barriers may need to be applied.

In place immobilization technology candidates being evaluated by the SST and PPU missions include grouting and in situ vitrification. Grout formulations and injection techntques are being investigated for SST waste and surrounding soll. This technology is al so noeded for ret ired liquid waste disposal crlbs and calssons, which are the responstbility of the PPU mission. Grout injection technology also may be applicable to subsidence control, a concern of the soltd waste and PPU mlsstons.

The in situ vitrification technology (a process that fuses contaminated solids into arl immoblle glass form) was concelved in 1980 by Pactfic Northwest Laboratory and has been tested extenstvely at the bench. and pllot-scale on contaminated sol'is at the Hanford Site and other DOE sites. Five largescale tests of the in situ vitrification process have also been performed. This technology is being further investigated for immobllizing soll with large burted objects (e.g., drums) and for tmmobllizing SSTs and surrounding soll.

Dome-f1ll technology is being tested for the SST waste disposal option where the tanks are left intact. The vold space in the tank must be filled to minimize the effects of subsidence, which could compromise the effectiveness of the surface protective barrier. This same technology may have appli. cation in remediating DST. Dome-fill technology also is being investigated by the PPU mission for subsidence control of cribs, caissons, and industrial waste packages.

Protective barrters are an essential component in the disposal of wastes burted or immoblitized near the earth's surface. Protective barrters are being developed by the SST mission for use in controlling the potentlal transport of radtonuclides and other contaminants caused by ralnwater intruston, winds, burrowing animals, and other natural phenomena, as well as for use in protecting the inadvertent intruder from radiation exposure. Current barrier and marker system designs use engineered layers of natural materials to create an integrated structure with redundant protective features. Barrier technology will also be used by the solid waste and PPU misstons.

\subsection{TREATMENT, STORAGE, AND DISPOSAL FACILITIES}

The existing or planned facilities for the treatment, storage and disposal of Hanford Site wastes are listed in Table 3-2. The function of each of these factlities and the planned or potential utilization of these facllities are also identified. 
Tabie 3-2. Treatment, Sturage, and Disposal Facllities. (sheet 1 of 2)

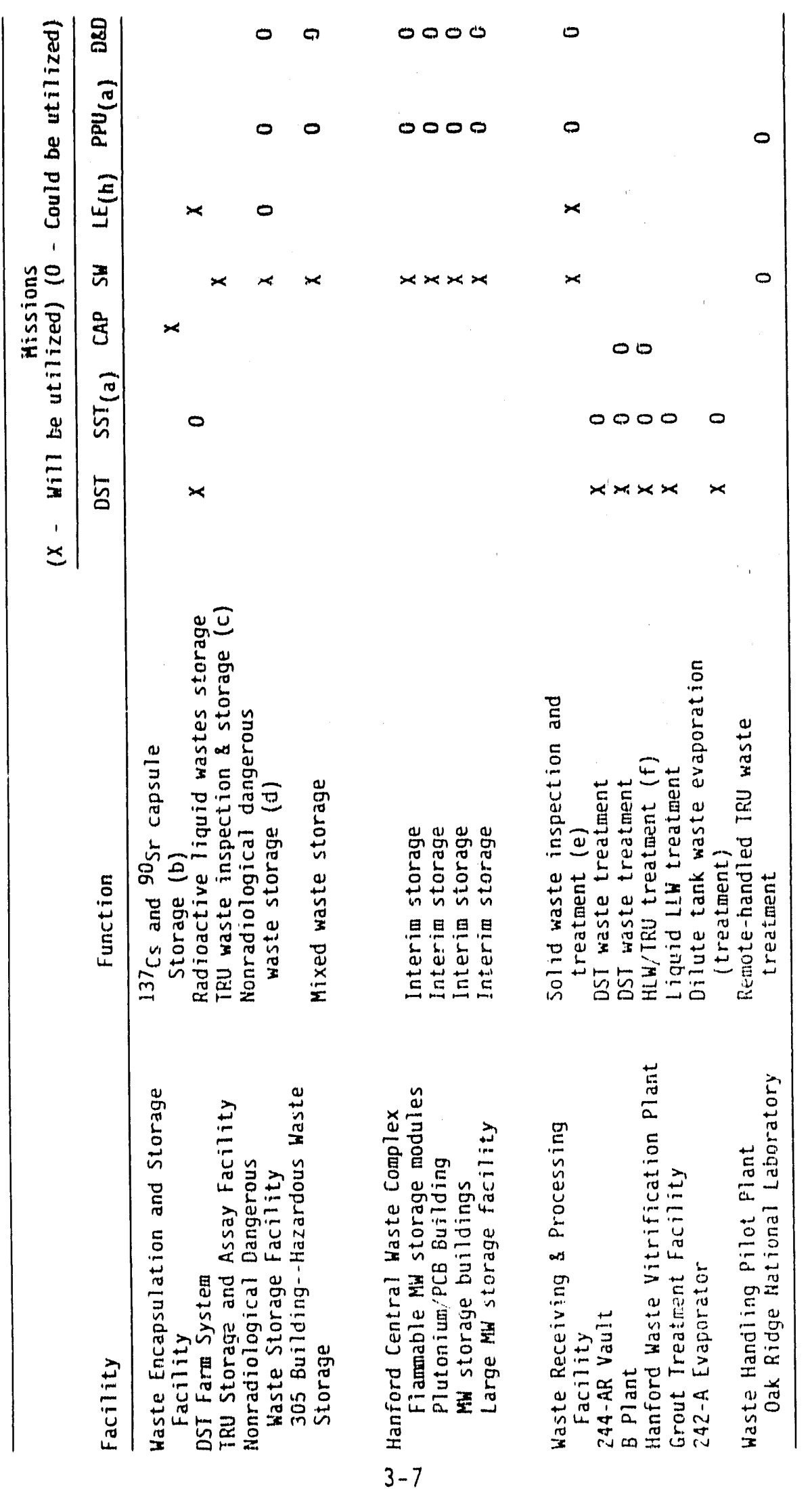


Table 3-2. Treatment, Storage, and D1sposal Factlittes, (sheet 1 of 2)

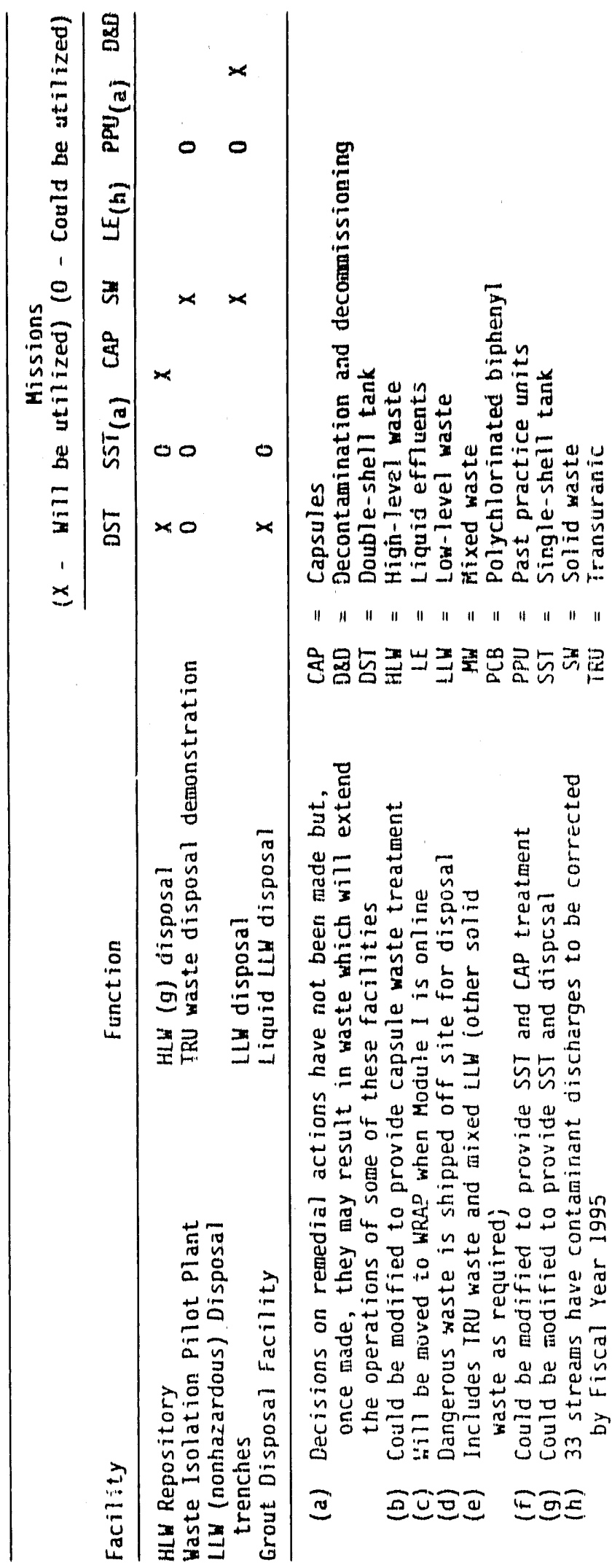


Table 3-2 11lustrates that existing or planned factlittes could be ut lized to implement decistons that are forthcoming. For example, the hot cells at the Waste Encapsulation and Storage Facllity could be modifted to accommodate any treatment that intght be necessary to convert the cestum chlortde and strontlum fluoride to an acceptable waste form. As another example, the HWVP operations could be extended to accommodate the treatment of encapsulated waste or SST waste.

Table 3-2 does not attempt to address the sultability of a facillty for extended operation. The B Plant, for example, has been determined to be sultable for pretreatment of DST wastes, scheduled to conclude by FY 2004 . If the pretreatment is extended beyond Fy 2004 as a result of forthcoming dectstons for other missions, the suttability of B Plant would need to be evaluated. 


\subsection{DOUBLE-SHELL TANK WASTES}

\subsection{INTERIM STORAGE AND SURVEILLANCE}

Twenty-eight DSTs are in service wjth a total capacity of $118,400 \mathrm{~m}^{3}$ as shown in Table 4-1. There are $78,000 \mathrm{~m}^{3}$ of UST waste that have accumulated as of December 31,1988 with a total radionuclide content of $111 \mathrm{MC} 1$ (DOE 1989). More wastes are expected, with the primary source coming from cont inued PUREX Plant operations.

Table 4-1. Double-Shel1 Tank Capacities.

\begin{tabular}{lccr}
\hline Tank farm & $\begin{array}{c}\text { Number } \\
\text { of tanks }\end{array}$ & Each tapactty & $\left(\mathrm{m}^{3}\right)$ \\
\hline $241-\mathrm{AN}$ & 7 & 4,300 & Total \\
$241-\mathrm{AP}$ & 8 & 4,300 & 30,100 \\
$241-\mathrm{AW}$ & 6 & 4,300 & 34,400 \\
$241-\mathrm{AY}$ & 2 & 3,800 & 25,800 \\
$241-\mathrm{AZ}$ & 2 & 3,800 & 7,600 \\
$241-\mathrm{SY}$ & $\frac{3}{28}$ & 4,300 & 7,600 \\
Total & & & 12,900 \\
\hline
\end{tabular}

The neutralized current acid waste from the PUREX Plant is being accumulated and stored in the 241-AZ Tank Farm. The PFP waste is being stored in one of three waste tanks in the 241"SY Tank Farm. Both the complexant concentrate, resulting mostly from the former fractionization processes at $B$ Plant, and neutralized cladding removal waste from the PUREX Plant are being stored in 6 select tanks within the tank farms. The remaining DSTs etther store LLW, are used for staging matertal transfers, or are designated as spares.

Several million liters of dilute LLW are received annually from operating facilities throughout the Hanford Site. The streams from the 200 Areas are transferred by underground piping and collected in the DST system. The streams from the 100 and 300 Areas are delivered by railcar to the 204-AR unloading facility and transferred to the DST system. These dilute LLW streams are ieceived and concentrated in the 242-A Evaporator-Crystallizer. The concentrated bottoms product from evaporation of DST supernatants and SST interstitial liquors, pumped from SSTs as part of interim stabilization, are referred to as double-shell slurry. A diluted form of double-shell slurry is referred to as double-shell slurry feed but will not be addressed separately here. 
Interim operations concerns the storage and surveillance of neutralized current acid waste, PFP waste, complexant concentrate, neutralized cladding removal waste, and evaporating the supernatant from these streams to store a concentrated slurry in the minimum amount of space possible. Following interim storage and surveillance, the concern is for treatment required to convert the waste to a form that is acceptable for disposal.

\subsection{TREATMENT AND DISPOSAL}

A flowchart for the treatment and disposal of DST wastes is shown in Figure 4-1. The neutralized current acid waste and complexant concenirate have been identified as sources of HLW fractions. The PFP waste and neutralized cladding removal waste have been identified as sources of TRU waste. Each of these streams will be pretreated at the 244-AR Vault and/or $B$ Plant. The potential processes for treating these streams include solidliquid secration and sludge washing, ion exchange (such as cesium removal), TRU extraction selective leaching, and organic destruction.

The 244-AR Vault and $B$ Plant processing will result in a high-level fraction of relatively low vclume for feed to the HWVP and a low-level fraction of relatively large volume for feed to the Grout Treatment Facility. At the HWVP, the high-level fraction will be treated further by combining it with glass-forming materials, thereby immobilizing the waste in a glass matrix and packaging the glass in special canistered co:tainers for disposal in an HLW repository. The low-level fraction, including hazardous constituents, will be furiher treated in the Grout Treatment Facility by mixing with Portiand cement, fly ash, blast furnace slag, and a selected diluent. The grout mixture will be disposed of in near-surface grout vaults.

A demonstration campaign in the Grout Treatment Facility was initiated in August 1988 and completed in July 1989. In this campaign, a nonhazardous LLW, phosphate-sulfate waste from the decontamination of $\mathrm{N}$ Reactor process systems, was grouted and disposed of in a near-surface grout vault. Following the construction of new vaults and preparations for the next campaign in FY 1991, waste solutions containing hazardous components will be grouted after receiving a RCRA operating permit from the Washington State Department of Ecology. Thereafter, the low-level fractions from 244-AR Vault and B Plant pretreatment will be grouted.

Construction of the HWVP, a $\$ 965$ million line-item project, will be initiated in JuTy 1991. The construction is scheduled for completion in July 1998 and will be followed by cold runs. Hot startup is scheduled for December 1999.

As currently projected, the disposable wastes will include 1,460 vitrified glasss canisters $\left(0.62 \mathrm{~m}^{3}\right.$ each) of $\mathrm{HLW}_{3} 500$ vitrified glass canisters (a) so $0.62 \mathrm{~m}^{3}$ each) of JRU waste, and $233,000 \mathrm{~m}^{3}$ of grouted LLW (44 vauits

each containing $5,300 \mathrm{~m}^{3}$ ). 
Figure 4-1. Treatment and Disposal of Double-Shell Tank Wastes.

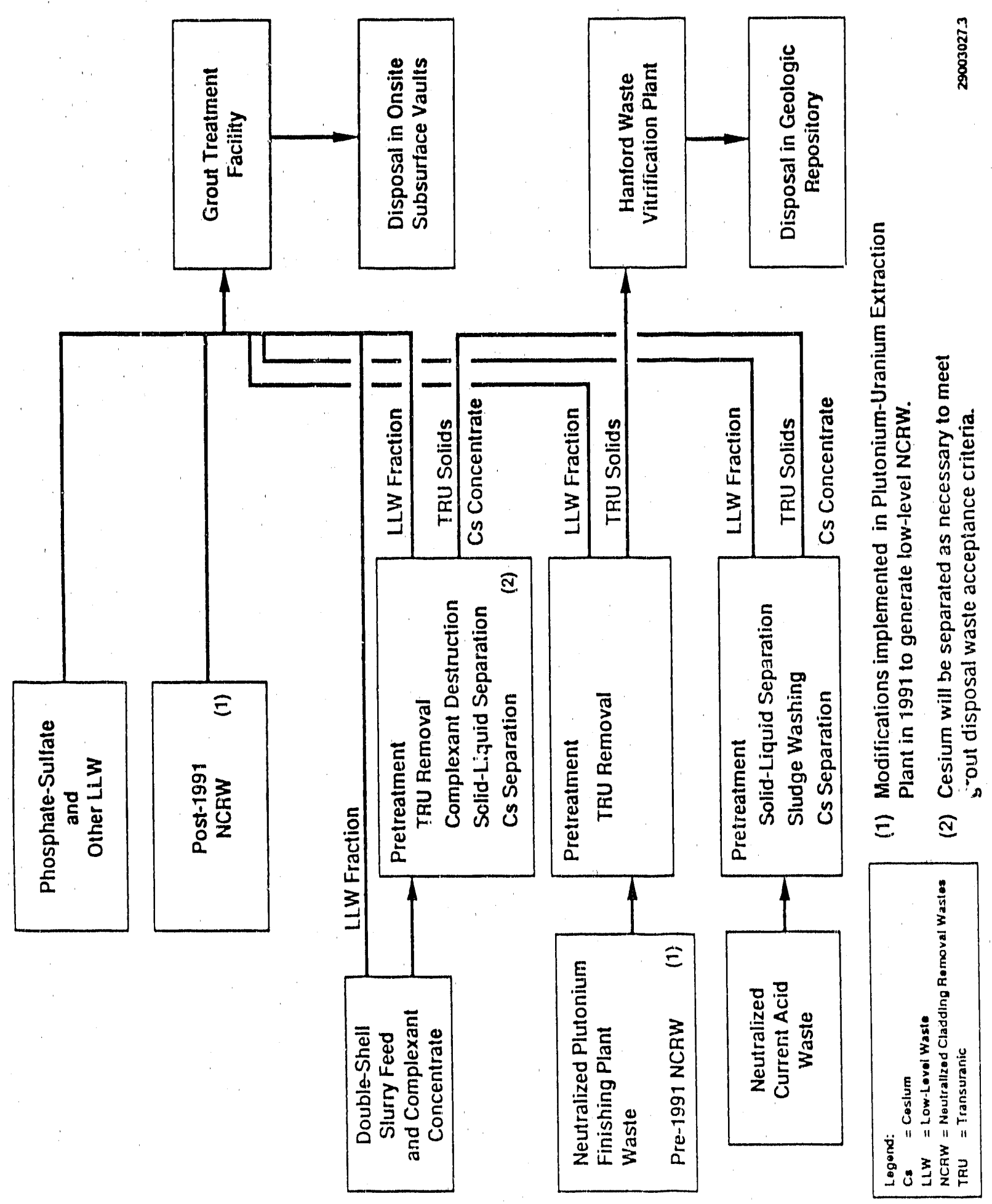




\subsection{ACTIVITY NETWORK}

The Level 1 activity network for the DST mission is presented in Figure 4-2. This activity network displays, in a logical order, the activitjes that must be performed to complete the DST mission. The network is set as follows.

- Activities associated with grout disposal are presented along the top of the network.

- Activities associated with waste retrieval and pretreatment are presented in the middle of the network.

- Activities associated with vitrification are presented along the bottom of the network.

The activities have been presented in this manner for easy identification of the activities that feed more than one of these three W.C. and thus may require more attention to ensure the interfaces are properiy managed. 


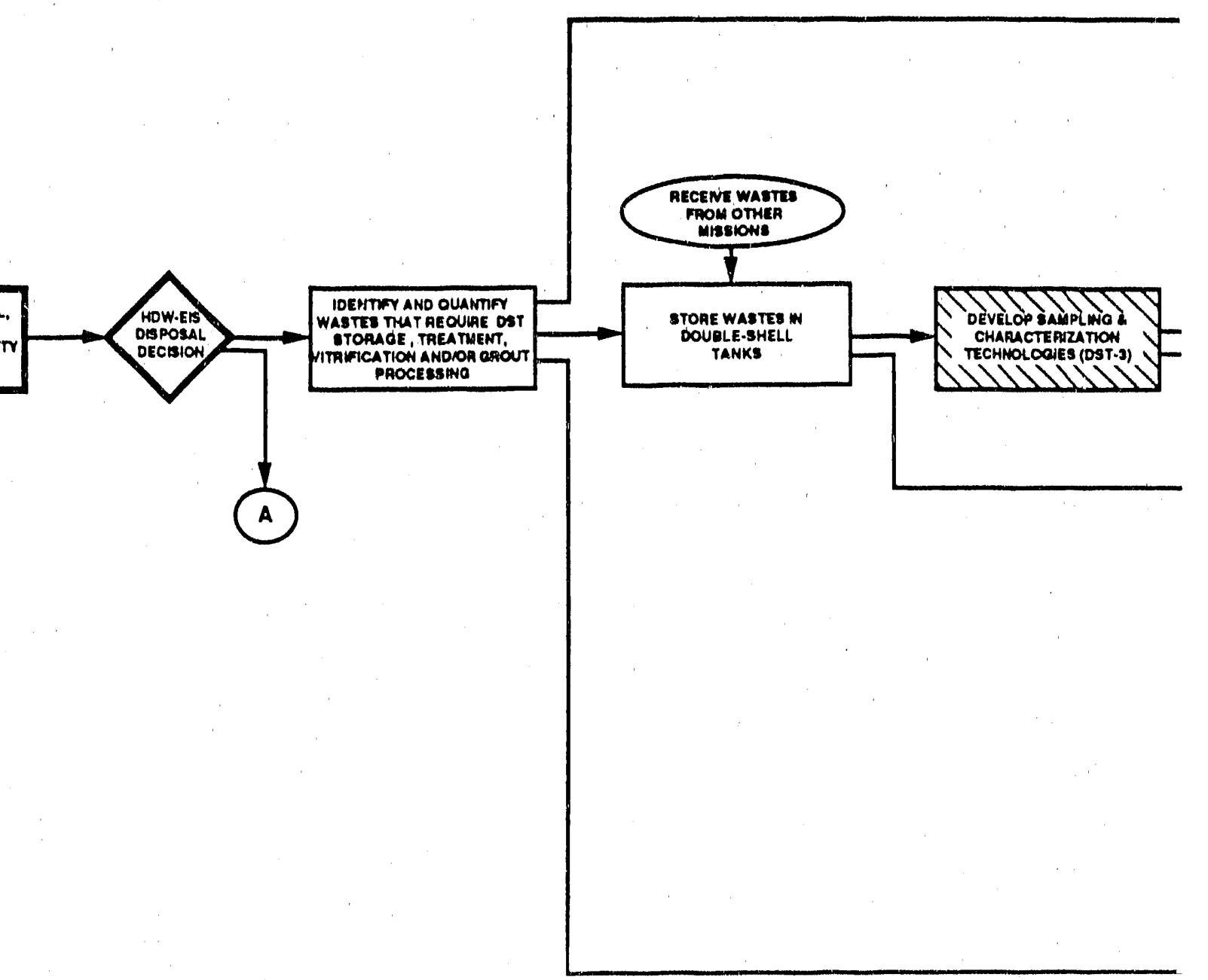

:

I

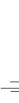

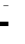

I 


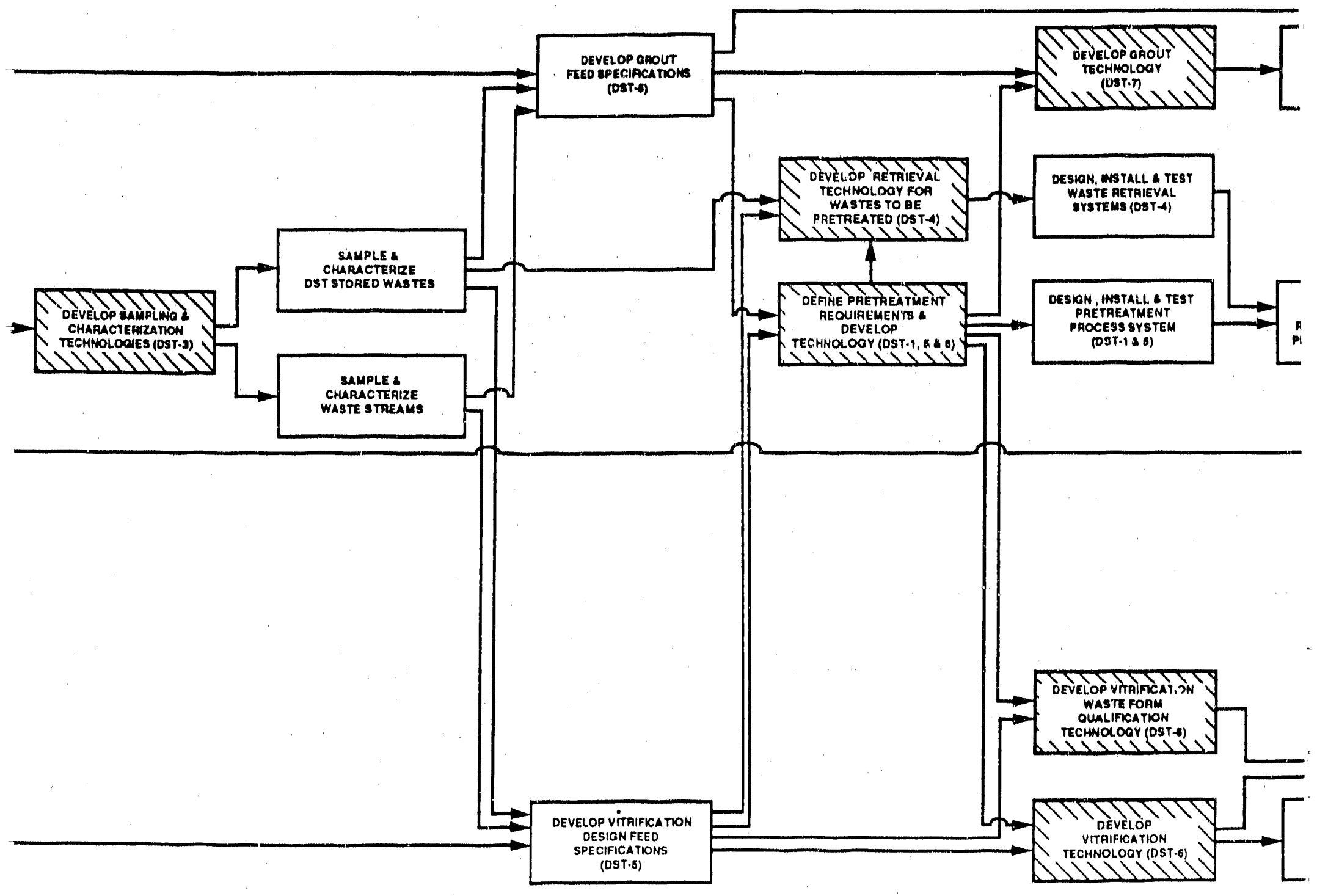




\section{WASTE MANAGEMENT \\ DOUBLE-SHELL TANK MISSION \\ LEVEL 1 ACTIVITY NETWORK}

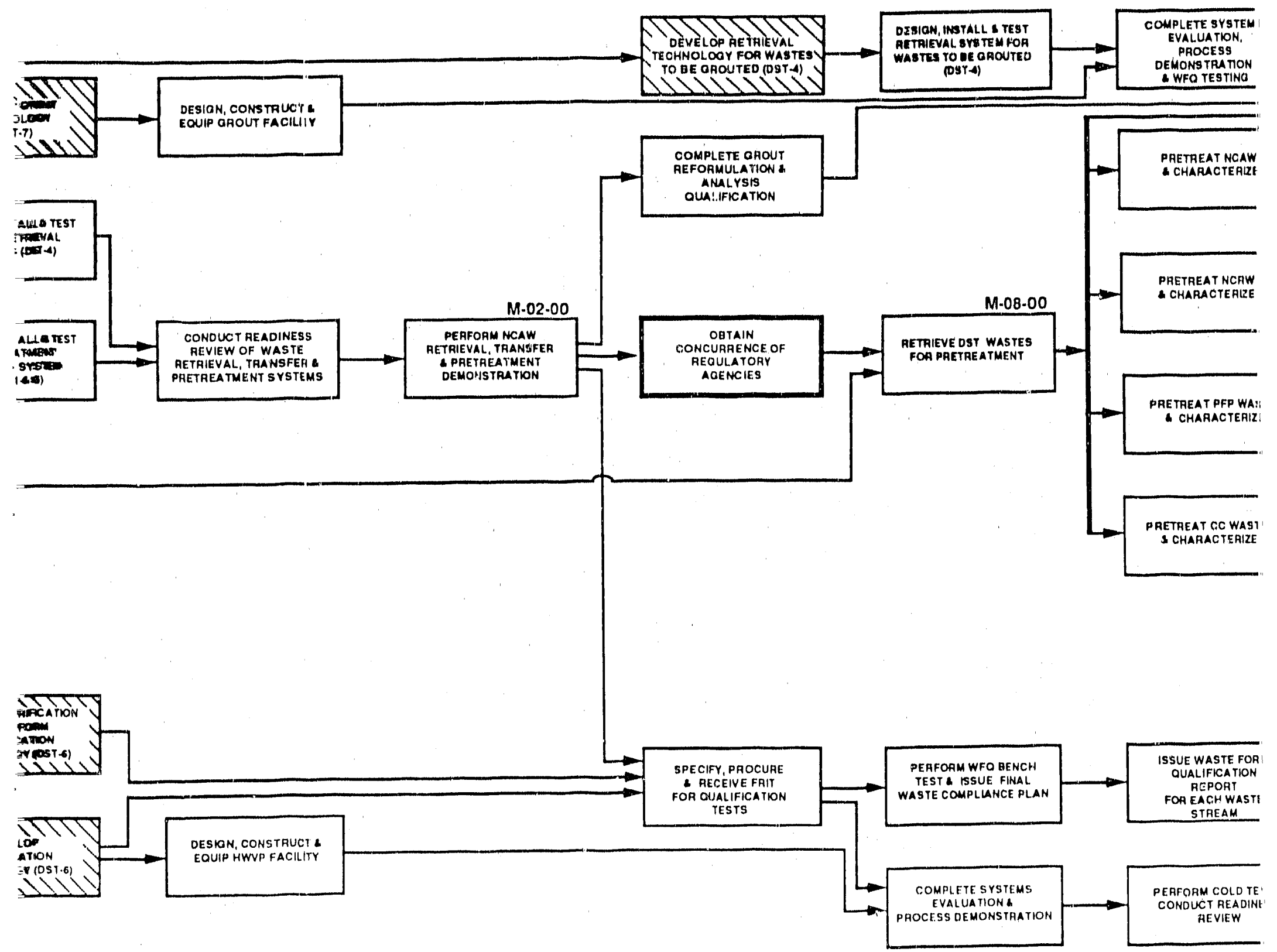

M.01.00 COMPLETE 14 GROUT CAMPALNS OF DOUQLE - SHELL TANK WASTE M-02.00 INITL TE B.PLANT OPERATIONS FOA PRETREATMENT OF DOUBLE . SHELL TANK WASTE 10.03 M.0300 INITLATE HANFORD WASTE VITRIFICAYION PLANT OPERATKONS

M.00.00 INITLTE FULL.SCALE TANK FARM CLOSUAE DEMONSTRATION PACUECT 


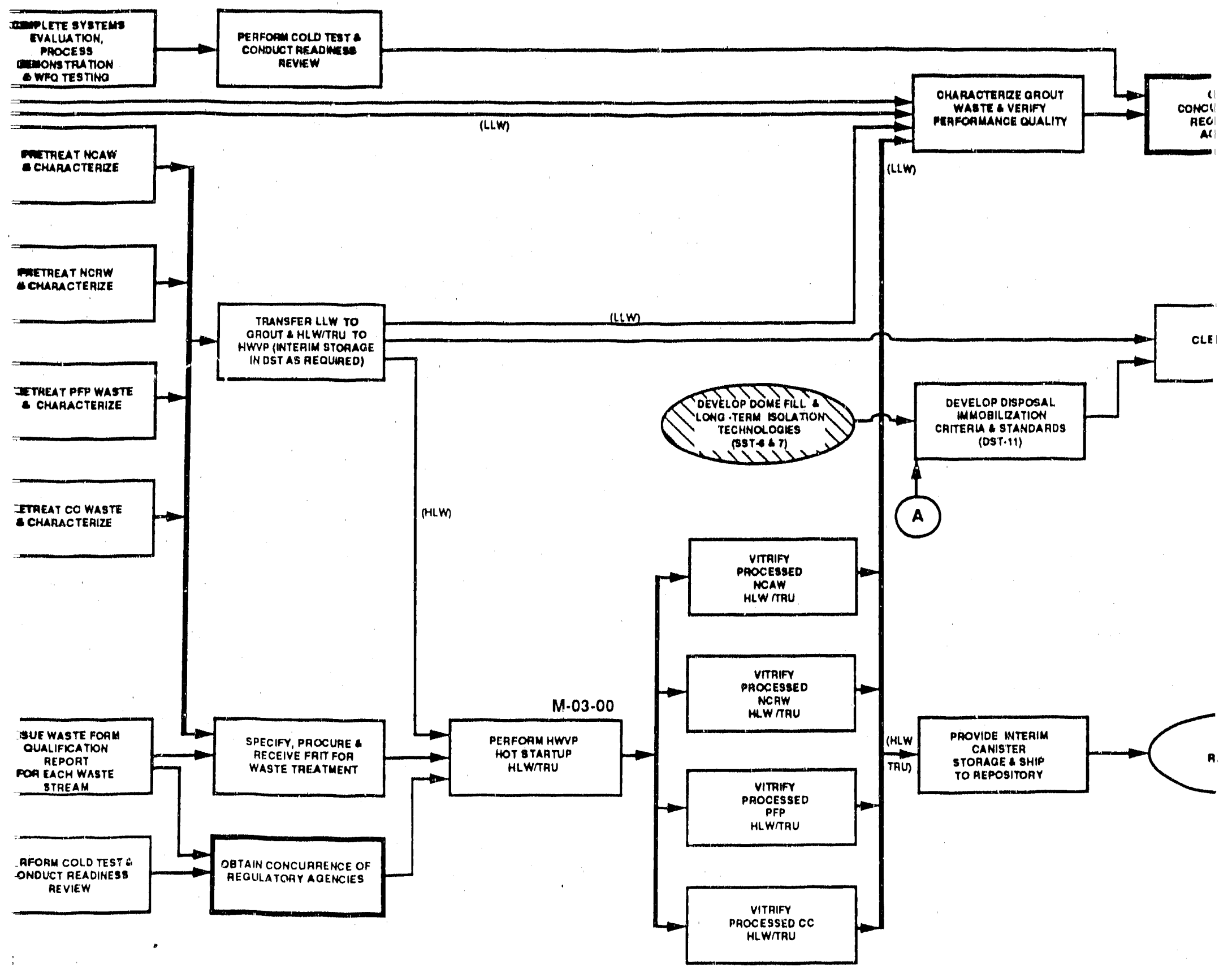

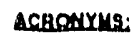

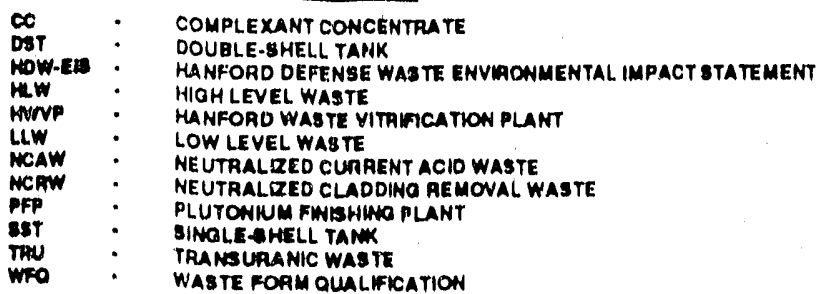



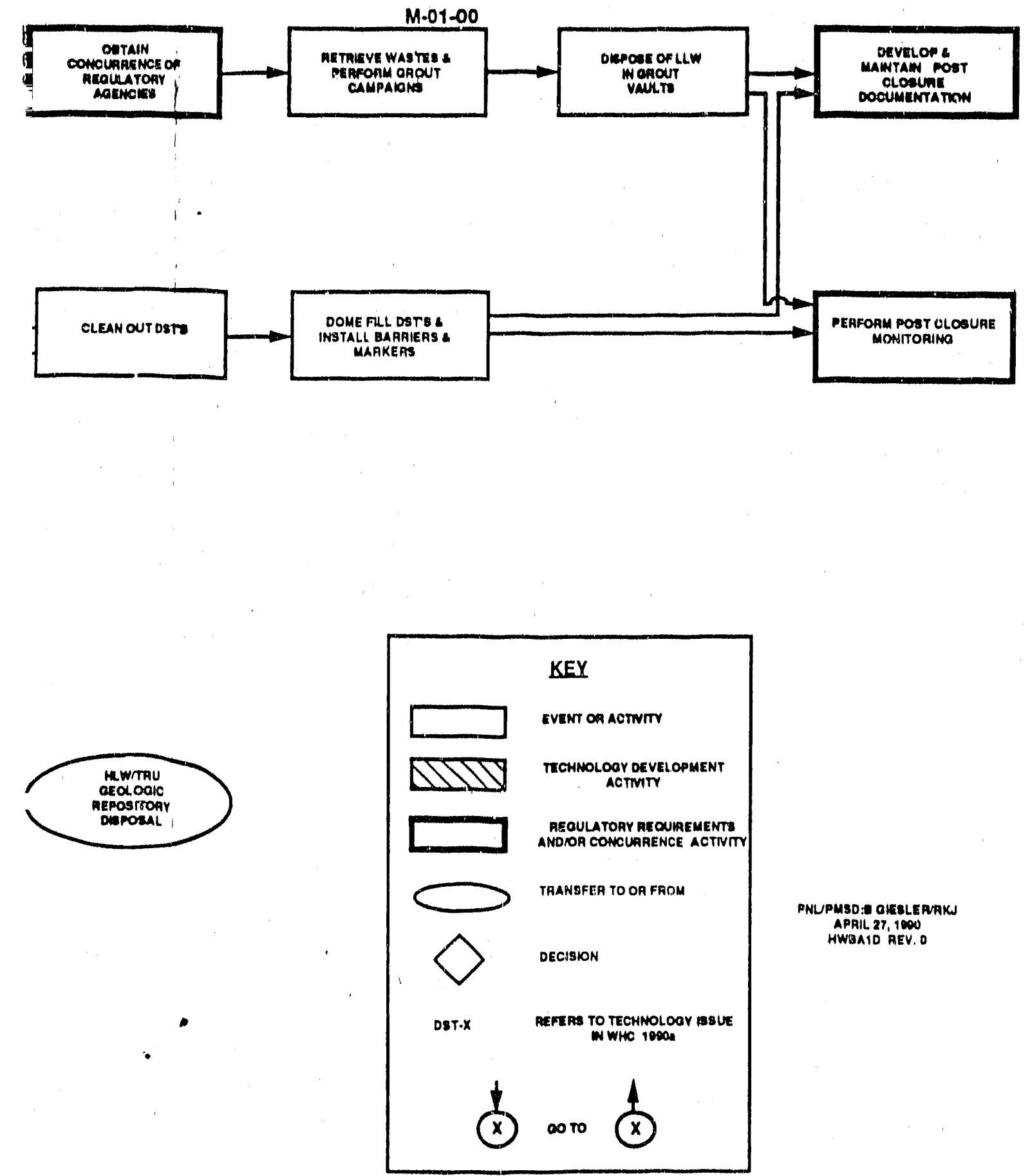

Figur 42. Activity Network For Doublo-shwil Tank 
WHC-EP-0348

\subsection{SINGLE-SHELL TANK WASTES}

\subsection{INTERIM STORAGE AND SURVEILLANCE}

The Waste Management Program is funding interfm storage and survelllance and the interim stabilization and isolation of the SST waste. Interim stab11 ization includes the removal of dratnable interstitial 1 lquor by September 1995. The Environmental Restoration Program is funding waste characterization and assessment in support of remedial actions.

There are approximately $139,000 \mathrm{~m}^{3}$ of waste containing $134 \mathrm{MC}$ of radtonuclides as of December 31, 1988 (DOE 1989), consisting of damp saltcake and sludge contained in 149 underground storage tanks. Within the interstices of the saltcake and sludge, there are $26,800 \mathrm{~m}^{3}$ of interstitial 1 lquor(s), containing $23 \mathrm{MCl}$ of radionuclides as of December 31,1988 . The portion of interstitial liquor(s) that drain into saltwells (e.e., well screens immersed in the solids) is being pumped to DSTs.

The waste accumulated from 1944 (at the inttiation of Hanford Site operations) unt 11 1980, when new waste transfers to the tanks ceased. Former processing included removal of water by pumping supernatant from the tanks for evaporation and returning the concentrated salt solution back to the tanks. The early fuel reprocessing activities did not remove uranium, which was sent to the tanks. During the late $1950^{\prime} \mathrm{s}$, a major program was undertaken to recover the uranium. Programs Implemented in the late 1960's removed the bulk of the radiocesium and radiostrontium for encapsulation.

Surveillance is required to ensure that the containment system functions within safety limits. To serve this purpose monitoring and leak detection systems are incorporated in the engineered system. Where a liquid surface exists, liquid level monitoring is used as the primary means of leak detection. Where the tanks do not have a liquid surface, liquid observation wells have been installed to monitor interstitial liquor. A series of dry wells located external to the tanks are routinely monitored to detect leakages. sixty-six tanks have been identified as either confirmed leakers or suspected leakers. Tanks in which unfavorably high temperatures could occur are equipped with thermocouples that provide temperature measurements.

Area radiation monitors located with in the tank farms indicate any gross loss of confinement, which would represent an immediate radiation hazard to personnel. Forced ventilation currently provides cooling for 11 tanks containing materials that, through radioactive decay, generate heat that could exceed established concrete temperature limits. Single-stage, highefficiency particulate air (HEPA) filters allow atmospheric breathing for tanks that do not require coolini. Gases generated by radiolytic decomposition disperse in this manner. All engineered systems undergo preventive maintenance, inspection, and cilizration. 
Future plans include completion of interim stabllization and fsolation of all 149 SSTs by September 1996, including those tanks that produce large amounts of heat.

\subsection{CHARACTERIZATION, DEVELOPMENT, AND DEMONSTRATION}

Six ou out of the total of 78 include both Resource Conservation and Recovery Act $3004(u)$, (1976) PPUs and the 149 SST treatment, storage, and disposal untts. During the pertod tin which intertm stabllization and isola. tion are being completed, the Environmental Restoration Program will support development of opt tmal waste retrieval and in-place disposal technologies for SST wastes. Promising retrieval technologtes will then be evaluated for each waste type, and one or more wtll be selected for testing using simulated waste in a scale-model (minimum 1:12 scale) tank.

Based on the scale-model testing, SST waste removal crtterta will be developed with EPA and Washington State Department of Ecology (Ecology) concurrence. The criteria will be used to complete the design of waste removal equipment in support of a future full-scale tank farm closure demonstration. Other Envtronmental Restoration Program actions in support of the Tri-party Agreement (Ecology et al. 1989) include the recovery and analysis of a minimum of two core samples from each SST. The sampling effort supports waste characterization, development of tank waste retrieval and in-place disposal technology, preparation of SST closure plans, and preparation of the environmental impact statement supplementing the Hanford Defense Waste Environmental Impact Statement (HDW-EIS) (DOE 1987a).

The SSTs have been determined by the EPA (Region 10) and Ecology to be RCRA storage units requiring a system closure and corrective action work plan. These tanks stopped receiving waste in 1980 and are part of the interim stabilization and isolation program. In accordance with the HDW-E.IS record of deciston (ROD) released in April 1988, additional development and evaluation w111 be conducted before making a disposal decision on SST waste.

Before the RCRA Facility Investigations processes are completed on the OUs containing the SST untts, key actions on SSTs will be required. These actions include waste characterization, barrier development, waste retrieval, waste processing, and criteria and standards development for proposed disposal systems. The SST waste characterization will be conducted in a manner approved by the regulatory aqencies and will include assessing the application of hazardous waste (HW) charactertzation protocols to characterizing mixed wastes. If variances to these protocols are required, such as defining sample sizes that do not compromise worker radiation limits, they will need to be approved by the regulatory agencies prior to initiating a full-scale char. acterization program. Criteria and standards based on applicable regulations or guidance will be developed to provide measures of performance. 
The crlterta and standards will eventually provide the basis for making final disposal recommendations for the SST waste. Support and consultation on SST characterlzation and other tasks is being provided by the National Academy of Sctences panel on SST Disposal Technology. As a result of the required prerequisities for SST OUs, the RCRA Faclltty Investigations/ Corrective Measure Study (RFI/CMS) process will start in FY 1992 and cont inue for a perlod of approxtmately ien years.

\subsection{ACTIVITY NETWORK}

The Level I activity network, describing the corrective actions required for the closure of SST waste and ancillary factllttes, is shown in Figure 5-1. 

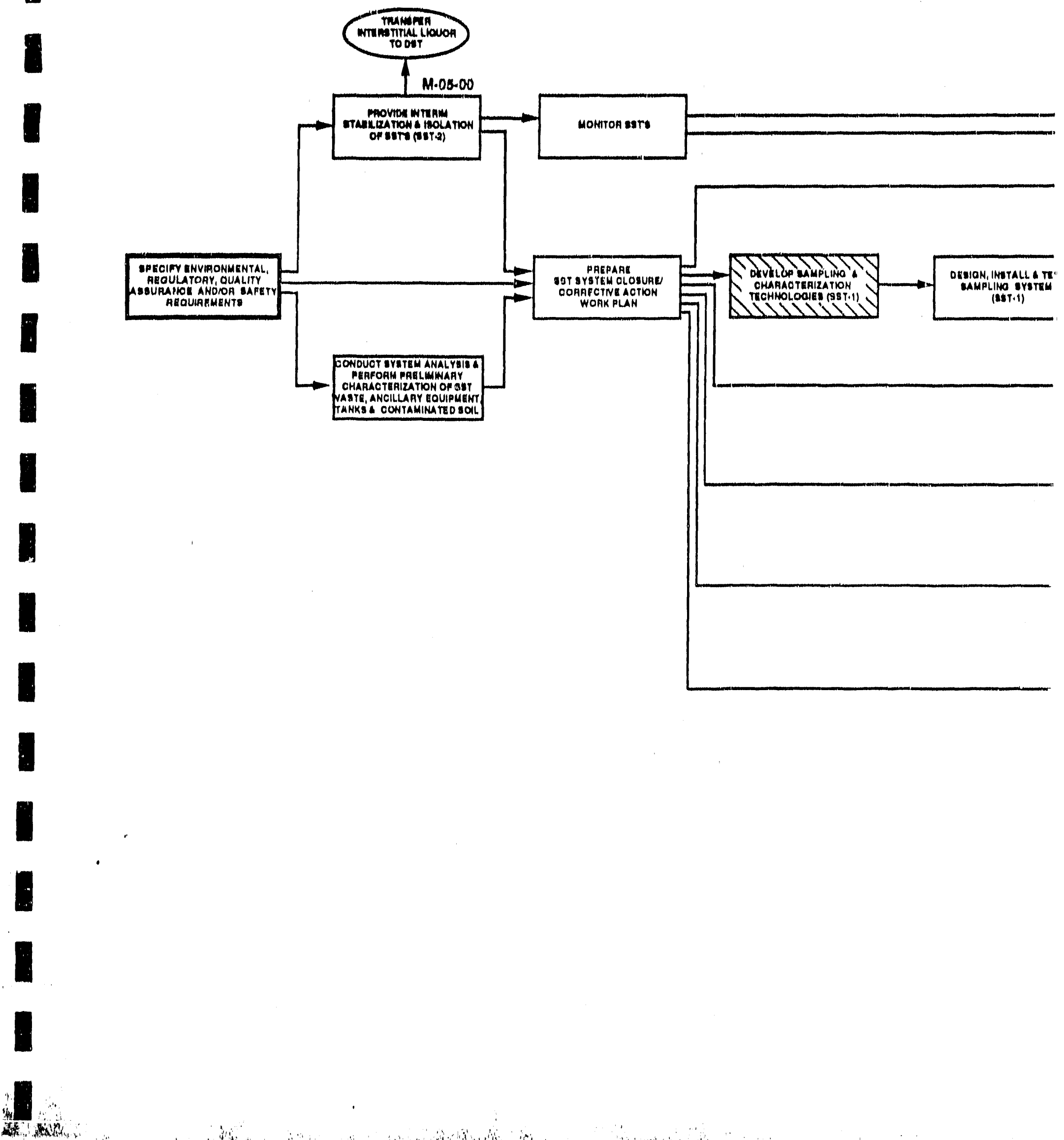


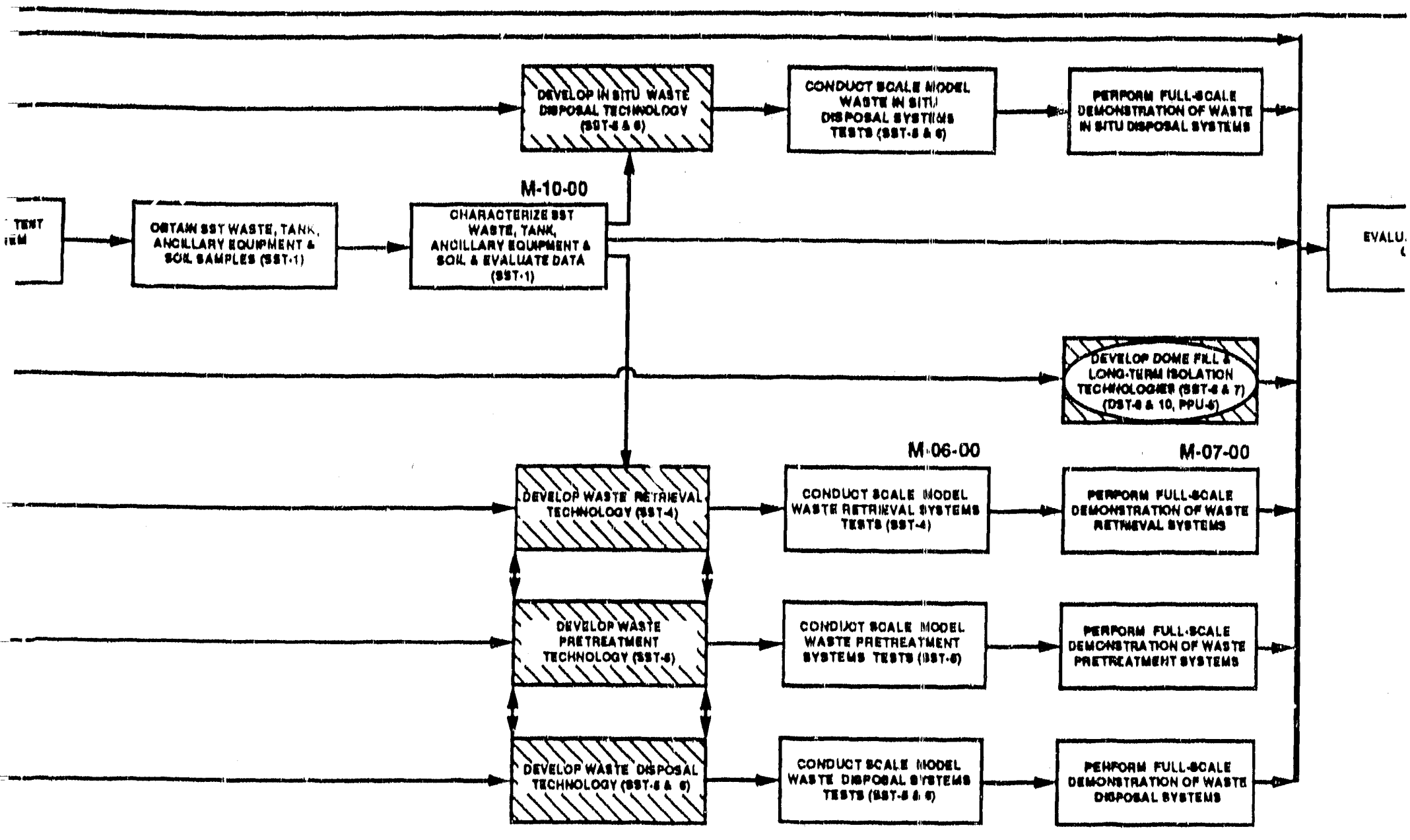




\section{ESTORATION \\ IK MISSION \\ NETWORK}

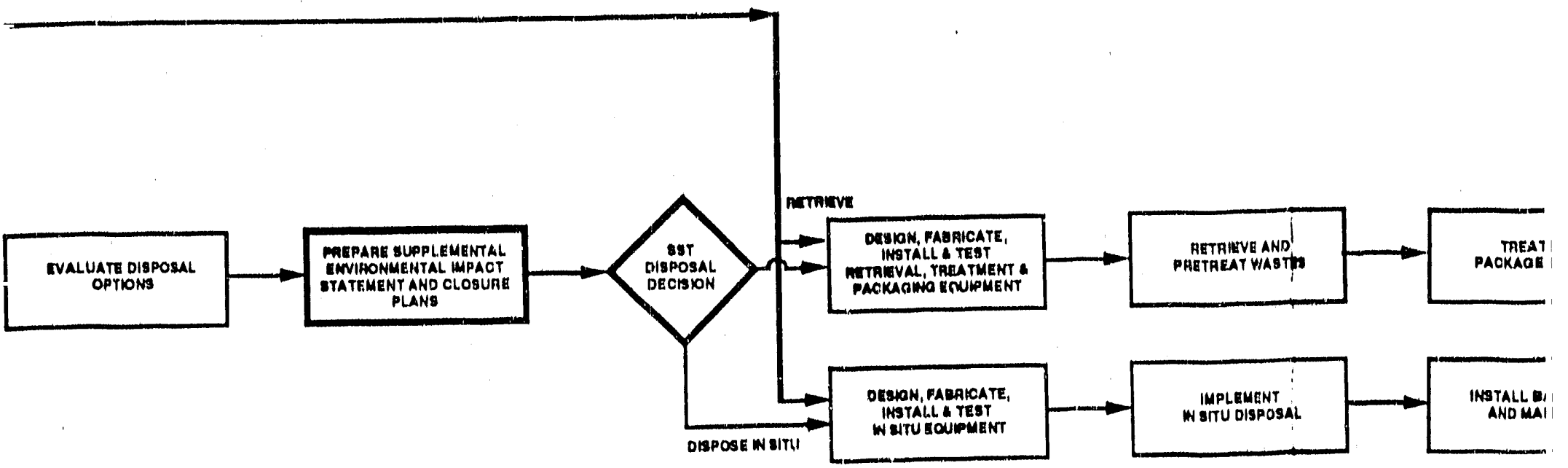

IRA MILESTONES

ที:

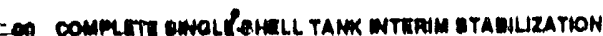

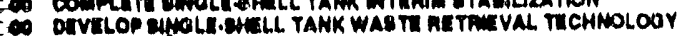
ano o r.

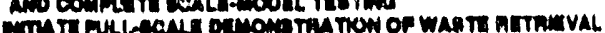

retwotoor

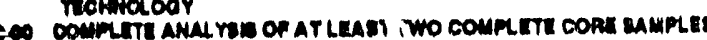

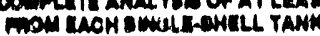

Dare:

008

ted

$10-\pi$

an
Masparum

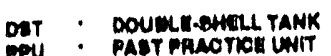

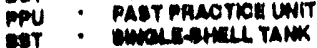

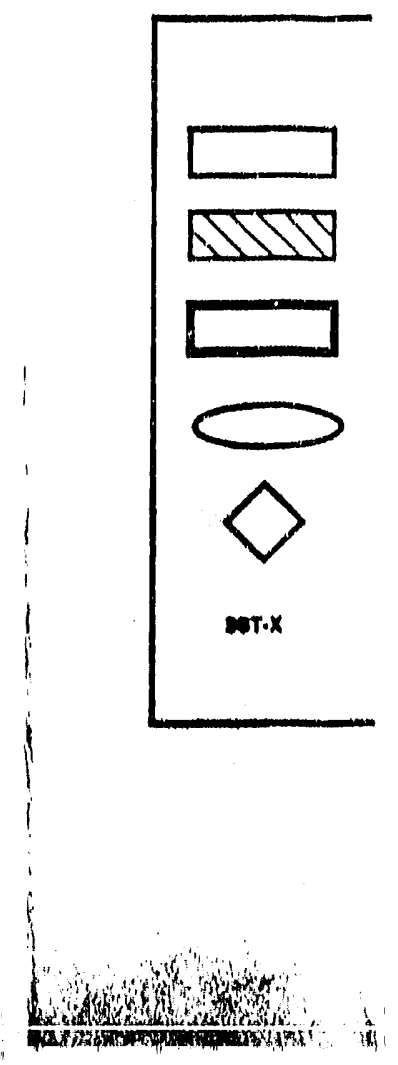



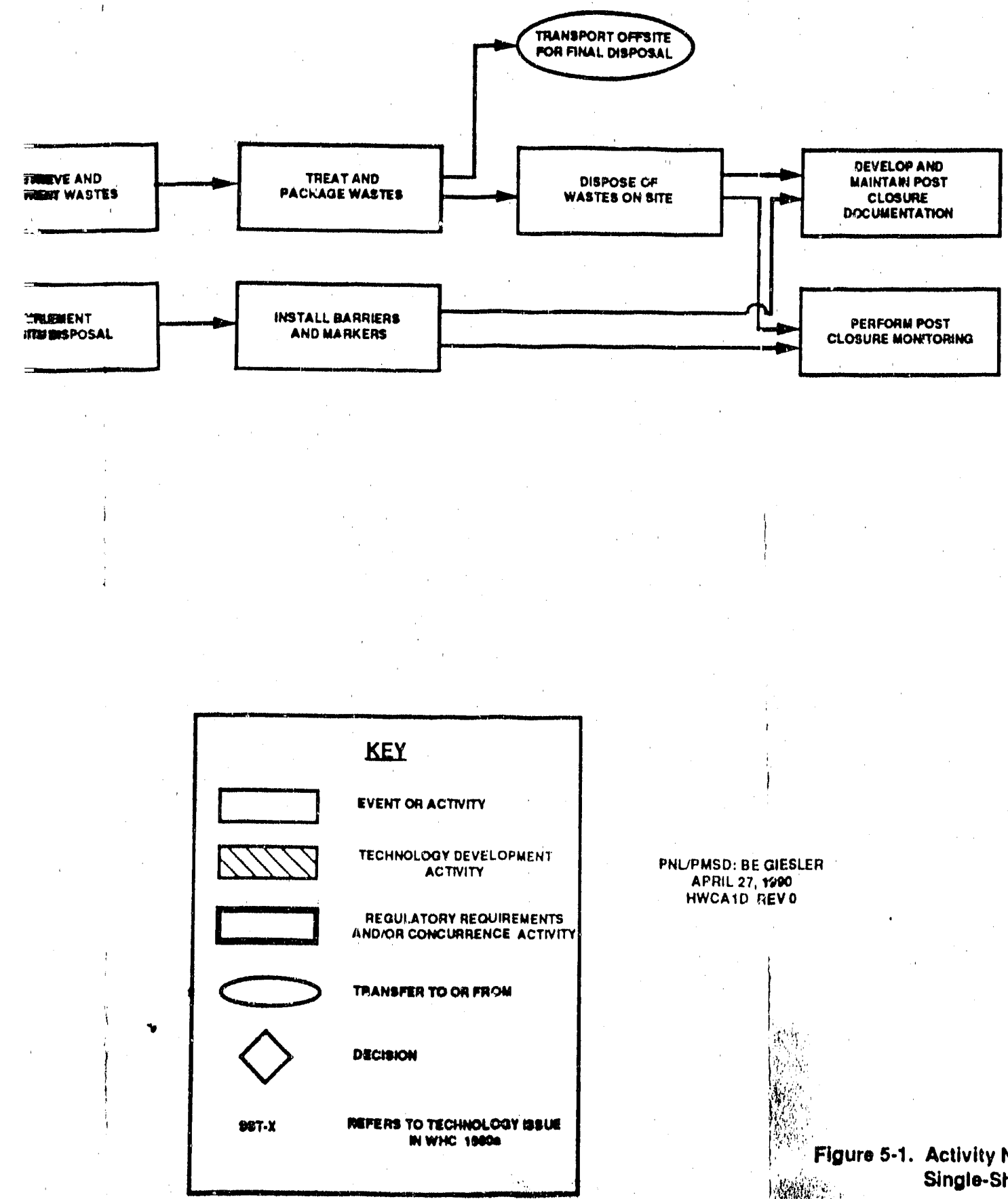

PNLPMSD: BE GIESLER

APRIL 27, 1000 HWCA1O REVO

Figure 5-1. Activity Network For 1) Singlo-Sholl Tank

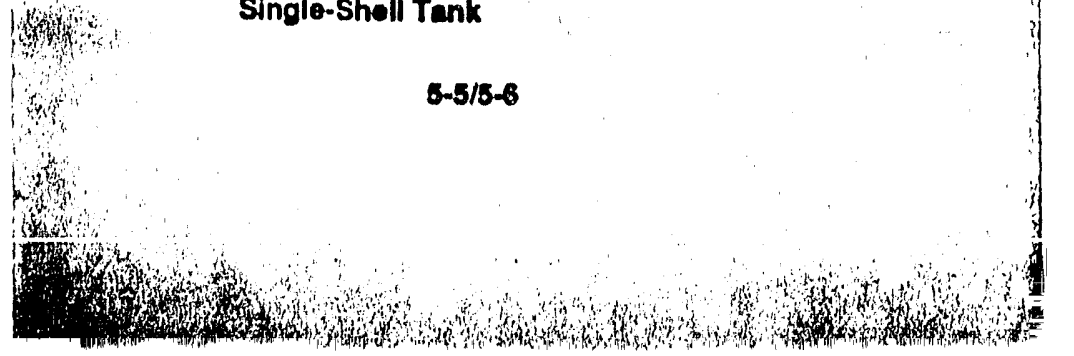


WHC - EP- 0348

\subsection{ENCAPSULATED RADIOCESIUM AND RADIOSTRONTIUM}

\subsection{INTERIM STORAGE AND SURVEILLANCE}

The encapsulation of radiocesium and radiostrontium, recovered from underground storage tanks, was completed in 1985. There were 1,576 cesium capsules produced in the form of cesium chloride encapsulated in double-walled stainless steel. There were 640 strontium capsules produced in the form of strontium fluoride encapsulated in hastelloy*. Currently, there are 1,349 cesium capsules with an activity of $121 \mathrm{MCi}$, and 597 strontium capsules with an activity of $56 \mathrm{MC} i$ (DOE 1989). The activity includes the contribution from the daughter isotopes. The remaining capsules, 227 containing cesium and 43 containing strontium, have been dismantled for beneficial uses and will not be returned to the Hanford Site. More capsules may be dismantled in the futcre.

The capsules that remain intact are either leased as irradiation sources (cesium-137) and radioisotope thermoelectric generators (strontium-90) or stored in water pools at the Waste Encapsulation and Storage Facility. Because of leakage of cesium into a leaseholder's storage pool in June of 1988, the cesium capsules are being returned to Waste Encapsulation and Storage Facility.

Storage of capsules in Waste Encapsulation and Storage Facility is a continuing activity that requires cooling water, makeup water, ventilation, and facility maintenance. Surveillance and monitoring of the pool water is maintained in the event of capsule leakage. There are no plans to produce more capsules.

\subsection{TREATMENT AND DISPOSAL}

Plans for disposal are to be developed by undertaking evaluations to determine the most cost-effective treatment to meet HLW repository waste acceptance criteria. The treatment will convert the existing forms, cesium chloride and strontium fluoride, to an acceptable form.

Until an evaluation yields a definitive treatment, the plans for the chosen disposal actions are uncertain.

\subsection{ACTIVITY NETWORK}

The Level 1 activity network for the disposal of encapsulated radiocesium and radiostrontium waste is shown in Figure 6-1. The HDW-EIS decision to overpack the capsules for repository disposal forms the starting point for the activities shown.

* Hastelloy is a trademark of Cabot Corporation, Kokomo, Indiana.

$$
6-1 / 6-2
$$



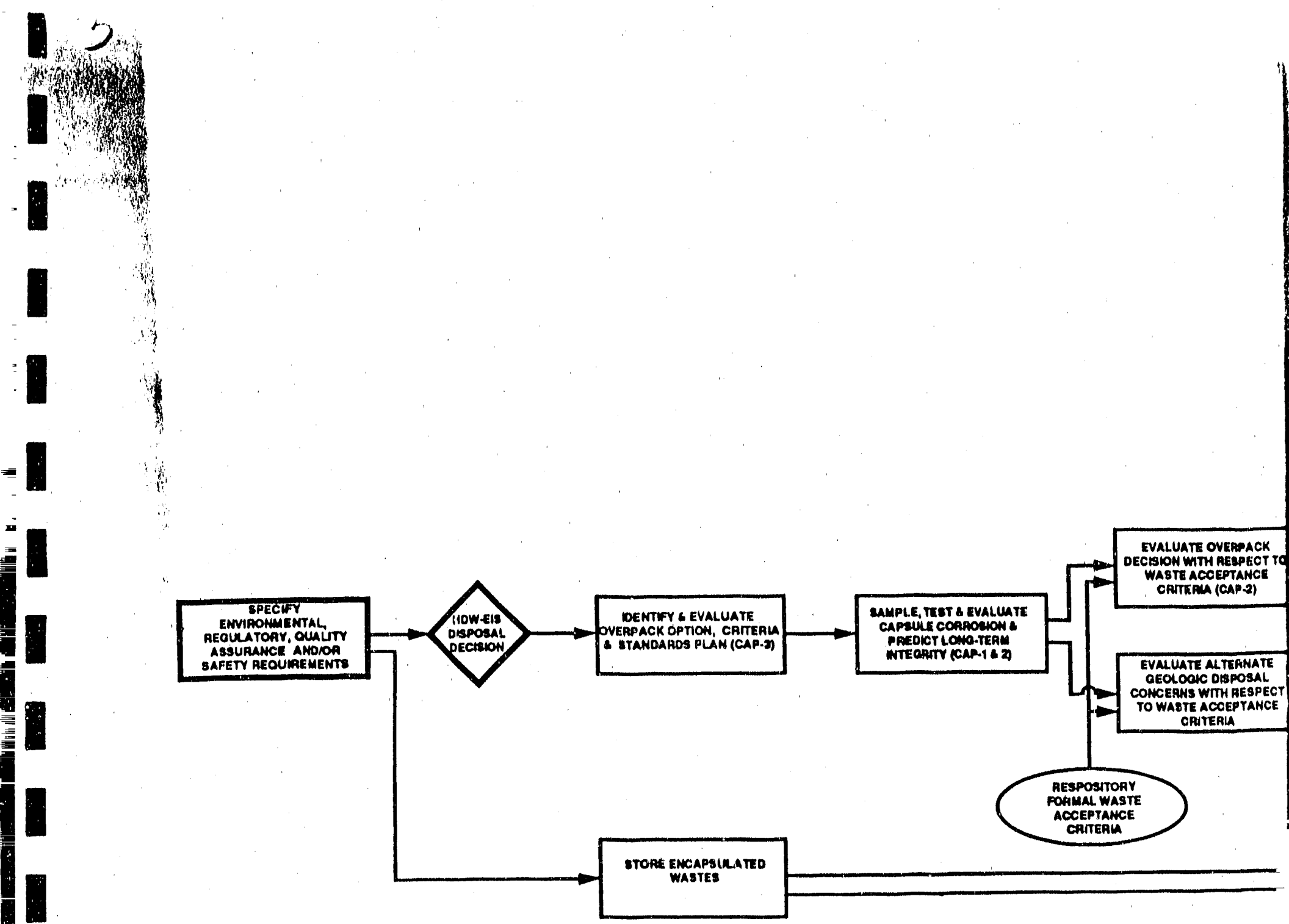


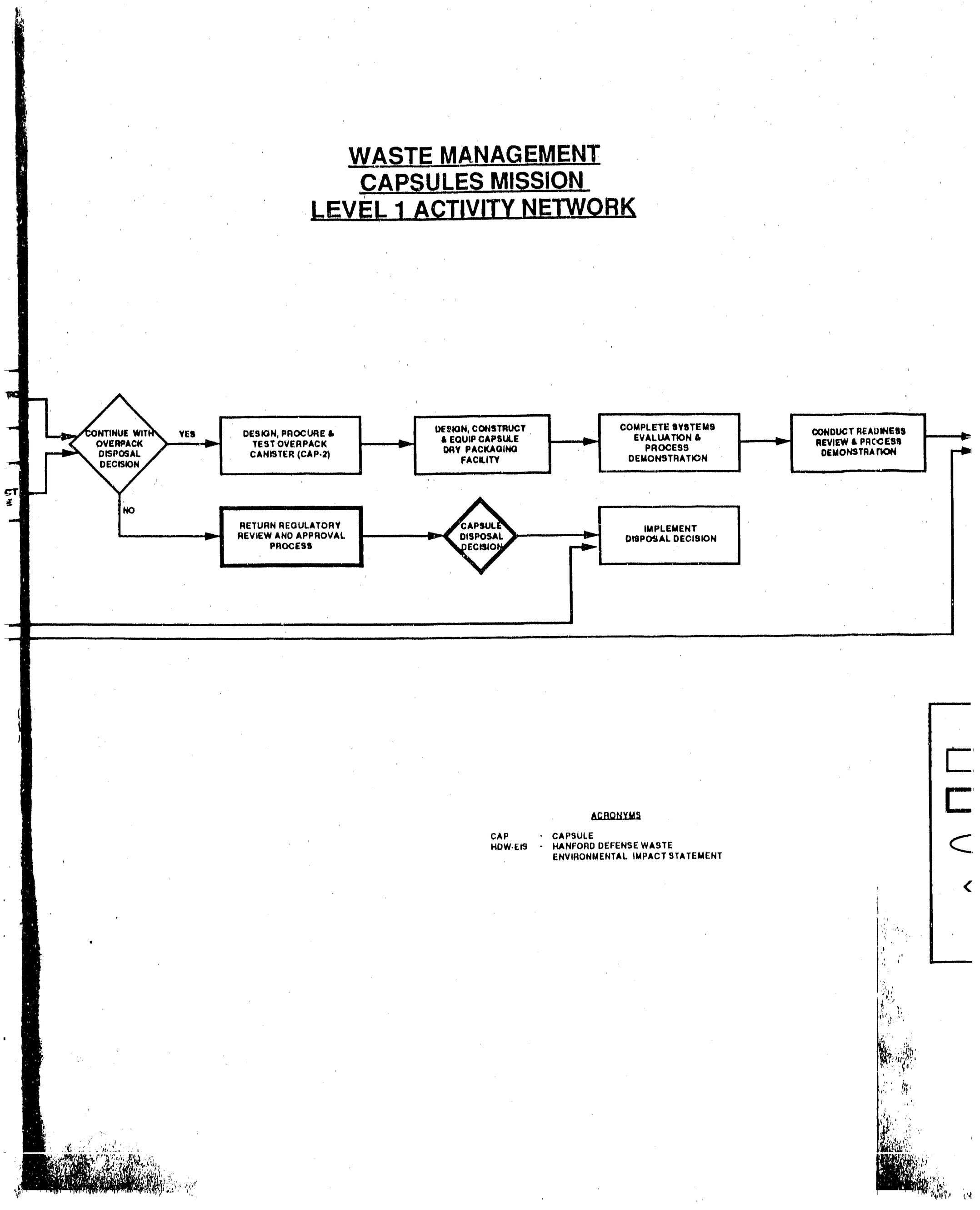




\subsection{SOLID WASTES}

\subsection{INTERIM STORAGE AND SURVEILLANCE}

Solid wastes can be divided into four parts: (1) retrievably stored and newly generated TRU waste; (2) LLW, nonhazardous; (3) mixed LLW, which is both radioactive and hazardous; and (4) $\mathrm{HW}$, which is not radioactive. The retrievably stored TRU waste will be treated for disposal. The newly generated TRU waste is being certified for future shipment to WIPP. Most of the LLW is being disposed of onsite except for small quantities stored for treatment. The mixed LLW is stored for future treatment and disposal. The HW is being stored for shipment to permitted commercial treatment and disposal facilities. Except for HW storage and the LLW burial grounds, these ongoing activities are being encompassed in the Hanford Central Waste Complex. The nonradioactive, nonhazardous waste, which will not be addressed in this section, is sent to landfills on the Hanford Site.

\subsubsection{Transuranic Wastes}

The TRU waste is generated at plutonium facilities, principally at the PFP and the PUREX Plant. The TRU waste is defined as wastes contaminated with alpha-emitting transuranium radionuclides with half-lives greater than twenty years and concentrations greater than $100 \mathrm{nCi} / \mathrm{g}$. Since 1970 , solid TRU waste has been stored for future treatment and shipment to a designated disposal facility. The WIPP was chosen as a demonstration disposal facility in the early 1980's and is now preparing to receive shipments. Most of the TRU waste is stored on asphalt pads. The TRU waste in retrievable storage is either contact-handled, where the dose rate at the container surface is less than $200 \mathrm{mrem} / \mathrm{h}$, or remote-handled. The remote-handled waste is in belowground caissons. The waste must be certified to WIPP waste acceptance criteria before shipment and some treatment may be required in the WRAP Facility.

In addition to the stored TRU solid waste, 9 sites (inactivated before 1970) and 24 contaminated soil sites are suspected to contain concentrations in excess of $100 \mathrm{nCi} / \mathrm{g}$. As a result of the $1988 \mathrm{ROD}$ on the HDW-EIS, the DOE has decided to undertake further development and evaluation on all but one of these sites in the interest of determining which remedial actions to implement. Development and evaluation associated with these sites, now referred to as part of the PPUS, are funded by the ER Program and addressed in Section 9.0. The one remaining site, designated 618-11, contains remote-handled TRU waste that will be exhumed for treatment.

Newly generated TRU waste receipts (post 1985) are expected to be about $200 \mathrm{~m}^{3} / \mathrm{yr}$ until all missions are completed. Practices are being developed that will allow the solid TRU waste generators to prepare a certified waste package acceptable for direct shipment to the WIPP. Until this practice is 
WHC - EP-0348

fully developed, interim treatment and storage is provided including examination and assaying of contact-handled TRU waste at the Transurarif Storage and Assay Facility. The generators of newly generated, remote-handled TRU waste will be certifying the waste at the source. The contact-handled certified waste is stored at Transuranic Storage and Assay Facllity and retained in a manner that will sustain certification until WIPP is ready to accept Hanford Site waste.

Small amounts of research reactor fuels and metallurgical samples are considered part of the stored, remote-handled TRU waste. These wastes are located in designated trenches or in caissons.

\subsubsection{Low-Level Waste, Nonhazardous}

LoW-level waste is radioactive waste that is not classified as HLW, TRU waste, spent nuclear fuel, or byproduct material. The current forecast for nonhazardous LI.W generation is $350,000 \mathrm{~m}^{3}$ from FY 1988 through FY 2017 , containing $30 \mathrm{kCi}$ of radioactivity (DOE 1989). Nonhazardous LLW, when properly certified, is currently being buried in earth-covered trenches (1andfills). Small volumes of LLW undergo voluine reduction in the $213-W$ Compactor Facility. As ensurance, volume reduction is provided by the WRAP Facility, additionally suitable LLW will be compacted before disposal. Minimization programs for LLW will be instituted at each generator, and requirements of DOE Order 5820.2A (such as phasing out cardboard containers) (DOE 1988) wi11 be implemented.

\subsubsection{Low-Level Waste, Mixed}

Mixed LLW is defined as LLW containing hazardous constituents. A comprehensive program has been implemented at the Hanford Site for all solid waste to attain full compliance with the RCRA and the Washington State Dangerous Waste Regulations, Washington Administrative Code (WAC) 173-303 (Ecology 1989). The program was initiated in FY 1987. The principal focus of the program concerns instituting procedures and practices at generator facilities to segregate the waste according to hazardous characteristics and minimize the quantity of waste.

The current forecast for mixed LLW generation is $10,000 \mathrm{~m}^{3}$ from FY 1988 through FY 2017 , containing $73 \mathrm{kCi}$ of radioactivity (DOE 1989). The mixed LLW is being segregated at the generator facilities and stored for possible future treatment in the WRAP Facility. Temporary storage areas, consisting of 13 small metal buildings located in the 200 West Area and the 305-B Building in the 300 Area, will be used through FY 1990. A 14,850-m² mixed LLW storage facility is being constructed as a series of four buildings that will be available between FY 1991 and FY 1993. The modified mission for the WRAP Facility will include treatment capabilities for mixed LLW. 
WHC - EP- 0348

High activity mixed LLW, referred to as drag-off waste because of the remote handling that is required, is being direct buried. It is generally considered to be waste in packages having surface dose rates greater than $200 \mathrm{mrem} / \mathrm{h}$. Other than Hanford Site waste, the reactors from defueled and deactivated nuclear vessels are received from the U.S. Department of the Navy and disposed of in designated trenches. In addition, some DOE mixed LLW is sent to the Hanford Site for storage or disposal (e.g., the defueled reactor from Shippingport, Pennsylvania, that arrived at the Hanford Site in Apri1 1989).

\subsubsection{Hazardous Waste, Nonradioactive}

The Nonradioactive Dangerous Waste Storage Facility and the 305-B Butlding are the only active facilities permitted for the storage of hazardous waste. The design of the Nonradioactive Dangerous Waste Storage Facility meets the requirements of the applicable codes, standards, and regulations for the safe handling, storage, packaging, and sampling of dangerous wastes (a designation used by Ecology). It is a permanent structure constructed of precast concrete.

Six storage cells are provided in the Nonradioactive Dangerous Waste Storage Facility for the interim storage of dangerous wastes. The cells are designated by waste type. The designation of these cells is not totally fixed, and some flexibility exists to redesignate cells as waste types and volumes change. The waste is stored for less than 90 days, in compliance with regulations, before shipment to commercial treatment and disposal facilities.

The 305-B Bullding is used for the collection, consolidation, and packaging of 300 Area mixed LLW and hazardous wastes. It is a two-story metal and concrete building formerly used for engineering R\&D. The building was recently upgraded to meet requirements for storage of hazardous wastes and mixed $L L W$.

\subsection{TREATMENT AND DISPOSAL}

An overview for TSD of solid wastes is shown in Figure 7-1. The WRAP Facility was conceptually designed to support examination, treatment, and packaging of the contact-handled TRU waste in preparation for shipment to the WIPP. The WRAP Facility mission is currently undergoing conceptual changes that will include several other feed streams, including the remote handled TRU waste, mixed LLW, and nonhazardous LLW. It has been estimated that about $40 \%$ of the stored TRU waste will be reclassified as LLW or low-level mixed wastes after assaying. Treatment will result in further reductions such that less than $10,000 \mathrm{~m}^{3}$ of certified TRU waste is expected for shipment to the WIPP. The Hanford Central. Waste Complex will include the modified WRAP Facility and several supporting facilities. 
Figure 7-1. Solid Waste Flowchart.
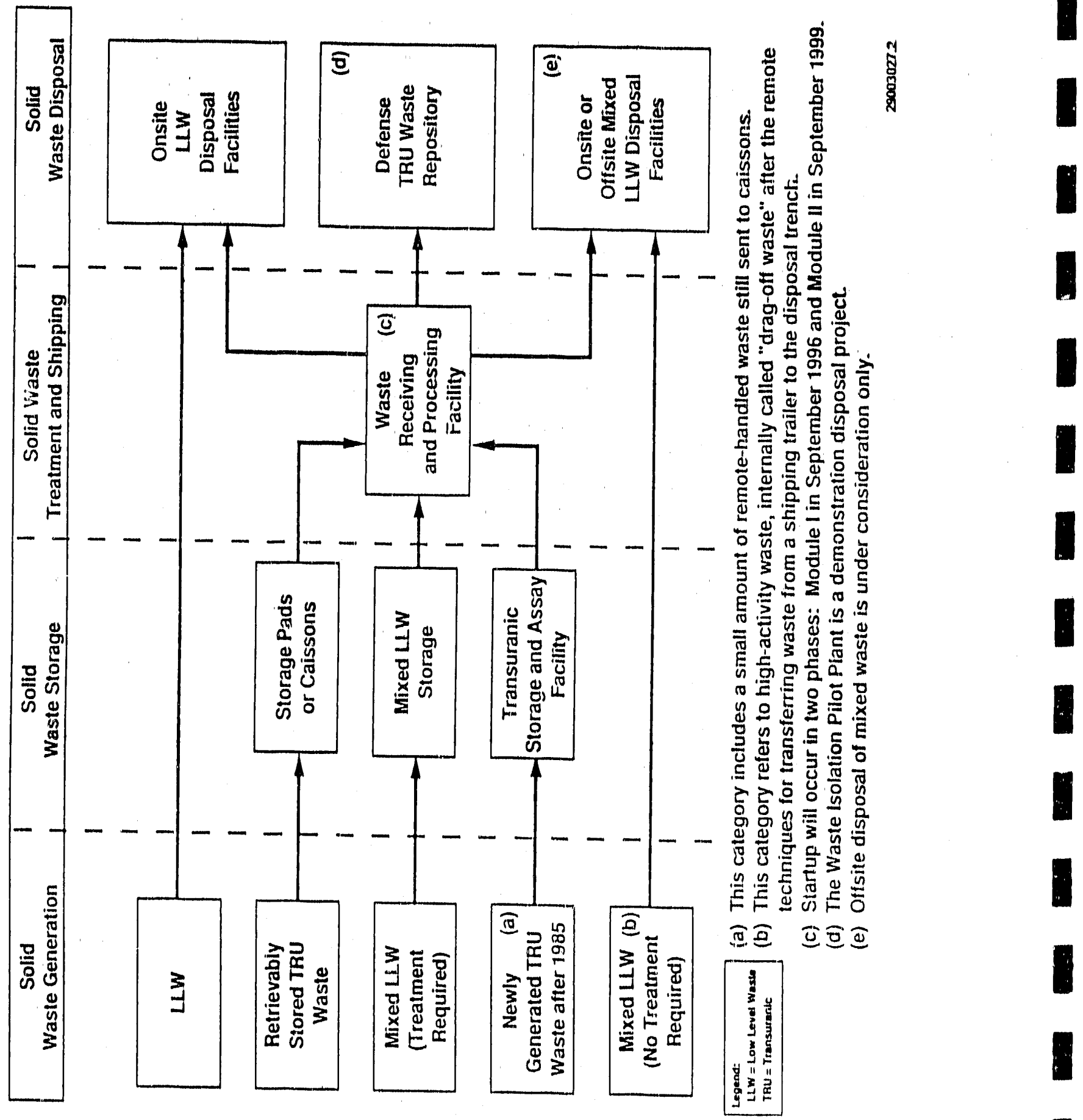
The WRAP Facllity will be constructed in two separate phases. One phase will provide waste package inspection, opening and sorting, waste segregation, compaction, repackaging, and certiflcation. Phase I becomes operational in september 1996. The second phase wlll provide the remainting treatment processes with emphasis on mixed waste. Phase II becomes opera. tional in September 1999. Treatment of TRU waste at the WRAP Facllity will result in three waste streams: certiffed TRU waste for disposal in WIPP, mixed LLW for permitted disposal, and LLW for onsite disposal. After the WRAP Facility is operational, all certified contact-handlod TRU solid waste packages will be shipped to the interim storage area of the WRAP Factlity and perlodically loaded onto the Transurantum Package Transporter for shipment to the WIPP. The certifled, remote-handled TRU waste will be shipped in the remote-handled TRU cask.

Additional treatment capabilities for Hanford Site wastes will be provided by the proposed Pactflc Northwest Laboratory (PNL) Hazardous Wast.e Treatment Facility, scheduled for completion in FY 1993. It will treat the small volumes of nonradioactive wastes resulting from the multiprogram R\&D activities at PNL. The treatment of small volumes of PNL mixed LLW WHIl be performed in the 325 Butldings.

There are no near-term plans for the remote-handled waste coritalned in catssons in the 618-11 site. Survetllance will continue for a decade or more and technology studies will be completed before retrteval efforts. An option that will be analyzed is to shlp all Hanford Site remote-handled waste to the Oak Ridge National Laboratory for treatment.

\subsection{ACTIVITY NETWORKS}

The Level 1 activity network for the disposal of radioactive solid waste is shown in Figure 7-2. The disposition of nonradioactive waste is discussed in Section 7.1. 


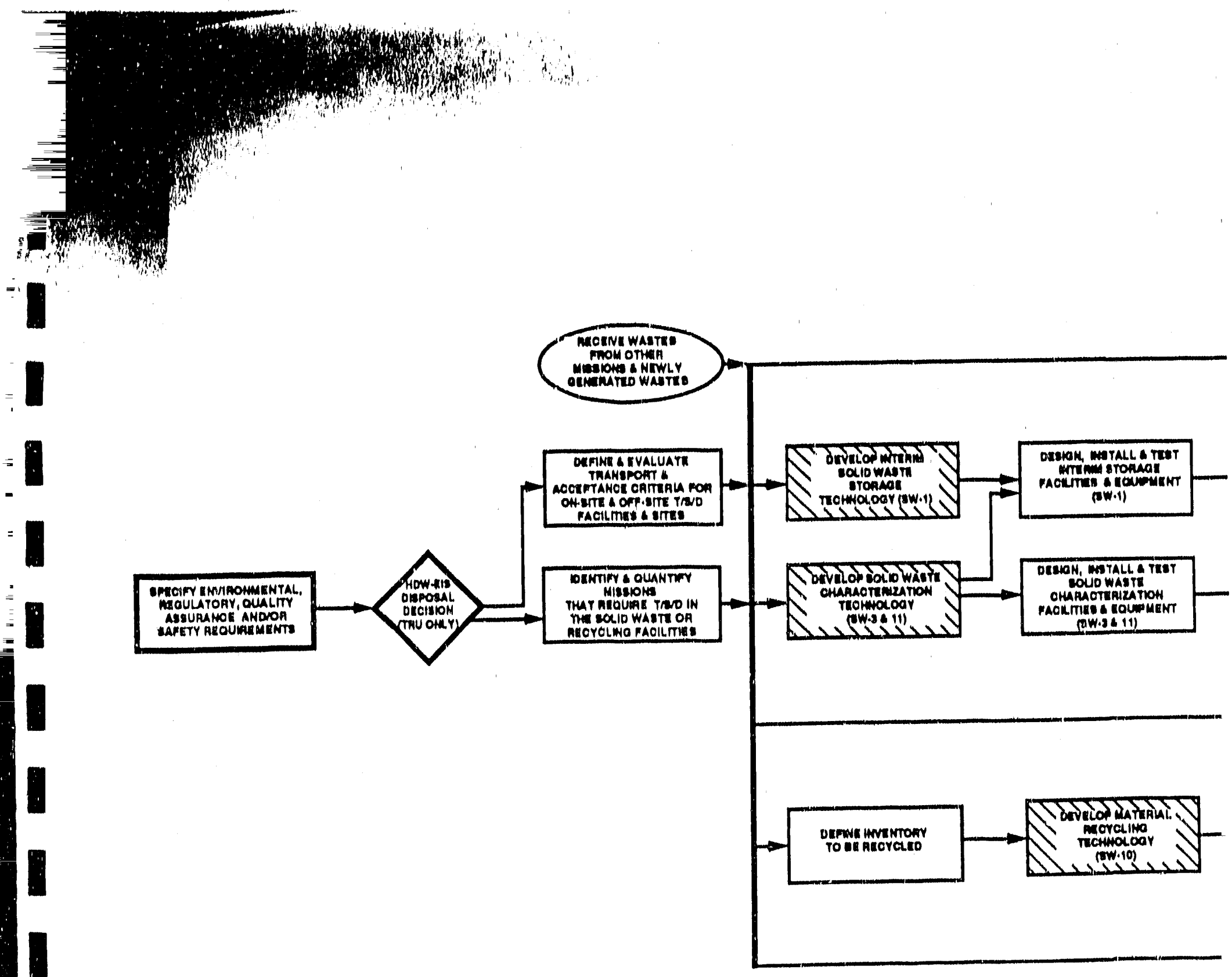



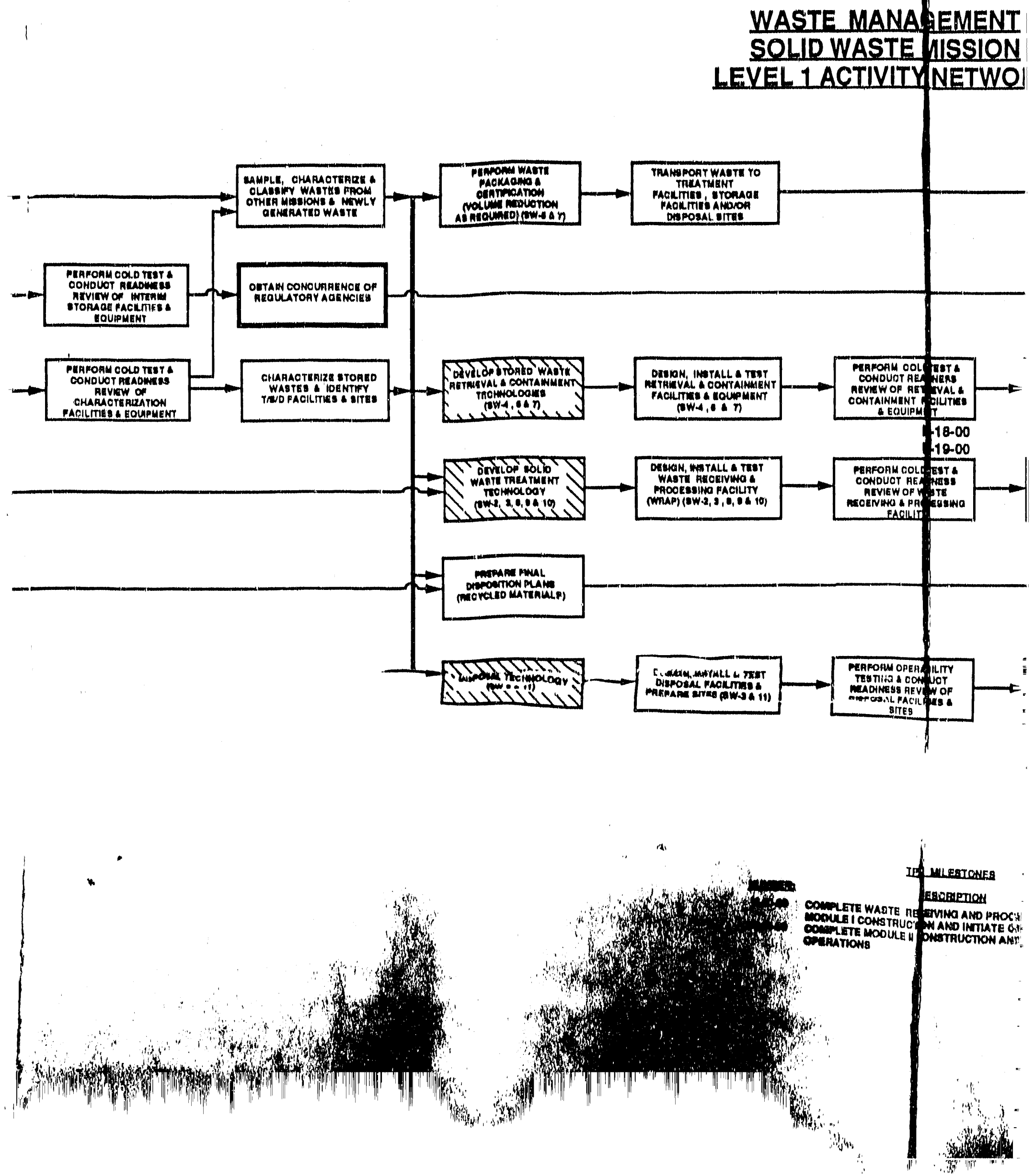


\section{EENT
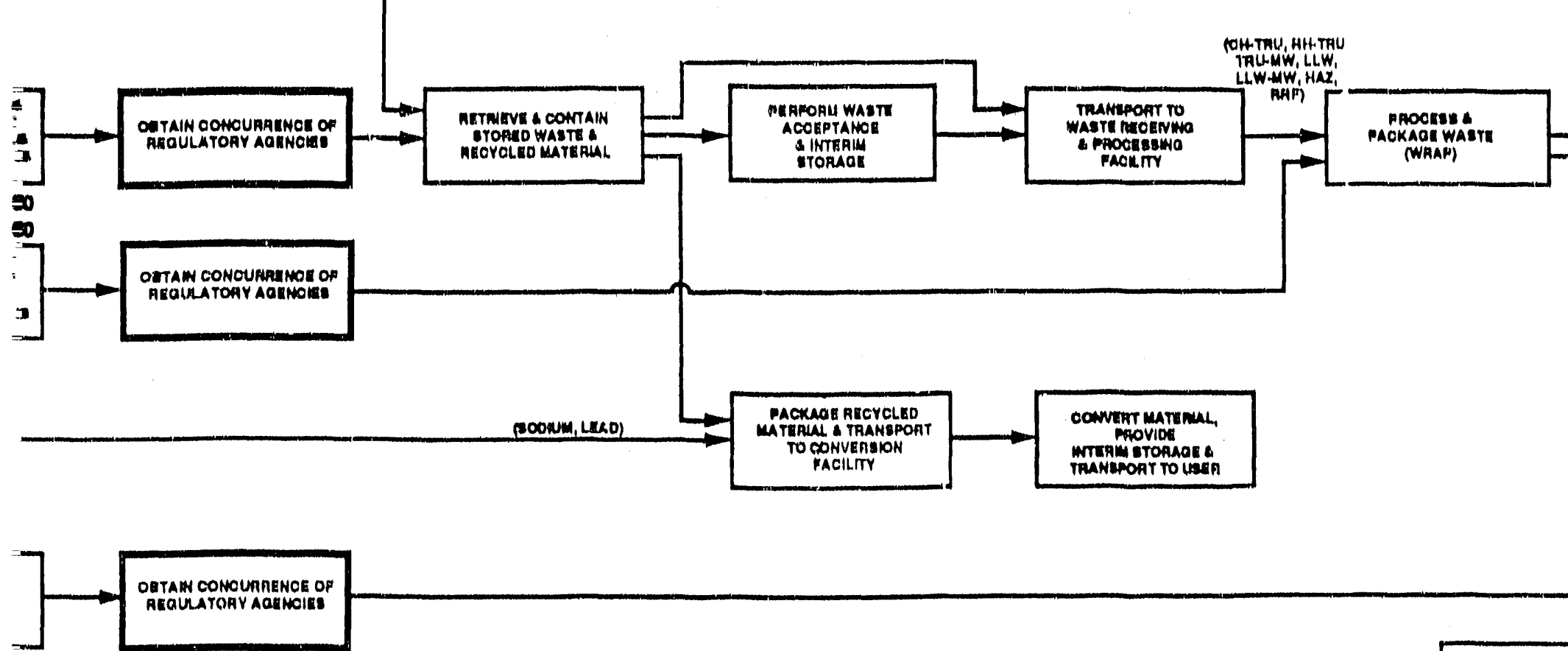

REQULATOAY AQHNOLE

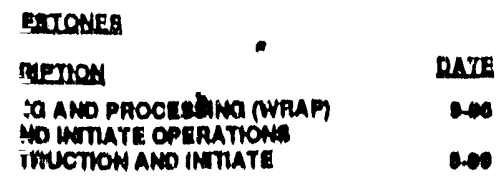

\section{Achearus}

CH - COHTACT MANCYLLD

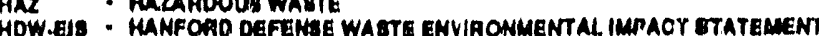

LLW - LOW LEVEL WAETE

LLWH : LWW GAEATEA THAN OLAM MOH

LIWH : LWW OAEATEA

MHW : MXED WAMTE

MH : AEmore MAWDLEO

IW - COUD WAETE

TRU - TRANEURANO WAaTH

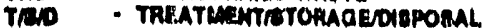

M. WAETE BOL L TON ML OT PI ANT

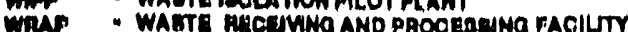




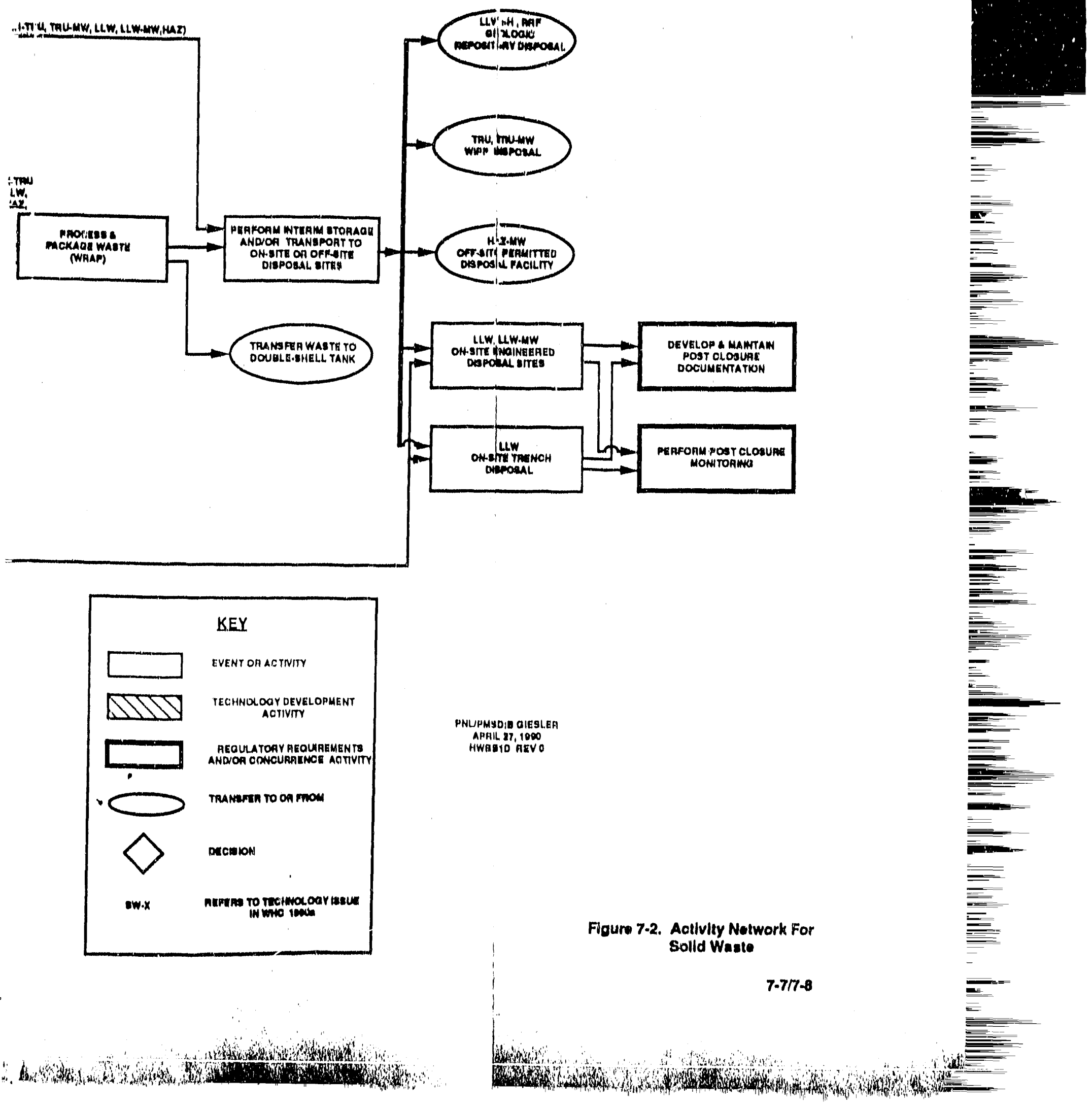




\subsection{LIQUID EFFLUENTS}

\subsection{PLANS TO DISCONTINUE CONTAMINANT DISCHARGES}

A comprehensive program is under way to discontinue the discharge of untreated, contaminated liquid effluents to the soll column. In response to a congressional request contained in an FY 1987 appropriations bill, a document entitled Plan and Schedule to Discontinue Disposal of Contaminated Liquids into the Soif Column at the Hanford Site (DOE-RL 1987) was issued and submitted to Congress in March 1987. Arinual updates to this plan were issued in September 1988 and September 1989 (WHC 1989).

Thirty-three liquid effluent streams have been identified for which action is required. The liquid effluent streams have been prioritized into 19 Phase 1 streams and 14 Phase II streams as shown in Table 8-1. The Phase I streams require more urgent attention based on radionuclide and chemical content, regulatory requirements, chemical spill potential, and waste disposal unit life expectancy.

The Phase I streams will have an alternative treatment and disposal systems implemented by June 1995. Phase II effluents will be addressed after Phase I. The treatment of Phase I streams, as depicted in Figure 8-1, includes (1) treatment based on best available technology economically achievable, (2) a secondary waste treatment system implemented in the Phase II WRAP Facility (September 1999 startup), and (3) treated effluent disposal options. The types of treatment will be identified through a best available technology evaluation and may consist of facility modification (source control) or end-of-pipe systems. Emphasis is being placed on source control.

The best available technology treatment systems will produce a lowvolume concentrated (secondary) wastestream that contains the removed contaminants. The need for further treatment of the secondary wastes will depend on whether they are liquid or solid, and on the nature and level of their radioactive and/or chemical contamination.

\subsection{ACTIVITY NETWORK}

The Level 1 activity network for discontinuing the discharge of contaminated liquid effluents to the soil column is shown in Figure 8-2. 
Table 8-1. Liquid Effluent Streams.

\begin{tabular}{|c|c|}
\hline Phase I Prioritization & Phase II Prioritization \\
\hline $\begin{array}{l}\text { B Plant process condensate } \\
\text { PUREX Plant ammonia scrubber condensate } \\
\text { N Reactor effluent } \\
\text { PUREX Flant process condensate } \\
\text { UO } 3 \text { Plant process condensate } \\
\text { PFP wastewater } \\
\text { PUREX Plant chemical sewer } \\
\text { B Plant chemical sewer } \\
222-S \text { Laboratory wastewater } \\
2101-M \text { Laboratory wastewater } \\
\text { T Plant wastewater } \\
300 \text { Area process wastewater } \\
\text { B Plant steam coridensate } \\
\text { PUREX Plant steam condensate } \\
\text { S Plant wastewater } \\
242-A \text { Evaporator process condensate } \\
2724-W \text { Laundry wastewater } \\
\text { 163-N Demineralizer wastewater } \\
\text { U0 } 3 \text { Plant wastewater }\end{array}$ & 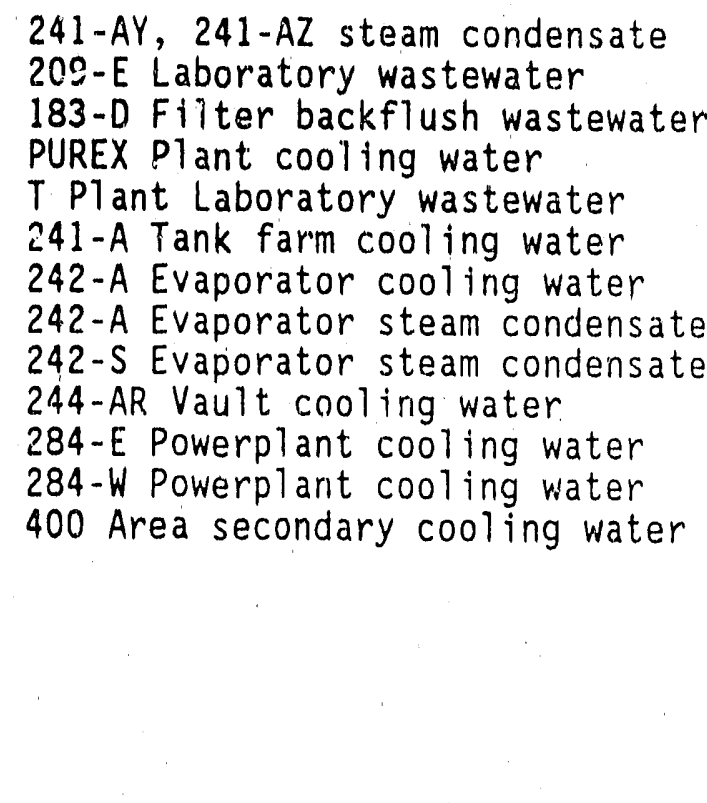 \\
\hline
\end{tabular}

PUREX = Plutonium Uranium Extraction. PFP = Plutonium Finishing Plant. 
WHC-EP-0348

Figure 8-1. Liquid Effluent Alternative Treatment and Disposal System.

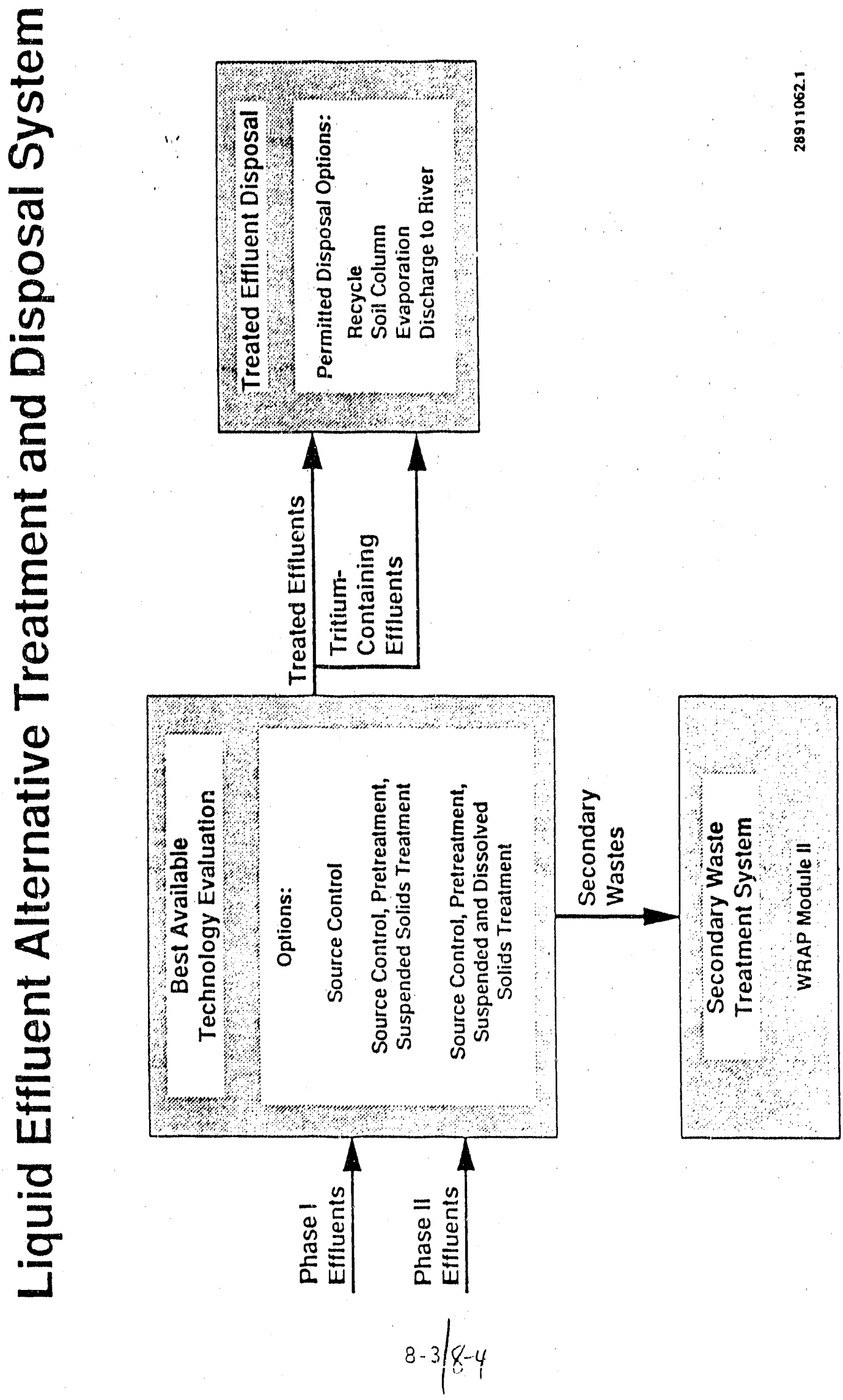




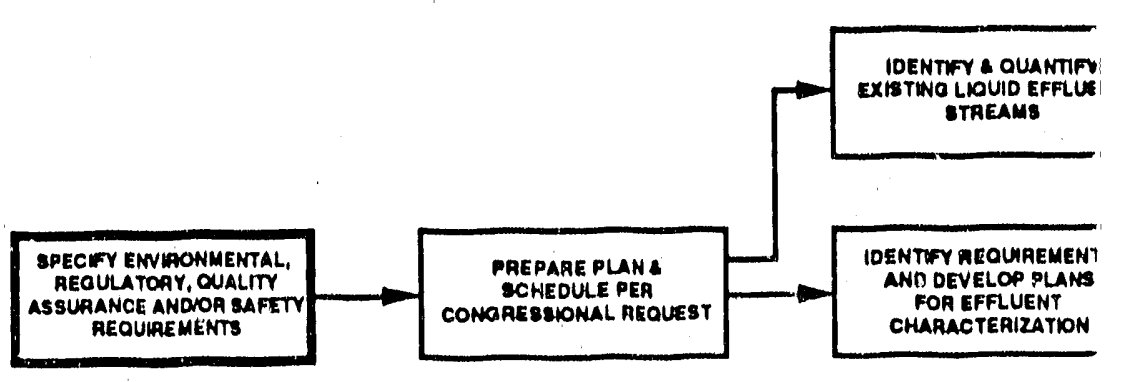

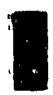

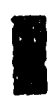

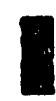

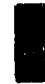

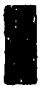

I

DIAE MENT

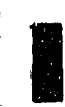

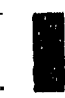

I

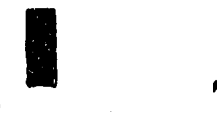

(2) 


\section{WASTE MANAGEMENT LIQUID EFFLUENT MISSION LEVEL 1 ACTIVITY NETWORK}

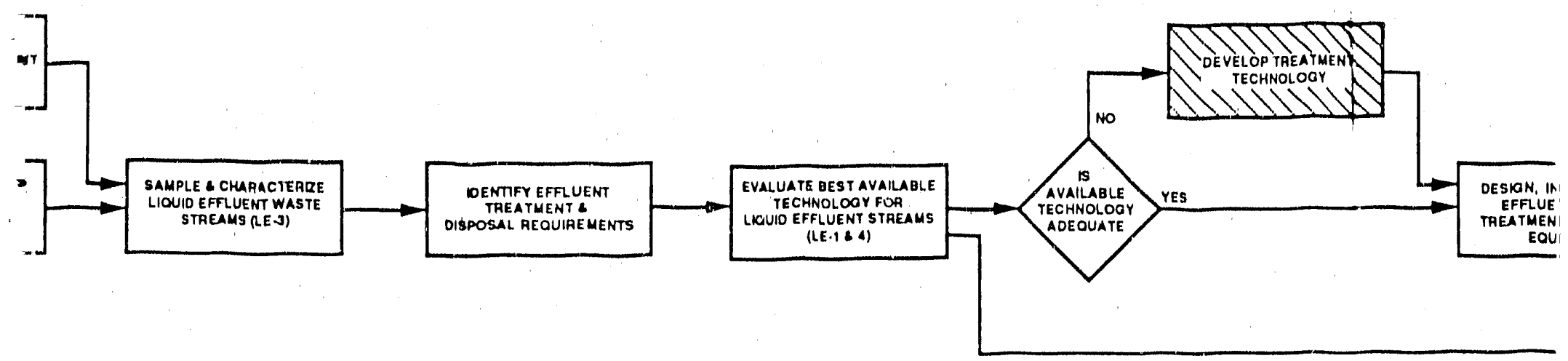

IPA MULESIOHES

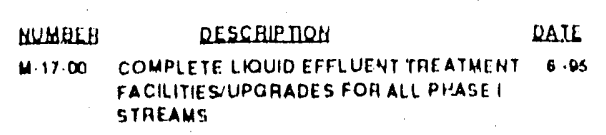

ACRONYMS

L. LVUID EFFLUENT

TEDS TAEATEDEFFLUENT DISPI WRAF WASTE AECEIVINO ANDPI 

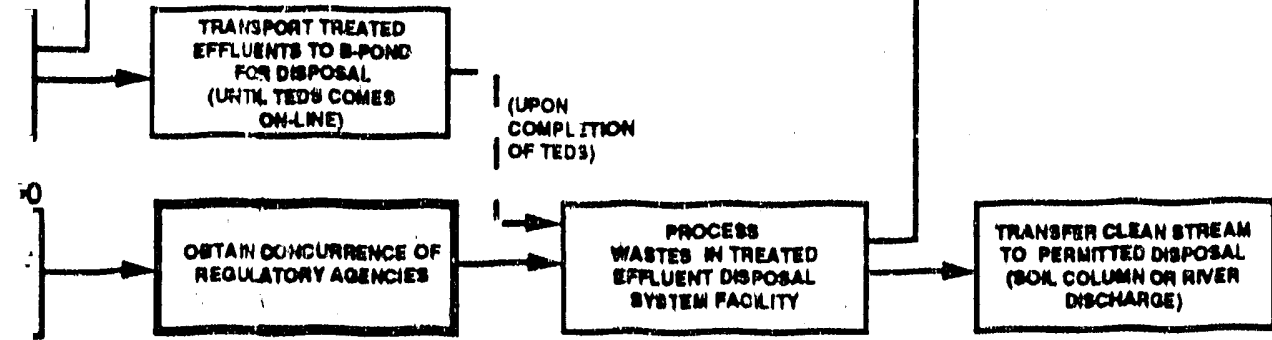

Figuro 8-2. Activity Notwork For Lquid Effluents

$20 / 8-6$

1

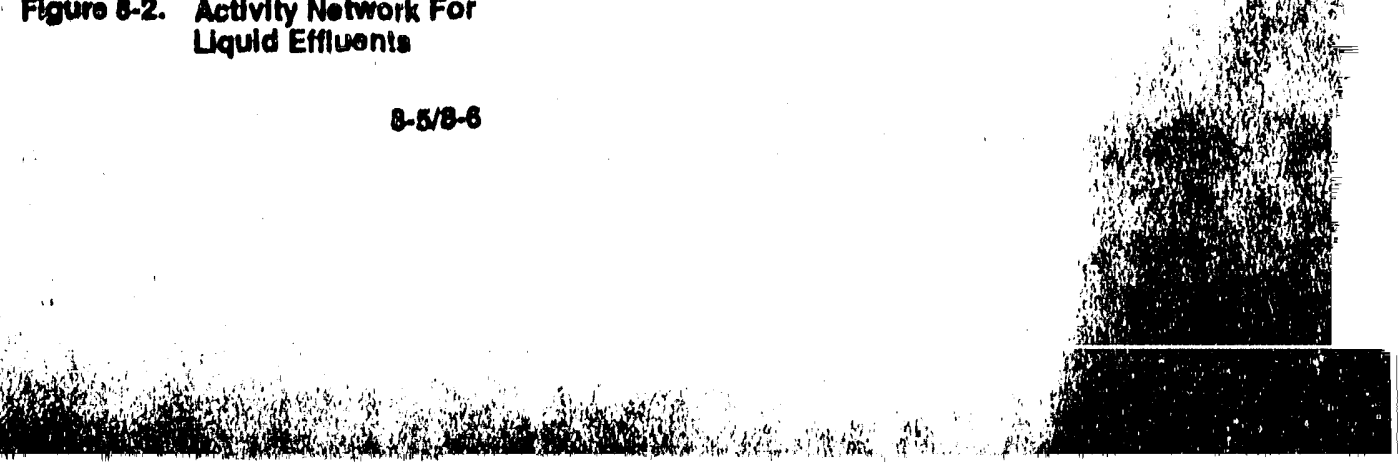


$W H C-E P-0348$

\subsection{PAST PRACTICE UNITS}

\subsection{BACKGROUND}

The Environmental Restoration Remedial Actions (ERRA) program was formally established in FY. 1988 at the Hanford Site to characterize and remediate PPUs. The primary objective of the program is to gather information sufficient to support an informed risk management decision regarding which remedy appears to be the most appropriate for a given site and then acting on this decision to implement the remedy. Secondary objectives include the following: (1) provide identification, emphasis, and accountability for al1 ERRA needs resulting from past HW activities; (2) provide an identifiable, coherent program by which all activities supporting ERRA can be coordinated and reported; and (3) prepare and manage the budgeting and scheduling of CERCLA and the Superfund Amendment Reauthorization Act (SARA), RCRA $3004(u)$, and selected TSD closure activities.

In order to carry out the mission and these objectives, the Hanford Site has been divided into four aggregate areas, 78 OU (Table 9-1), and about 1,500 waste management units. The waste management unit is the entity which is assessed, characterized, and remediated. Of the 1,500 waste management units which have been identified, approximately 1,127 are addressed by the ERRA program. The remainder of the waste management units are D\&D units, active TSD units, or are otherwise not applicable to the ERRA program. Assessment, characterization, and remediation activities on individual waste management units are carried out in groupings called OUs, which form the basis for planning, scheduling, budgeting, and establishing the working order and some of the applicable environmental restoration milestones for the DOE and the Tri-Party Agreement (Ecology et al. 1989).

\subsection{ASSESSMENT AND CHARACTERIZATION}

Assessment and characterization of PPUs consist of activities to identify potential contaminants, determine the nature and extent of contamination, specify cleanup requirements, and select remedial actions. In addition to contaminant levels and the extent of contamination, information is needed also to describe the geologic, hydrogeologic, and geochemical setting of each waste management unit. This allows predicting the fate and transport of contaminants to the environment and for assessing any potential risks.

The major assessment and characterization activities involve performing Remedial Investigations/Feasibility Studies (RI/FS) under CERCLA and performing RFI/CMS under RCRA. The process selecited for each OU shall be sufficiently comprehensive to satisfy the technical requirements of both statutory authorities and the respective regulations. 
Table 9-1. Hanford Site Environmental Restoration Remedial Actions Program Operable Units Listing.

\begin{tabular}{|c|c|c|c|}
\hline $\begin{array}{c}\text { Operable } \\
\text { unit }\end{array}$ & Category & $\begin{array}{l}\text { Operable } \\
\text { unit }\end{array}$ & Category \\
\hline $\begin{array}{l}1100-E M-1 \\
300-F F-1 \\
300-F F-5 \\
200-B P-1 \\
100-H R-1 \\
100-H R-3 \\
100-D R-1 \\
100-B C-1 \\
100-B C-5 \\
100-K R-1 \\
100-K R-4 \\
100-N R-1 \\
100-F R-1 \\
100-N R-3 \\
200-U P-2 \\
100-B C-2 \\
200-D P-5 \\
100-D R-2 \\
200-Z P-1 \\
100-K R-2 \\
200-B P-4 \\
200-B P-11 \\
200-P O-2 \\
200-P O-5 \\
100-B C-3 \\
100-B C-4 \\
100-D R-3 \\
100-F R-2 \\
100-H R-2 \\
100-K R-3 \\
100-N R-2 \\
100-I U-1 \\
200-B P-2 \\
200-P O-1 \\
200-P O-4 \\
200-S 0-1 \\
200-T P-1 \\
200-T P-2 \\
200-T P-4 \\
\end{array}$ & $\begin{array}{l}C P P \\
C P P \\
C P P \\
C P P \\
R P P \\
R P P \\
R P P \\
C P P \\
C P P \\
C P P \\
C P P \\
R P P \\
C P P \\
R P P \\
C P P \\
C P P \\
C P P \\
R P P \\
C P P \\
C P P \\
\\
R P P \\
\\
\\
C P P \\
C P P \\
R P P \\
R P P \\
C P P\end{array}$ & $\begin{array}{r}200-Z P-2 \\
200-I U-3 \\
300-F F-2 \\
300-F F-3 \\
100-I U-2 \\
100-I U-3 \\
1100-E M-2 \\
1100-E M-3 \\
1100-I U-1 \\
200-B P-10 \\
200-B P-3 \\
200-B P-6 \\
200-B P-8 \\
200-B P-9 \\
200-N O-1 \\
200-P O-6 \\
200-R O-1 \\
200-R O-2 \\
200-R O-3 \\
200-T P-3 \\
200-U P-1 \\
200-Z P-3 \\
200-I U-4 \\
300-I U-1 \\
300-F F-4 \\
100-I U-4 \\
100-I U-5 \\
200-S S-1 \\
200-S S-2 \\
200-I U-1 \\
200-I U-6 \\
200-I U-2 \\
200-I U-5 \\
200-B P-7 \\
200-P O-3 \\
200-R O-4 \\
200-T P-5 \\
200-T P-6 \\
200-U P-3 \\
\end{array}$ & $\begin{array}{l}\text { RPP } \\
\text { RPP } \\
\text { RPP } \\
\text { RPP } \\
\text { RPP } \\
\text { RPP }\end{array}$ \\
\hline
\end{tabular}

RPP $=$ RCRA past practice.

$C P P=$ CERCLA past practice.

Those operable units that are not in either category have yet to be designated. 
WHC-EP- 0348

The NEPA also has requitrements for documentation of environmental revtews assoctated with hazardous substances remedial action projects. The DOE has issued Notice urder 5400.4, Integration of Environmental Compliance Processes (DOE 1989a), which establitshes the pollcy for meeting the requirements of the NEPA and RI/FS processes for remedial actions under CERCLA. The intent of this policy is to integrate the requirements of NEPA with the planning and environmental review procedures of the CERCLA RI/FS process so that al1 such procedures run concurrently rather than consecutively.

Each RI/FS or RFI/CMS is an therative process that requires a phased approach to specify cleanup requirements, and select and evaluate remedial actions. The first task in each RI/FS or RFI/CMS is the preparation of a work plan that outlines the activitles to be performed. This plan is prepared in draft by the DOE operating contractor and its subcontractors. The DOE, EPA, and Ecology review the plans and provide comments which are incorporated into a second revision that is circulated for public review. After pubitc review, comments are tncorporated and the work plan is published. The reviews can have considerable impact on the scope of the work plan.

As the work plan for each OU is developed, the schedule for the RI/FS or RFI/CMS activities is created and modiffed to reflect the requirements for that $0 U$. Current schedules that are being used to plan activities for the OUs in lieu of specific work plan schedules are success orlented and have no contingency in the critical path activities. They are based on a 60-mo duration for the RI/FS activittes, including work plan preparation and approval, and represent a schedule compromise with the EPA and Ecology. Although a March 1988 generic RI/FS guidance document indicated that a 72-month RI/FS cycle was probably optimistic, the EPA and Ecology are willing to accept the 60-mo RI/FS duration unt 11 more specific information is available for each oU.

With an terative RI/FS or RFI/CMS process, numerous review cycles, and the uncertainties mentioned above, the confidence in cost and schedule estimates will remain low unt 11 additional experience is gained with RI/FS or RFI/CMS activities at the Hanford Site.

Assessment and characterization are implemented in several phases. The adequacy of existing information is first assessed; field investigations are then conducted if additional data are needed. These data are used to assess potential remedial actions for a site. The most appropriate course of action for a site is determined through a comparative analysis of each option as to technical feasibility and other factors (including cost effectiveness) in meeting cleanup requirements.

\subsubsection{Preliminary Ascessment and Site Inspection}

An earliter preliminary assessment and site inspection (PNL 1988) supported the nomination of the Hanford Site to the National Priorities List and completion of the informational requirements of the federal agency docket. 
WHC-EP-0348

The hazard-ranking system evaluation of CERCLA inactive waste sites at the Hanford Site was a part of the preliminary assessment process. The assess int activities are complete and no further action is planned for the ERRA Program.

\subsubsection{Investigations and Studies}

Under the Try-Party Agreement, 19 OUs have been designated as CERCLA PPUs, 15 OUs have been destgnated as RCRA Section $3004(u)$ PPUs, and 44 OUs have yet to be destgnated as etther RCRA or CERCLA. Six of the OUs that have been designatied as RCRA Section 3004(u) PPUs are assoctated with SSTs and are addressed in section 5.0. The schedules for preparing and submitting CERCLA RI/FS or RCRA RFI/CMS work plans and for conducting investigations and studies are stipulated in the Trt-Party Agreement. As of Apri1 1, 1990, 13 work plans have been inttlated; of these, 7 have been sent to EPA and Ecology for revtew and 2 have been approved by the EPA and Ecolog,y and are undergoing investigation. The following description of the four-part investigation and study activities uses a genertc work description approach:

- Scoping Studies--Scoping studies wl11 be started 4 to 9 mo prtor to inttlating the preparation of an RI/FS or RFI/CMS work plan. The main purpose of this study is to provide information for preparing the oU Site Description Document, a key part of the $\mathrm{RI} / \mathrm{FS}$ or RFI/CMS work $\mathrm{plan}$.

- Work Plans--Work plans must be prepared and approved by the EPA and Ecology before the majority of the remedial investigation work is started on all of the OUs to be assessed and characterized under the RI/FS and RFI/CMS process. The work plan describes the OU and the steps and processes that must be undertaken to arrive at a selected remedy.

- Investigation--An investigation, consisting of efther a remedial investigation (CERCL.A) or RCRA facilfty investigation, is to be conducted on each OU and will be spectfically defined by tts respective work plan. The investigation will normally be conducted in two major phases. At the conclusion of each phase of the investigation, a report wt1l be prepared for EPA and Ecology review.

- Study--A study, consisting of an feastbility study (CERCLA) or corrective measures study (RCRA), is to be conducted on each OU and $w 111$ be defined by its respectlve work plan. The studies on each ou w111 be carried out in three phases. The objective of the Phase I study is to start the definition of cleanup objectives and the development of remedial alternatives. The objective of the Phase II study is to cont inue the development of remedial alter. natives, to screen remedial alternatives, and to prepare the Phases I and II study report for review and approval by the EPA and Ecology. The objective of the Phase III study is to evaluate 
the remedial alternatives; to prepare the Phase III study report; to prepare the proposed plan for EPA, Ecology, and publtc revtew; and to obtain EPA and Ecology approval. Upon approval of the proposed plan, an ROD Will be prepared and issued by the EPA and Ecology so that remedial actions on the ou can proceed.

In conjunction with the four-part investigation and study activities, discussion with the EPA and Ecology have indicated a need to address interim remedial actions. These actions would resolve immediate problems. Examples include groundwater removal and treatment, and source term remediation.

\subsubsection{Environmental Restoration Remedial Actions Program Support}

The objective of ERRA Program Support is to provide overall support in a varlety of areas including community relations, media relations, records management, technical data management, configuration management, quality assurance, and complitance with the requitrements of the NEPA. Also included in the ERRA Program Support is the funding for Ecology support of the Tri-Party Agreement.

Community and media relations efforts include planning and implementation of the activities identifled in the community relations plan for the Hanford Site (Ecology et al. 1989) as well as the spectfic communtty relations activtties required to meet the Tri-Party Agreement. Records, data, and config. uration management efforts ensure compliance with applicable requirements for validation, retention, retrieval, and use of records and data. The $Q A$ activities in ERRA Program Support include overall QA planning, documentation for the Hanford ERRA Program, and development and maintenance of a QA manual. The NEPA support to the Hanford Site EPRA Program includes NEPA compliance planning as well as preparation of a proposed programmatic EIS.

\subsection{ACTIVITY NETWORK}

The Level 1 activity network for PPUs is shown in Figure 9-1. 


\section{ENVIRONMENTA \\ SURPLUS FACUI \\ LEVEL 1 ACTIV}

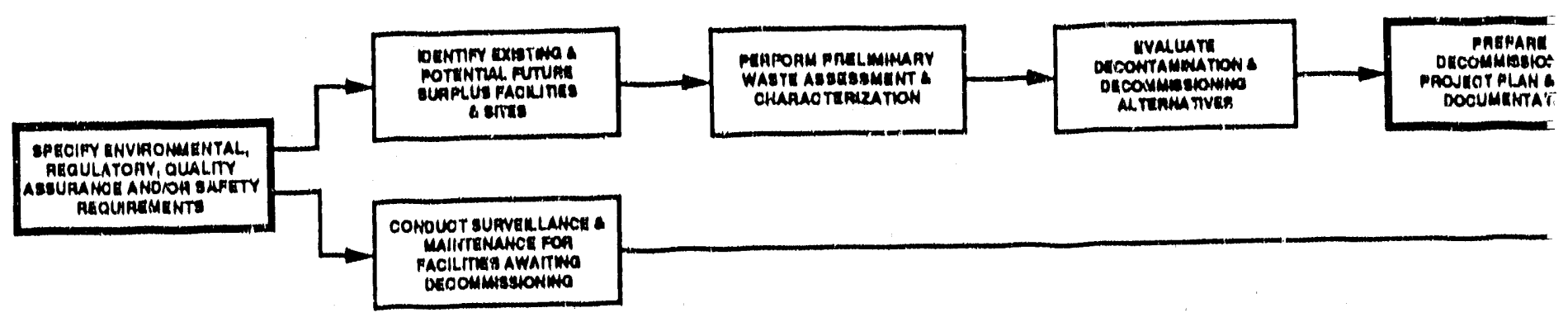




\section{ONMENTAL RESTORATION DLUSFACILITIES MISSION EL 1 ACTIVITY NETWORK}

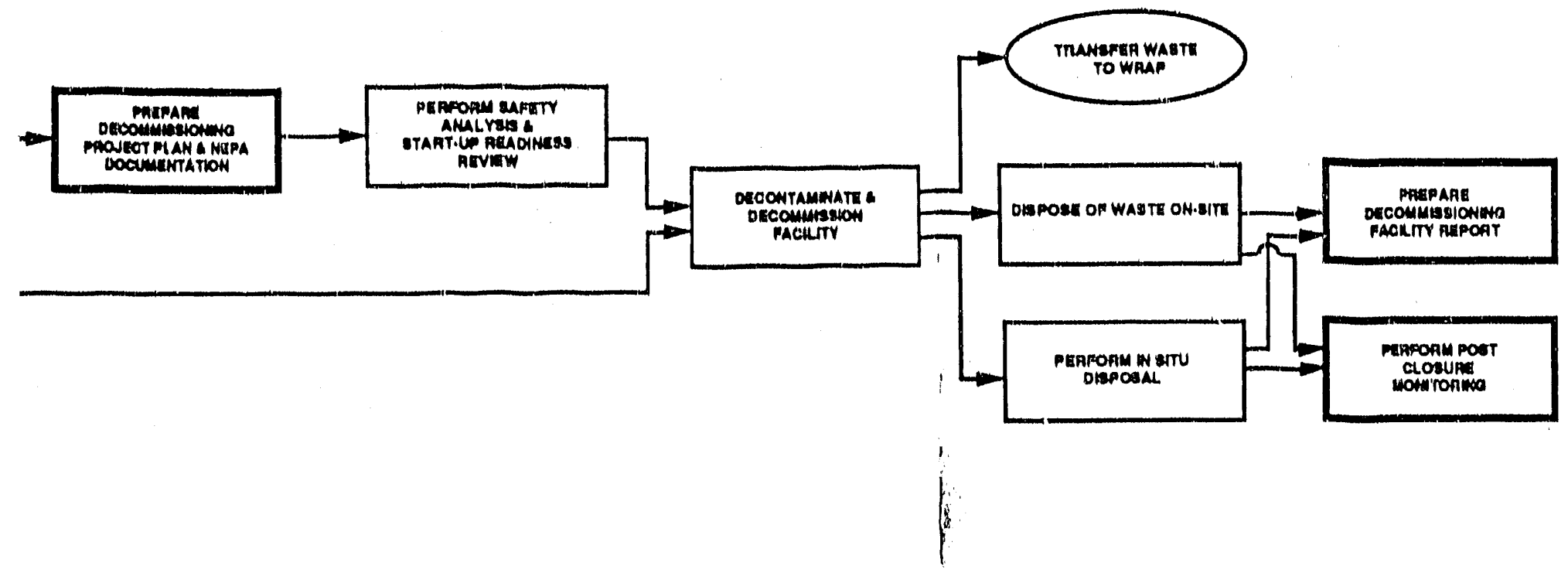

ACBOMYMS

NEPA - MATIONAL EHVIRONMENTAL POLICY ACT

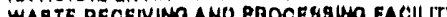

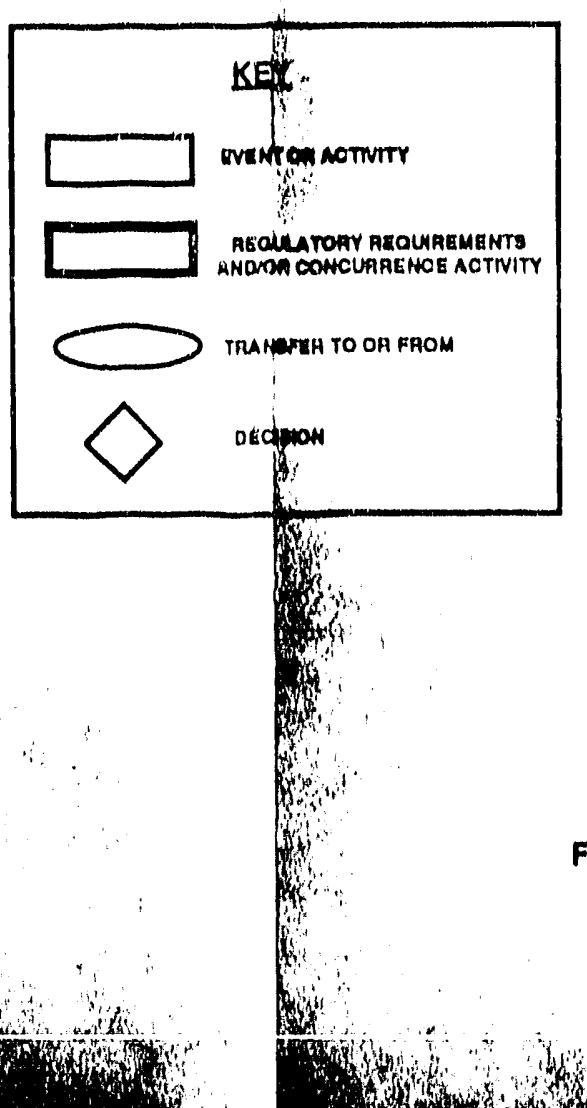

PNLPMSO: VA MARTINIUA APFIL 27, 1000

HWCQID HEV O
Figura 10.1. Aotivity Network For surplun Faallitios

$10-3 / 10-4$ 
WHC -EP- 0348

\subsection{DECONTAMINATION AND DECOMMISSIONING OF SURPLUS FACILITIES}

\subsection{HANFORD SITE SURPLUS FACILITIES}

About 115 radioactively contaminated structures, including surplus production reactors, chemical process buildings and structures, and ancillary structures, are included within the scope of the surplus facility program. The program is divided into three major activity categories: (1) program management and support, (2) maintenance and surveillance, and (3) D\&D. The following paragraphs describe the activities which will take place within the FY 1990 to FY 1995 time period.

Program management and support will increase commensurate with the size and numbers of structures that will be undergoing D\&D at any one period of time. Specific action covered by Program Management and Support include program management, planning and scheduling, $Q A$, and records and data management.

Surveillance and maintenance will continue to ensure that radioactive contamination is controlled in accordance with DOE orders regarding environmental protection, safety, and health protection, and to keep facilities in a state which prevents them from deteriorating.

Activities under way in D\&D include activities on portions of the 183-H Solar Basins cleanup in accordance with the interim closure plan; D\&D activities on the 201-C Strontium Semiworks Complex and 100 Area ancillary facilities; and preparation of the Draft Environmental Impact Statement, Decommissioning of Eight Surplus Production Reactors at the Hanford Site, Richland, Washington (DOE 1989b) for the eight shut down 100 Area reactors. Future D\&D activities within the FY 1990 to FY 1995 time period include the continuation of the foregoing activities, plus the possible start of D\&D on the 100 Area Reactors and 100 Area Effluent Facilities.

\subsubsection{Surveillance and Maintenance}

The surplus facilities program includes a program of scheduled surveillance and maintenance. Surveillance and maintenance functions have two purposes: (1) ensure that radioactive contamination is controlled in accordance with DOE Orders regarding environmental protection, safety, and health protection and (2) provide the security controls and safety evaluations and enhancernents recessary to minimize potential hazards to the public and site personnel. The maintenance and surveillance activities include routine radiological monitoring, access control, and repairs to the buildings and structures. 
Because the cost of surveillance and maintenance are high and will increase as the shut down facilities continue to deteriorate, long-term solutions are currently being sought for managing the facilities. Possible alternatives range from decontaminating the facilities for possible reuse to complete dismantlement and restoration of the site.

\subsubsection{Surplus Reactors}

The 100 Area Reactor decommissioning project includes a total of eight radioactively contaminated graphite-moderated reactors, their housing structures, and spent-fuel storage basins. These facilities were constructed between 1945 and 1955 and are in a condition that requires routine repairs to control residual radioactive material. The DOE has released an EIS for public review before selecting a method of decommissioning.

\subsubsection{Other Surplus Facilities}

The 100 Area effluent systems decommissioning project includes radioactively contaminated systems in the 100 Areas that supported operation of the reactors. These systems require routine surveillance and maintenance. They are scheduled to be characterized and their D\&D method determined beginning in FY 1991.

The 100 Area ancillary facilities decommissioning project includes radioactively contaminated facilities in the 100 Area that supported operation of the reactors. These facilities require routine repair to control residual radioactivity. They will be decommissioned.

The 201-C Strontium Semiworks Plant is a surplus process pilot plant. The D\&D of this facility has been ongoing since FY 1984 and is scheduled to be completed in FY 1993.

The 224-B Building is a surplus plutonium concentration facility. This project will decontaminate the facility to prevent the possible release of radioactive contamination to the environment, remove surplus equipment, and make the facility available for reuse.

\subsection{ACTIVITY NETWORK}

The Level 1 activi, network for the remediation of PPUs is shown in Figure 10-1. 


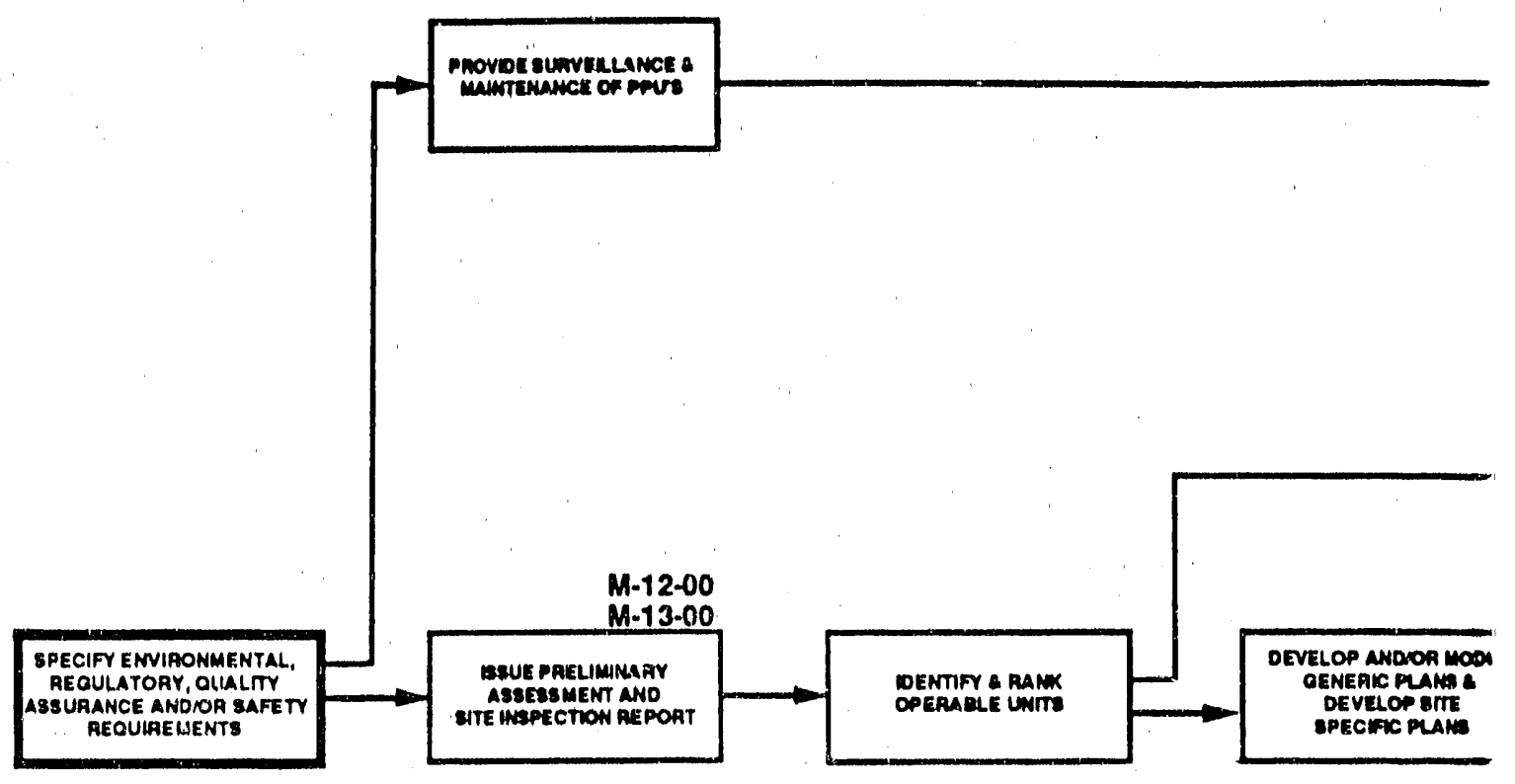




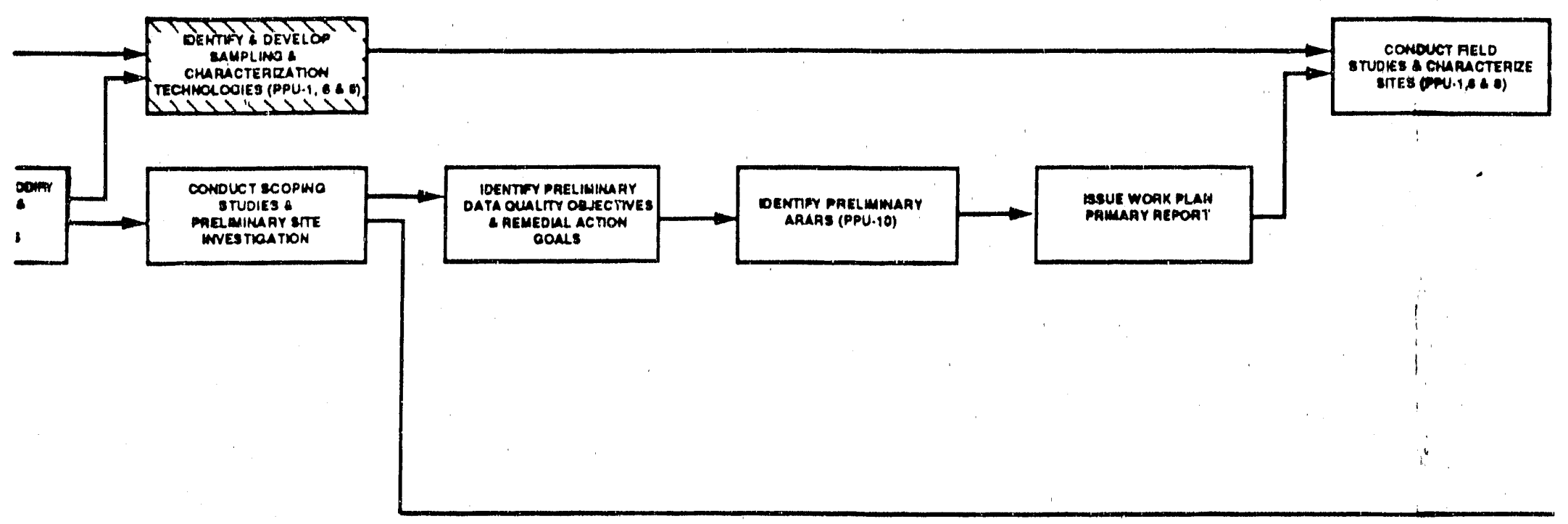

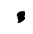

IRA MULESTOMEg

$\checkmark$

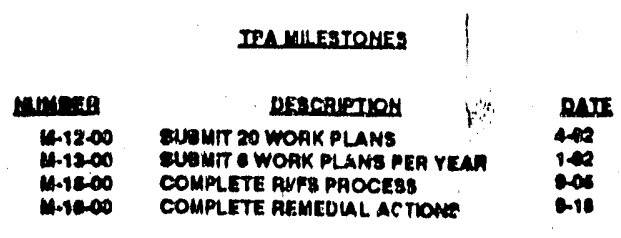

1

$\therefore \quad \therefore \quad \therefore$

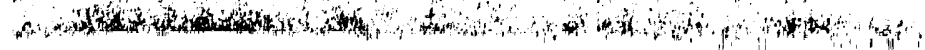




\section{ENVIRONMENTALRESTORATION PAST PRACTICE UNITS MISSION LEVEL 1 ACTIVITY NETWORK}

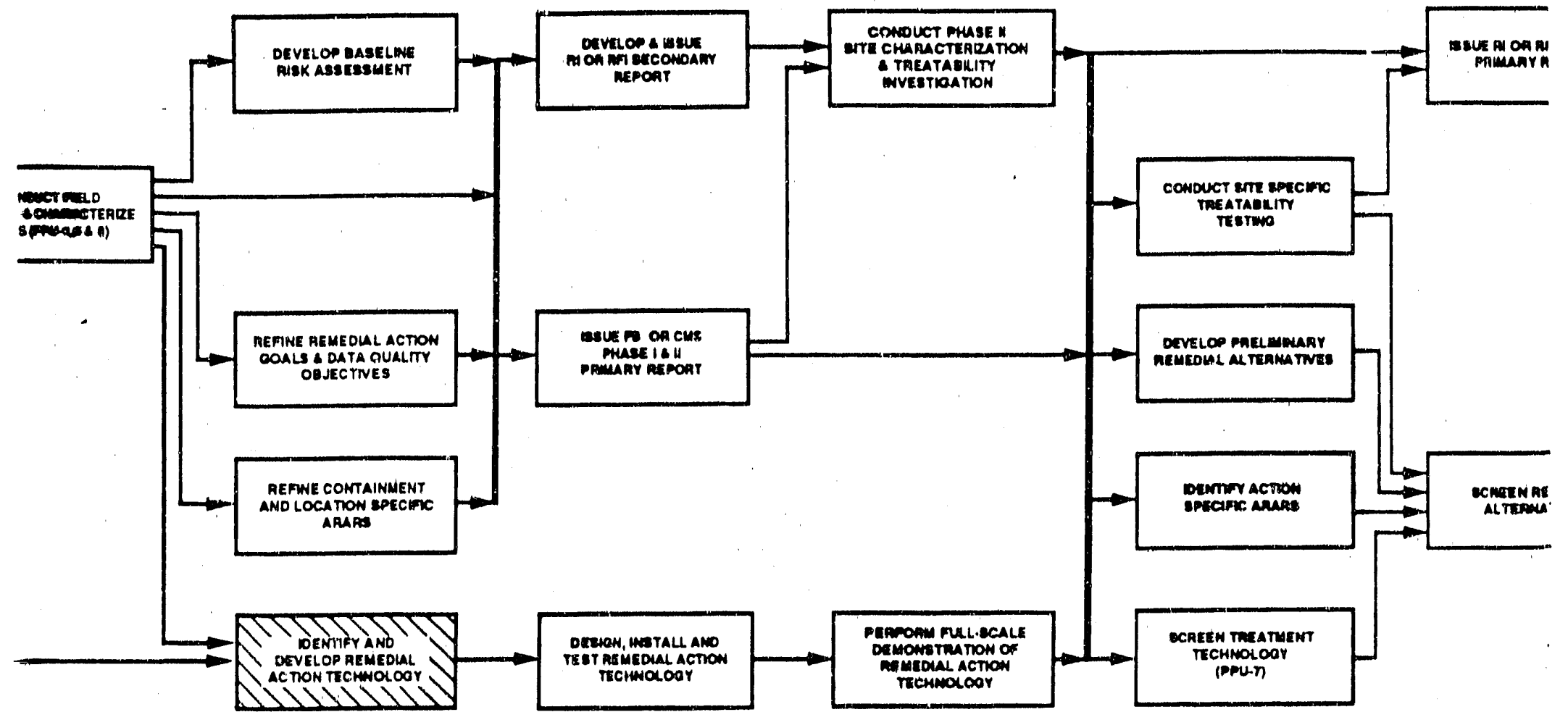




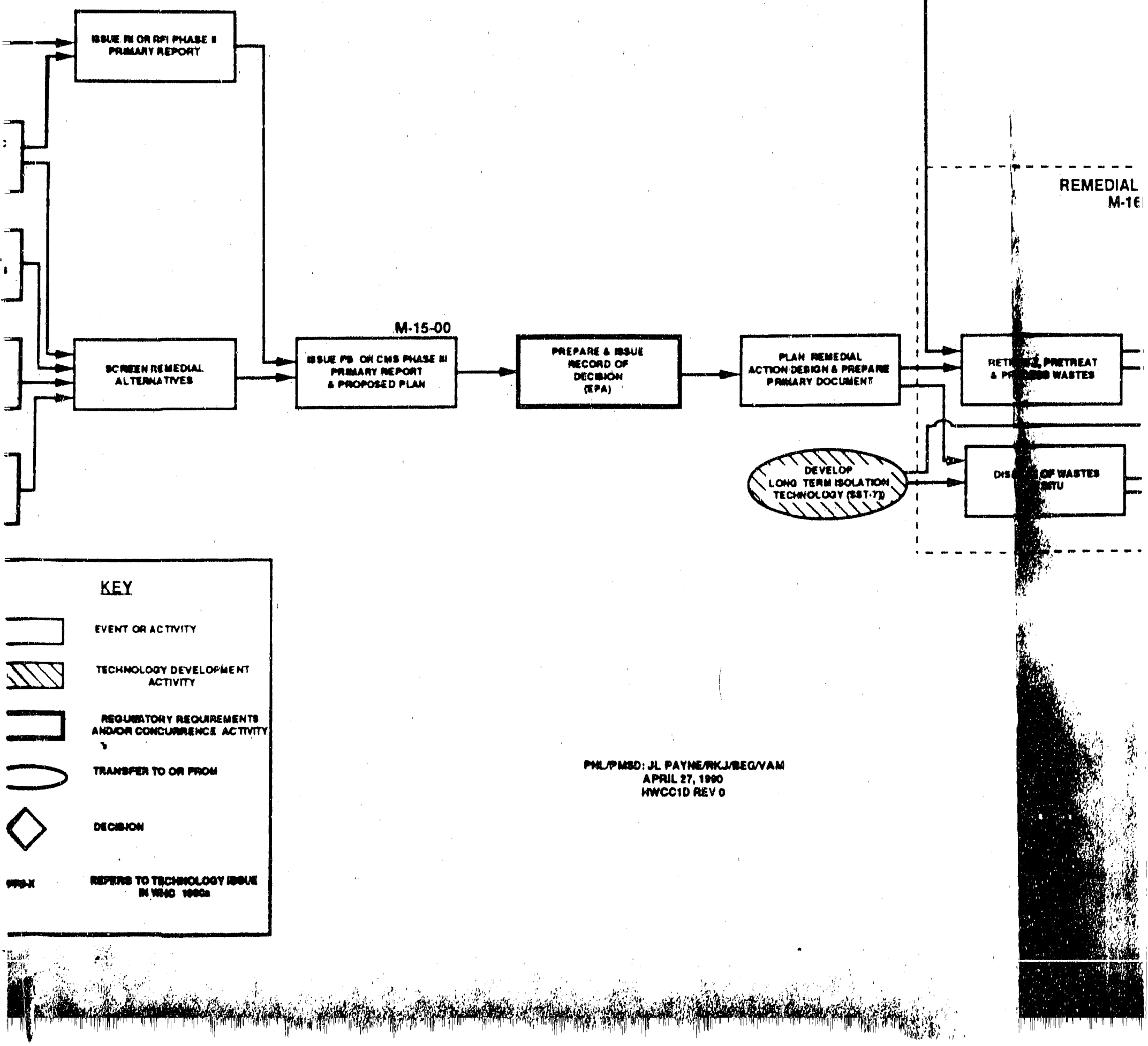




\subsection{SUPPORTING ACTIVITIES}

Supporting activities are those that are common to each of the waste management missions and that may influence or interact with the Environmental Restoration Program. For the purposes of this document, supporting activities have been divided into six areas: (1) continulty of operations, (2) National Envirorimental Policy Act (NEPA) actions, (3) corrective activities, (4) waste minimization, (5) laboratory support, and (6) environmental monitoring and control.

\subsection{CONTINUITY OF OPERATION}

Continuity of operations provides a safe, minimum level of operations and consists of a distinct funding category. Activities include management, surveillance, and maintenance of facilities and disposal sites, as well as preparedness of facilities for receipt, handling, and interim storage of radioactive, hazardous, and mixed wastes. Because of the continuity afforded by this activity, it is not identified as a distinct activity on the networks of the missions.

\subsection{NATIONAL ENVIRONMENTAL POLICY ACT ACTIONS}

Regulations promulgated pursuant to NEPA and corresponding DOE orders and guidance require DOE to evaluate the environmental impacts for any action significantly affecting the quality of the human environment. The level and extent of the evaluation on environmental impacts of a proposed action $c$ an be determined by Section $D$ of the NEPA guidance document (DOE 1987b).

Section D (DOE 1987b) lists the type of actions that normally are categorically excluded from further NEPA evaluations or, otherwise, would normally require an Environmental Assessment (EA) or an EIS. If an action is not listed in Section D, then the decision tree (see Figure 11-1) would be used to determine the appropriate level of NEPA evaluation and documentation.

In accordance with Secretary of Energy Notice 15 (SEN-15) and draft DOE orders and guidance, DOE-HQ has the authority to make the decision regarding the correct level of NEPA evaluation and documentation required for a proposed action.

At the Halifurd Site, the DOE has prepared an EIS titled Disposal of Hanford Defense High-Level, Transuranic and Tank Wastes (HDW-EIS) (DOE 1987a). The HDW-EIS considered disposal alternatives for six classes of radioactive wastes:

- DST waste

- SST waste

- Encapsulated radiocesium and radiostrontium 
Figure 11-1. National Environmental Policy Act Determination Process.

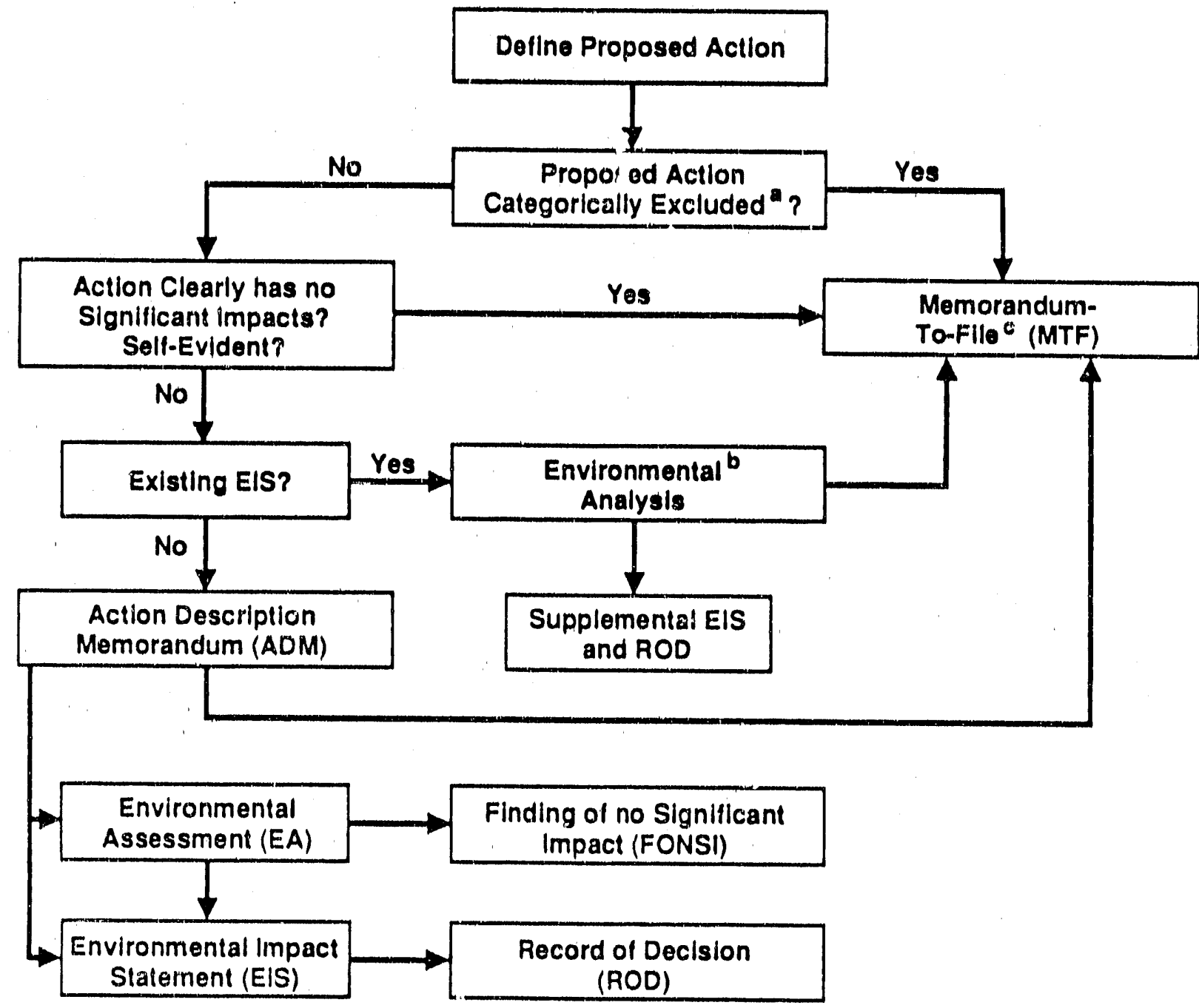

a Section D, 52 FR 47662 (December 15, 1987)

b Section C, 52 FR 47662 (December 15, 1987)

c The MTF will not be acceptable after September 30,1990 . Thereafter, all actions not covered by an existing EIS will be required to undergo an EA or EIS. 
WHC - EP-0348

- Retrievably stored and newly generated TRU solid waste

- Pre-1970 burled, suspect TRU-contaminated solid waste sttes

- TRU-contaminated soll sites.

A preferred alternative was selected for each class of waste and a record of decision was published in April 1988, stating DOE's intent to pursue the preferred alternative.

The DOE has decided to proceed with disposal activities for DST waste, the encapsulated radioceslum and radiostrontium, and the retrievably stored and newly generated TRU solid waste. These disposal activities are described in this document under the corresponding missions, with the retrievably stored and newly generated TRU solid waste described under the solid waste mission (Sections 4, 6, and 7, respectively).

For the remainder of the waste classes (SST, pre-1970 burled, suspect TRU-contaminated solid waste sites, and TRU-contaminated soil sites), DOE has decided to conduct additional development and evaluation before making decistons on final disposal. For SST waste, the additional development and evaluation is described under the corresponding mission (see Section 5). For pre-1970 burled, suspect TRU-contaminated solid waste sites, and TRUcontaminated soli sites, the additional development and evaluation is described in the section on past practice units (PPU) (see Section 9) because these sites were absorbed in the 68 OUs. As further described in Section 9 , six additional OUs include SST waste and four OUs are assoctated with groundwater for a total of 78 OUs to be studied for possible remediation.

The activities associated with liquid effluents (see Section 8) were not discussed in the HDW-EIS. Instead, the plan and schedule for discontinuing contaminant discharges to the soll column was in response to a congressional request in the appropriations bill for FY 1987.

Several major NEPA actions are either underway or planned at the Hanford Site. The eight surplus reactors discussed in Section 10 are the subject of an EIS that is nearly completed. A record of decision on the EIS is planned for publication in FY 1991. A draft of the supplemental HDW-EIS for SST disposal (discussed in Section 5) is proposed for issuance in June 2002 (TriParty Agreement 1 iestone M-09-01). An EIS to address future land and environmental $r r$ coration activities is under discussion at DOE.

The site-wide EIS, which will evaluate the environmental impacts resulting from the operation of the Hanford Site, has been scheduled by DOE-HQ to be completed by FY 1995. A programmatic EIS for waste management activities across the DOE complex is undergoing serfous consideration by DOE. As a result off SEN-15, it is expected that more activities at the Hanford Site will require supplemental EAs or EIS's. 
WHC-EP-0348

Performance assessments are used to calculate environmental impacts of disposal options as required by NEPA. Performance assessments may also be used to determine risk-based remediation levels as part of the CERCLA RI/FS process. Detalls on performance assessment are not identified on the activity networks, but can be found in Section IV of the HWMTP, Supporting Technology Prograins (WHC 1990).

Except for liquid effluents (Section 8) and the D\&D of surplus facilities (Section 10), the activity networks for each mission are inftiated with the decision from the HDW-EIS. For those missions in which dectstons have been deferred in the HDW-EIS, the activity networks show future dectsions compliant with NEPA, RCRA, or CERCLA.

\subsection{CORRECTIVE ACTIVITIES}

Corrective activities are those etther required by environmental and regulatory requirements or those required to fulfill compliance agreements with federal, state, or local regulatory bodies, or a combination of both. These activities are required to ensure regulatory compliance for active facilities at the Hanford Site. Environmental corrective activities can be divided into three major categories: air, water, and solid waste.

Air corrective activities include assessment and upyrade of bulldingexhaust air sampling systems to ensure compliance with the DOF. requirements for the gaseous effiuent management program. Air einission permits are in place at this time for all existing facilities; new permits are expected to be required for several new projects and faclitity modifications as well as for tha addition of 87 new stack effluents, pursuant to state regulations that is $=$ expected to be issued.

There are currently no identified corrective activities in the water category. This is because there are no kriown violations of the clean Water Act of 1977.

Solid waste management activities are more extensive than those for air and water. Obtaining RCRA operating permits for TSD facilities is a major solid waste management activity. The Hanford Site has one permit number under RCRA, with approximately 60 parts (one for each TSD facility). The permit is not expected to be granted until 1995. The Hanford Site TSD facilities are presently under interim status. Other corrective activities include construcition of mixed waste storage and disposal facilities, removal of polychlorinated biphenyl (PCB), installation of liquid effluent monitors, and development of disposal methods for groundwater-monitoring well purge water.

Those corrective activities associated with the solid waste mission (Section 7.0), the mixed waste storage and disposal faciitites and PCB removal, are included in the corresponding activity network. Other corrective activities are not shown in the networks as they are being tracked elsewhere. 
WHC-EP-0348

\subsection{WASTE MINIMIZATION}

An active waste minimization program is under way. Management poltcles and procedures have been implemented defining the requirements and responsiblitties as they apply to individual plants and supporting organizations. The guidelines for developing factlity-specific waste minimization plans have been issued, providing a basis for developing uniform plans at individual plants. The initial Btennial Waste Minimization report (DOE-RL 1988) requitred by the EPA was complled and issued in 1988 with plans already under way for the 1990 report. Training materlal on waste minimization for new employee orlentation and stte-wide waste generator training has been developed and implemented. More detail on waste minimization is provided in the Hanford Site Waste Management Plan (DOE-RL 1989b) under Appendix B, "Summary of Waste Reduction Activities."

Waste minimization is a continuing program with extensive reporting requirements and, therefore, is not shown as a distinct activity in the networks developed for each intsston.

\subsection{LABORATORY SUPPORT}

In February 1988, an assessment of all Hanford Site laboratories was completed. As a result of this assessment, upgrades to existing laboratories were identified, and the need was recognized for a new, low-level analytical laboratory, the Waste Sampling and Characterlzation Factlity (WSCF). Because of expanding work in final waste disposal. ER remedial actions, facility compliance issues, and RCRA permitting and closure activities, both the capabilities and the capacities of the laboratories were found to need upgrading.

The Hanford Site laboratories will transition from research and development, and process control sample analyses, to a position of providing legally defensible environmental sample results. The regulations that now apply to environmental remediation activities at the Hanford Site have increased sampling and analytical requirements. In addition, sampling and analyses protocols have imposed on the laboratories to comply with these regulations. Examples of these new protocols include sample chain-of-custody documentation, increased instrument calibrations, additional standards and blanks processing, sample archiving, enhanced personnel training, detalled quality assurance plans, and a general increased level of documentation.

An upgrade strategy was developed to effectively provide the required laboratory support for Hanford Site programs. The upgrade strategy is to maximize the capabilities and capacities of the 222-S and 325 laboratories; to construct the WSCF to handle nonradioactive, low-level radioactive, and dangerous/hazardous waste samples; to utilize the 325 laboratory for analytical methods development; and to use the Hanford Environmental Health Foundation (HEHF) as a "referee" laboratory. The office of Sample Management (OSM) was established to coordinate programmatic needs with laboratory capabilities to most effectively utilize current capabilities and coordinate the use of offsite laboratories as required. 
WHC-EP. 0348

The WSCF is scheduled to begin operations in January 1992 (Tri-party Agreement milestone M-14). A computer center, the Environmential Data Remedial Tracking System, will also begin operation in January 1992. It will provide records storage for all sample data for both effluent discharges and the assessments for ER remedtal actions. Several support factlittes will be associated with the WSCF complex.

Expanded laboratory hot cells, scheduled to begin operations in June 1994 (Tri-Party Agreement inllestone M-11), will provide analytical capabilities for waste analyses from DSTs, the grout factlittes, SSTs, B Plant and the HWVP. The hot cells will provide at least double the sample throughput capacity from that which is currently avallable at the 222-5 laboratory.

\subsection{ENVIRONMENTAL MONITORING AND CONTROL}

This activity provides support to the general environmental monttoring capabilities for stack discharges, (and other potential alrborne releases), liquid effluent discharges and groundwater. It provides for monitoring trends and assessing the impact of operations to the environment and provides support to operations for effluent disposal facflities, maintenance upgrades, and construction.

The activity provides for RCRA site characterization and site-wide effluent sampling of hazardous waste streams and provides well drllling support necessary to meet RCRA regulatory requitrements. After the wells are drilled, this activity is responsible for required sampling, monttoring, and analysis of data, and associated reports. It is responsibie for assessing any hazardous waste operational impacts upon the environment, recommending corrective actions and implementing those actions required.

An aggressive schedule is being undertaken to install RCRA groundwatermonitoring wells at the rate of 30 in 1990 and 50/yr thereafter unt 11 all land disposal units and SST's are determined to have RCRA compliant monitoring systems (Tri-Party Agreement milestone M-24). After the drilling process is complete, a certain quantity of water must be removed from the well before a representative sample can be obtained from grouridwater. In some locations the groundwater may be contaminated to levels that prevent the disposal of untreated well water. There are no treatment capabilities for contaminated well water, but storage capabilities have been installed while the issue is being evaluated and discussed with the regulatory authorities.

Associated with environmental monitoring and control are three programs being undertaken in response to DOE Orders: Vadose zone monitoring, the groundwater protection management plan, and the seismic monitoring system. Each of these programs are briefly described in the Site-Specific Plan (DOE-RL 1989a).

Because environmental monitoring and control influences several missions, it is not identified as a distinct activity on the networks of the missions. 


\subsection{REFERENCES}

Clean Water Act of 1977, as amended, Publ tc Law 95-217, 92 Stat, 1566, 33 USC 1251.

Comprehensive Environmental Response, Compensation, and Liability Act of 1980, as amended, Publtc Law 96-510, 94 Stat. 2767, 42 USC 9601 et seq.

DOE, 1989a, Comprehensive Environmental Respanse, Compensation, and Liability Act requirements, DOE Order 5400.4, U.S. Department of Energy, Washington, D.C.

DOE, 1989b, Draft Environmental Impact Statement, Decommlssioning of Eight Surplus Production Reactors at the Hanford Site, Richland, Washington, DOE/EIS-0119D, U.S. Department of Energy, Washington, D.C.

DOE, 1988, Radioactive Waste Management, DOE Order 5820.2A, U.S. Department of Energy, Washington, D.C., (September 26, 1988).

DOE, 1987a, Final Environmental Impact Statement--Disposal of Hanford Defense High-Level, Transuranic and Tank Wastes, Hanford Site, Richland, Washington, Vols. 1-5, DOE/EIS-0113, U.S. Department of Energy, Washington, D.C.

DOE, 1987b, NEPA Guidelines, U.S. Department of Energy, Federal Regtster, 52, p 47662 .

DOE-RL, 1989a, Environmental Restoration and Waste Management Site Specific Plan for the Richland Operations office: Detailed Information, DOE-RL-89-10, U.S. Department of Energy -Richland Operations Office, Richlarld, Washington.

DOE-RL, 1989b, Hanford Site Waste Management Plan, DOE-RL 89-32, U.S. Department of Energy-Richland Operations Office, Richland, Washington.

DOE-RL, $1989 \mathrm{c}$, The Hanford Site Environmental Restoration and Waste Management Five-Year P1an Activity Data Sheets, DOE/RL. 89-17, U.S. Department of Energy-Richland Operations Office, Richland, Washington.

DOE-RL, 1988, U.S. Department of Energy-Richland Operations Office 1988 Biennial Waste Minimization Report, DOE/RL. 88-n5, U.S. Department of Energy-Richland Operations office, Richland, Washington.

DOE-RL, 1987, Plan and Schedule to Discontinue Disposal of Contaminated Liquids into the Soil Column at the Hanford Site, (Fiscal Year 1987), unnumbered, U.S. Department of Energy-Rtchland Operations Office, Richland, Washingtor. 
$\mathrm{DOE} / \mathrm{RW}$, 1989, Integrated Data Base, D0E/RW-0006, Revision 5, prepared by Oak Ridge National Laboratory for the U.S. Department of Energy, Washington, D.C.

Ecology, 1989, Dangerous Waste Regulations, Washington Administrative Code (WAC) 173-303, Washington State Department of Ecology, 01ympia, Washington.

Ecology, EPA, and DOE, 1989, Hanford Federal Facility Agreement and Consent Order, Washington State Department of Ecology, Olympia, Washington;

U.S. Environmental Protection Agency, Region 10, Seattle, Washington; and U.S. Department of Energy, Richland, Washington (May 1989).

National Environmental Policy Act of 1969, Public Law 91-190, 83 Stat, 582, 422 USC 4321 et seq.

PNL, 1988, Hazard Ranking System Evaluation of CERCLA Inactive Waste Sites At Hanford, PNL-6456, Pacific Northwest Läboratory, Richland, Washington.

Resource Conservation and Recovery Act of 1976, as amended, Public Law 94-580, 90 Stat. 2795, 42 USC 6901 et seq.

WHC, 1990, Hanford Site Environmental Restoration and Waste Management Technology Plan, WHC-EP-0212-1, Westinghouse Hanford Company, Richland, Washington.

WHC, 1989, Annual Status Report of the Plan and Schedule to Discontinue Disposal of Contaminated Liquids into the Soil Column at the Hanford Site, (Fiscal Year 1989), WHC-EP-0196-2, Westinghouse Hinford Company, Richland, Washington (September 1989). 

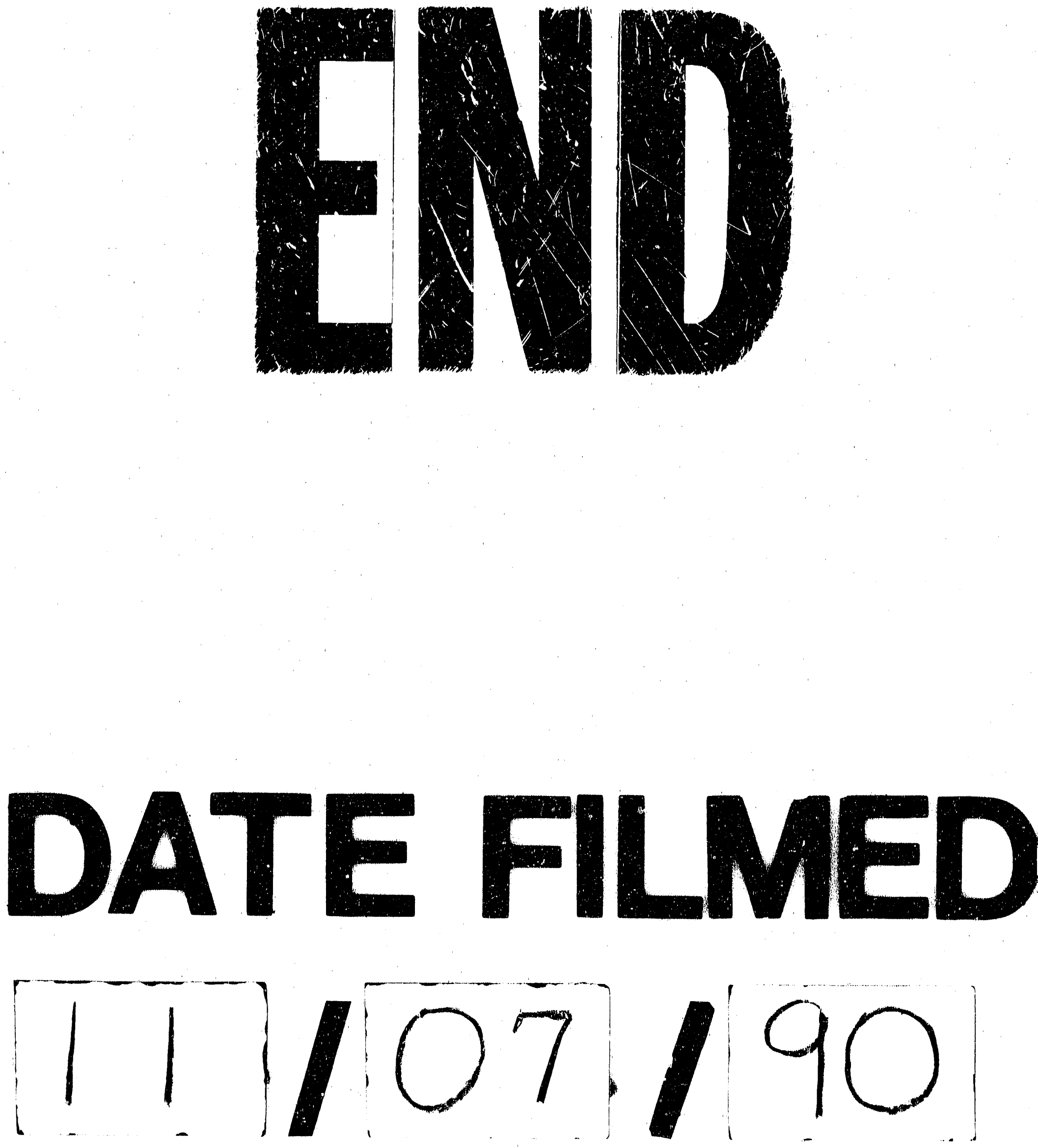
